\title{
Hva kan vi lære av TALIS 2018?
}

Gode relasjoner som grunnlag for læring

Julius K. Björnsson (red.) 
Hva kan vi lære av TALIS 2018? 

Julius Kristjan Björnsson (red.)

\section{Hva kan vi lære av TALIS 2018?}

GODE RELASJONER SOM GRUNNLAG FOR LAERING

CAPPELEN DAMM AKADEMISK 
(C) 2021 Julius Kristjan Björnsson, Sigrid Blömeke, Christian Brandmo, Tone Cecilie Carlsten, Eyvind Elstad, Greta Björk Gudmundsdottir, Kirsti Klette, Trude Nilsen, Ronny Scherer, Inger Throndsen og Dijana Tiplic.

Dette verket omfattes av bestemmelsene i Lov om opphavsretten til åndsverk m.v. av 1961. Verket utgis Open Access under betingelsene i Creative Commons-lisensen CC BY-NC-ND 4.o. Denne lisensen lar andre kopiere, distribuere og spre verket $i$ hvilket som helst medium eller format, under forutsetning av at det oppgis korrekt kreditering og lenke til lisens. Dette kan gjøres på enhver rimelig måte, men uten at det kan forstås slik at lisensgiver bifaller deg eller din bruk av verket. Materialet kan ikke benyttes til kommersielle formål. Dersom du remixer, bearbeider eller bygger på materialet, kan du ikke distribuere det endrede materialet. Lisensvilkår: https://creativecommons.org/ licenses/by-nc-nd/4.o/deed.no

Institutt for lærerutdanning og skoleforskning ved Universitetet i Oslo har bidratt med finansiering av denne boken og Utdanningsdirektoratet har finansiert gjennomføringen av TALIS 2018-studien.

ISBN trykt bok: 978-82-02-71880-o

ISBN PDF: 978-82-02-70898-6

ISBN EPUB: 978-82-02-71996-8

ISBN HTML: 978-82-02-71997-5

ISBN XML: 978-82-02-71998-2

DOI: https://doi.org/10.23865/noasp.123

Dette er en fagfellevurdert antologi. Introduksjonskapittelet er ikke fagfellevurdert.

Omslagsdesign: Cappelen Damm AS

Omslagsbilde: Getty images/smartboyı. Bildet er ikke omfattet av bokens lisens, og kan ikke gjenbrukes uten tillatelse fra Getty images.

Cappelen Damm Akademisk/NOASP

noasp@cappelendamm.no 


\section{Innhold}

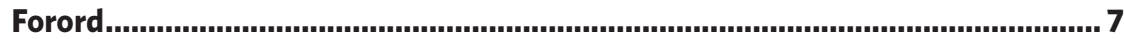

Kapittel 1 Hovedfunn fra TALIS 2018-undersøkelsen....................................9

Tone Cecilie Carlsten, Inger Throndsen \& Julius Kristjan Björnsson

Kapittel 2 Forhold ved skolen som påvirker skolelederens

tilfredshet med jobben

.21

Dijana Tiplic \& Eyvind Elstad

Kapittel 3 Hva fremmer et innovativt miljø i skolen, og hvilken betydning har det for læreres undervisning? .35

Trude Nilsen, Ronny Scherer \& Sigrid Blömeke

Kapittel 4 Hvor godt er lærere forberedt på den digitale hverdagen? .57

Greta Björk Gudmundsdottir \& Julius K. Björnsson

Kapittel 5 Profesjonelle fellesskap på ungdomstrinnet som del av skolens utvikling.

Tone Cecilie Carlsten, Inger Throndsen \& Julius K. Björnsson

Kapittel 6 Nyutdannede læreres opplevelse av læreryrket 107

Christian Brandmo \& Dijana Tiplic

Kapittel 7 Læringsfremmende vurderingspraksis på ungdomstrinnet: Funn fra TALIS 2018 og LISA-prosjektet

Tone Cecilie Carlsten, Inger Throndsen \& Kirsti Klette

Forfatterbiografier 143 



\section{Forord}

Denne boken er den tredje publikasjonen av resultater fra TALIS 2018studien, hvor noen av hovedresultatene fra studien utforskes i mer dybde enn var mulig i de to kortrapportene som ble publisert i desember 2019 og mars 2020.

Boken er et samarbeidsprosjekt mellom forskere fra Institutt for lærerutdanning og skoleforskning (ILS), «Centre for Educational Measurement» (CEMO) og Institutt for spesialpedagogikk (ISP), alle ved Universitetet i Oslo og Nordisk institutt for studier av innovasjon, forskning og utdanning (NIFU). ILS og NIFU gjennomførte selve studien og datainnsamlingen på oppdrag fra Utdanningsdirektoratet. TALIS-studien har vært gjennomført av OECD tre ganger: i 2008, 2013 og sist i 2018. Det spesielle ved denne studien er at den setter søkelyset på lærere på ungdomstrinnet og deres skoleledere, og utforsker deres arbeidsforhold, kompetanseutvikling, veiledning, praksis og skolenes miljø. I 2018 deltok 48 land i studien. Nærmere beskrivelse av studiens organisering kan leses om i kapittel 1 i denne boken.

I undertittelen til boken har vi lagt vekt på at gode relasjoner i skolen kanskje er et av de viktigste elementene i en god skole, noe som fremmer både læring hos elevene og, ikke minst, trivsel og arbeidsglede blant lærere og skoleledere. I mange andre internasjonale studier har norsk skole vist seg å være karakterisert av gode relasjoner, noe som taler for at skolen burde lykkes i å gi sine elever et godt grunnlag for videre utdannelse og arbeid. Men TALIS-studien viser også noen aspekter som kan forbedres vesentlig. Blant annet synes støtten til nye lærere å være manglende i norsk skole, og det trengs bedre kunnskaper om integrering av IKT i undervisningen samt økt kunnskap om undervisning av elever med særlige opplæringsbehov. Noe av dette utforskes i denne boken. En sammenfatning av hovedresultatene fra de to kortrapportene finnes i kapittel 1. 
Det har tatt forholdsvis lang tid å få denne antologien publisert, blant annet på grunn av forsinkelser forårsaket av koronapandemien, men også fordi noen medarbeidere har sluttet og andre har gått av med pensjon. To sentrale medarbeidere må nevnes her, først Inger Throndsen på ILS, som var prosjektleder for TALIS 2018 og gjorde en fenomenal jobb i å gjennomføre studien på beste mulige måte. Tone Cecilie Carlsten fra NIFU jobbet også i prosjektet fra begynnelsen og har deltatt aktivt i både de to kortrapportene og også i denne boken. Disse to medarbeiderne får en kjempestor takk fra redaktøren og uten dem hadde ikke disse resultatene vært mulige. Det er også mange forfattere som har bidratt til denne boken, hovedsakelig fra ILS, og de får også redaktørens største takk for innsatsen. ILS og Utdanningsdirektoratet har også gjort det mulig å gjennomføre denne studien og uten støtten fra begge to hadde ikke dette vært mulig. De får vår største takknemmelighet for sine bidrag.

Oslo i mars 2021

Julius K. Björnsson 


\section{Hovedfunn fra TALIS 2018-undersøkelsen}

\section{Tone Cecilie Carlsten}

Nordisk institutt for studier av innovasjon, forskning og utdanning (NIFU)

\section{Inger Throndsen \& Julius Kristjan Björnsson}

Institutt for lærerutdanning og skoleforskning, Universitetet i Oslo

TALIS - Teaching and Learning International Survey - er OECDs internasjonale undersøkelse om undervisning og læring. Studien er en spørreskjemaundersøkelse rettet mot lærere og skoleledere, der formålet er å belyse viktige sider ved læreres yrkesutøvelse og kompetanseutvikling i tillegg til forhold ved skolen som anses som viktig for elevenes læring.

TALIS 2008 var den første internasjonale undersøkelsen som fokuserte på læreres og skolelederes arbeidssituasjon. Både da og i de to senere undersøkelsene (i 2013 og i 2018) har TALIS vært et verktøy for å undersøke hvordan det er å være lærer og skoleleder på ungdomstrinnet når det gjelder muligheter og begrensninger for kompetanseutvikling, klasse- og skoleledelse, tidsbruk, lærernes undervisningssyn og undervisningspraksis, veiledning, tilbakemelding til lærere og skolens miljø. Dette betyr at lærere og rektorer gjennom sin deltakelse i TALIS-undersøkelsen bidrar med viktige innspill til kunnskapsgrunnlaget for norsk skole.

TALIS ble gjennomført for tredje gang våren 2018, med deltakelse fra til sammen 48 land. Alle de nordiske landene deltok. De to første rundene 
av studien ble gjennomført i 2008 og 2013. Undersøkelsen gjør det mulig å sammenligne forhold i norsk skole med forholdene i andre land. Dette bidrar til å kaste lys over sider ved norsk skole som ikke kommer frem $\mathrm{i}$ en nasjonal undersøkelse. Resultatene fra TALIS 2008 og TALIS 2013 har vært en viktig del av kunnskapsgrunnlaget for myndighetenes politikkutforming i skolesektoren.

TALIS er initiert og organisert av OECD, mens gjennomføringen av undersøkelsen er ivaretatt av et konsortium bestående av International Association for the Evaluation of Educational Achievement (IEA) og Statistics Canada. Studien er utviklet i et samarbeid mellom OECD, det internasjonale konsortiet, forskere og deltakerlandenes utdanningsmyndigheter og lærerorganisasjoner. I Norge er det Utdanningsdirektoratet som har ansvaret for TALIS-undersøkelsen, mens Institutt for lærerutdanning og skoleforskning (ILS) ved Universitetet i Oslo har fătt oppdraget med å gjennomføre datainnsamling, analyse av data og rapportering av resultater. ILS samarbeidet med Nordisk institutt for studier av innovasjon, forskning og utdanning (NIFU) om TALIS 2018. NIFU har hatt hovedansvaret for de to foregående gjennomføringene av TALIS-undersøkelsen.

Norske resultater fra TALIS 2018 er tidligere publisert i to kortrapporter:

- Inger Throndsen, Tone Cecilie Carlsten \& Julius Kristjan Björnsson (2019). TALIS 2018 - Første hovedfunn fra ungdomstrinnet. Institutt for lærerutdanning og skoleforskning, Universitetet i Oslo.

- Tone Cecilie Carlsten, Inger Throndsen \& Julius Kristjan Björnsson (2020). TALIS 2018 - Flere hovedfunn fra ungdomstrinnet. Institutt for lærerutdanning og skoleforskning, Universitetet i Oslo.

I disse rapportene gjøres det også rede for arbeidet med spørreskjemaene, utvalg og gjennomføring.

\section{Sammenfatning av hovedfunn}

Utgangspunktet for OECDs definisjon av profesjonalitet i skolen kan visualiseres ved hjelp av figur 1 (OECD, 2020). Som det går frem av 


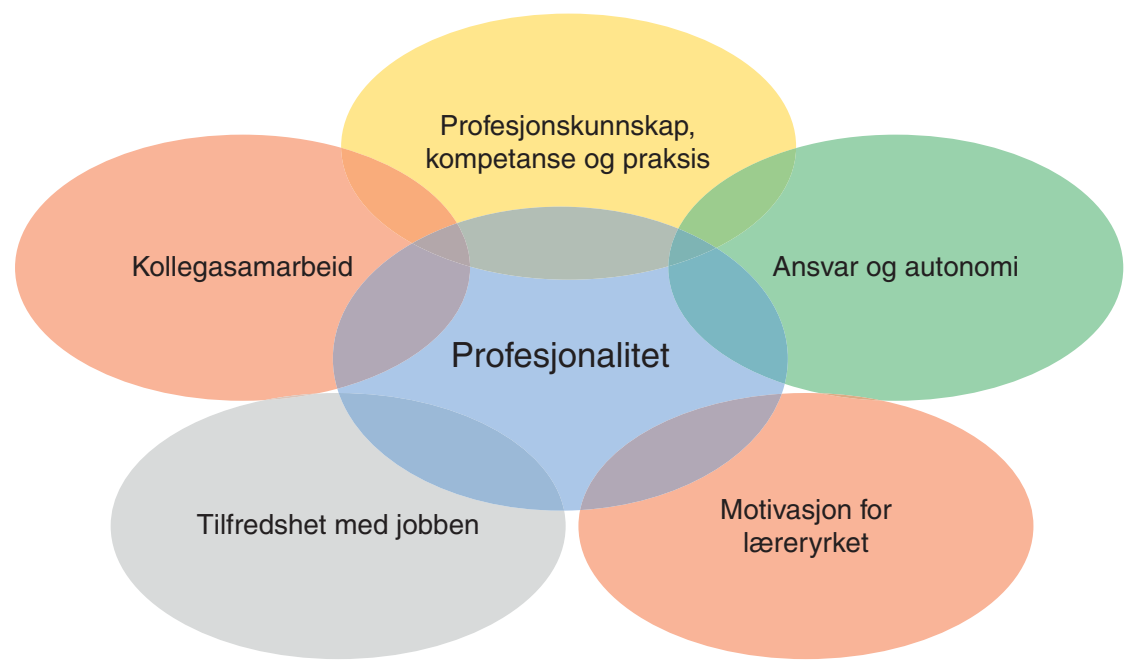

Figur 1 Fem hovedområder i TALIS 2018-undersøkelsen (oversatt og justert fra OECD, 2020).

figuren, er profesjonsbegrepet i TALIS inndelt i fem ulike områder. I presentasjonen av resultatene fra TALIS 2018 tas det utgangspunkt i denne inndelingen.

\section{Område 1: Profesjonskunnskap, kompetanse og praksis}

Gode relasjoner og høy trivsel. TALIS 2018 viser at norske ungdomsskoler kjennetegnes ved gode personlige relasjoner. De aller fleste lærerne er enige $\mathrm{i}$ at lærere og elever vanligvis kommer godt overens, og at lærerne ved skolen har tillit til hverandre. Ni av ti lærere er tilfredse med arbeidsplassen sin, og kun én av ti ville byttet til en annen skole dersom det var mulig. Dette stemmer godt overens med resultatene fra tidligere runder av TALIS-undersøkelsen (Caspersen et al., 2014; Vibe et al., 2009).

God klasseledelse. Ifølge TALIS 2018 er det god arbeidsro i norske klasserom. For eksempel svarer lærerne at i gjennomsnitt går 82 \% av en typisk undervisningsøkt med til undervisning og læring, mens $10 \%$ av 
tiden går til å holde ro i klasserommet. Dette skiller seg fra situasjonen i flere andre land hvor utviklingen har gått i motsatt retning. Ifølge norske ungdomsskolelærere kommer også undervisningen raskt i gang når timen begynner. I TALIS 2008 svarte over halvparten av lærerne at det tar ganske lang tid å få roet ned elevene når timen begynner (Vibe et al., 2009). Til sammenligning rapporterer kun $17 \%$ av lærerne om at dette er et problem i TALIS 2018. Norge er det landet som kan vise til størst positiv endring på dette området.

Mot en mer loeringsfremmende vurderingspraksis. Hele åtte av ti ungdomsskolelærere svarer at de ofte/alltid gir skriftlig tilbakemelding på elevenes arbeider i tillegg til å sette karakter. Gode skriftlige tilbakemeldinger har en viktig funksjon ved at de kan gi elevene bedre innsikt i hvor de står faglig, og hva de bør vektlegge i det videre læringsarbeidet. I TALIS 2018 er Norge blant landene hvor en slik vurderingspraksis forekommer hyppigst. Det ble også registrert at lærerne i større grad enn tidligere involverer elevene i vurderingsarbeidet.

Svak oppfølging av nyutdannede loerere. Det funnet fra TALIS 2018 som gir størst grunn til bekymring, er knyttet til skolens oppfølging av nyutdannede lærere. Kun hver fjerde lærer med fem års erfaring eller mindre svarer at de som nyutdannet deltok i et introduksjonsprogram som nytilsatt i skolen, og kun hver sjette nyutdannete lærer har en veileder til å støtte seg. Overgangen fra studenttilværelsen til utøvelse av lærerjobben oppleves av mange som krevende. Ifølge internasjonal forskning er «turnover» spesielt høy blant nyutdannede lærere, og opplevelsen av manglende støtte trekkes ofte frem som hovedårsaken til at de forlater yrket.

Rektorene har behov for bedre kunnskap om pedagogisk ledelse. Hver femte rektor svarer at de har «stort behov» for å bedre sin kompetanse innen lokalt læreplanarbeid. Omtrent like mange svarer at de har «stort behov» for bedre kunnskap om observasjon av undervisningen, hvordan de kan fremme samarbeid mellom lærerne samt å kunne gi konstruktive tilbakemeldinger.

Lorerne har behov for bedre kunnskap om bruk av teknologi. Ifølge TALIS 2018 melder hver femte lærer om «stort behov» for bedre kunnskap om å integrere IKT i undervisningen. En helhetlig satsing på IKT i 
skolen dreier seg ikke bare om innkjøp og drift av teknologi, men også at det etableres et system for opplæring og faglig støtte rettet mot pedagogisk bruk. For å lykkes med integrering av digitale ferdigheter i undervisningen, er det ikke tilstrekkelig at IKT-utstyr er på plass. Det kreves også at lærerne besitter kunnskap om hvordan teknologi kan tas i bruk på en hensiktsmessig måte.

Lorerne har behov for bedre kunnskap om undervisning av elever med sarlige opploeringsbehov. I TALIS 2018 svarer hver sjette lærer at de har «stort behov» for å bedre sin kunnskap om undervisning av elever med særlige opplæringsbehov. Denne situasjonen understrekes ytterligere ved at nærmere hver femte rektor ser på mangel på lærere med slik kompetanse som en faktor som «i stor grad» hindrer skolen i å gi god undervisning. Behovet for økt kunnskap på dette feltet ble også fremhevet i rapporten fra TALIS 2008 (Vibe et al., 2009).

\section{Område 2: Kollegasamarbeid}

Et ungdomstrinn preget av sterk samarbeidskultur. Hele $95 \%$ av norske lærere er enige i at det er en kultur for å støtte hverandre og samarbeide ved skolen deres. Dette bekrefter inntrykket av et godt samarbeidsklima i norsk ungdomsskole sett i forhold til andre land, noe som har holdt seg jevnt siden den første TALIS-undersøkelsen i 2008. Samarbeidet er i første rekke preget av praktiske og koordinerende aktiviteter, slik som deltakelse på teammøter, utveksling av undervisningsmateriell og diskusjon om utviklingen til bestemte elever. Det har skjedd en positiv utvikling i Norge når det gjelder omfang av samarbeidsaktiviteter som å diskutere utviklingen til bestemte elever og å samarbeide med andre lærere ved skolen for å sikre felles standarder for elevvurdering. Fra TALIS 2013 har det også vært en økning i antall ungdomsskolelærere som har deltatt i faglig kompetanseutvikling sammen med kolleger.

Svak tilbakemeldingskultur på ungdomstrinnet. Et hovedfunn fra TALIS 2008 og 2013 handlet om at norsk skole var preget av en svak kultur for faglige tilbakemeldinger til lærerne, men at det var en positiv utvikling i perioden. TALIS 2018 viser at en noe større andel lærere med lang erfaring (dvs. de som har jobbet mer enn 5 år) har mottatt 
tilbakemelding på jobben de utfører enn de som har jobbet 5 år eller mindre. Selv om forskjellen ved første øyekast ikke er veldig stor (89\% versus $84 \%$ ), er dette et noe uventet resultat, da en skulle forvente at uerfarne lærere har langt større behov for støtte i utførelse av jobben enn erfarne lærere har.

\section{Område 3: Ansvar og autonomi}

Lorere opplever stor grad av kontroll i jobben. Norske ungdomsskolelærere oppgir at de i stor grad opplever å ha kontroll over egne kjerneoppgaver. Hele $97 \%$ mener de har kontroll over valg av fagstoff i planlegging og gjennomføring av undervisningen. Hele $98 \%$ oppgir at de har kontroll over valg av metoder, mens $97 \%$ har kontroll over vurdering av elevenes læring. Videre oppgir $94 \%$ at de har kontroll over måter å irettesette elevene på, og en like stor andel mener de selv kan bestemme hvor mye lekser som skal gis.

Norsk skole har en felles ansvarsforståelse. I alt $86 \%$ av norske lærere oppfatter at skolen gir personalet muligheter til å ta del i beslutninger som angår skolen, og 80 \% av lærerne mener at det hos dem finnes en kultur for delt ansvar i saker som angår skolen. TALIS 2018 viser også at $80 \%$ av norske lærere mener de ansatte ved skolen deler et felles sett av oppfatninger om undervisning og læring, mens $84 \%$ av skolelederne mener det samme. Sammenlignet med svar fra lærere i andre nordiske land er de norske lærerne mer enstemmige i at det er en slik felles forståelse. Det er noe mindre enighet blant norske lærere og skoleledere om ansatte ved egen skole håndhever regler for elevatferd likt for alle elevene ved skolen.

\section{Område 4: Tilfredshet med jobben}

Lorere føler ikke at yrket er verdsatt $i$ samfunnet, og mange opplever stress $i$ jobben. Kun hver tredje norske ungdomsskolelærer er enig i at lærerprofesjonen er verdsatt i samfunnet, og kun $24 \%$ av lærerne er enige i at lærere blir verdsatt i media. Stress i jobben er betydelig mindre blant eldre lærere enn hos de yngre. Det er først og fremst mengden administrativt arbeid 
og arbeidet med elevvurdering som er kilder til stress i jobben. Også blant rektorene er mengden administrativt arbeid det som i størst grad oppleves som kilde til stress. Til tross for dette gir hele $95 \%$ av lærerne uttrykk for at de liker å jobbe ved skolen sin, 93 \% sier de er fornøyde med jobben og $73 \%$ at de ville valgt læreryrket på nytt. Det er kun 8 \% som svarer at de angrer på at de ble lærere.

\section{Område 5: Motivasjon for læreryrket}

Lorere og skoleledere er fornøyde med jobben, men mange vurderer å slutte. Selv om norske ungdomsskolelærere er svært positive til jobben sin og er fornøyde med hvordan de utfører jobben, er det grunn til å merke seg at hver sjuende lærer under 35 år og hver femte lærer i alderen 35-39 år ser for seg at de vil jobbe som lærer i maksimum fem år til. Det er også bekymringsfullt at nærmere halvparten av norske skoleledere under 45 år ønsker å fortsette i jobben som rektor kun inntil fem år til, mens dette gjelder for hver tredje rektor i aldersgruppen 45-54 år.

\section{Nasjonale tilleggsspørsmål 2018: Læreres mestringsevne}

TALIS 2013 viste at norske ungdomsskolelærere syntes å ha svak tiltro til at de klarte å motivere elever som viste svak interesse for skolearbeidet (Caspersen et al., 2014). Det var urovekkende at kun $6 \%$ av lærerne mente de «i stor grad» klarte dette, sammenlignet med 23 \% i Danmark og $27 \%$ for gjennomsnittet av alle TALIS-landene. Forskjellen var også stor dersom om man inkluderte andelen som hadde svart «i nokså stor grad». Da kom andelen i Norge opp i 39 \%, mot 82 \% i Danmark og 71 \% i det internasjonale gjennomsnittet. Det var også verdt å merke seg at over $60 \%$ av norske lærere mente at de bare «til en viss grad» klarer å motivere elever som viste svak interesse for skolearbeidet.

I forbindelse med evalueringen av virkemidlene i den nasjonale satsingen «Ungdomstrinn i utvikling», ble tilsvarende spørsmål stilt til norske ungdomsskolelærere i 2014 (Markussen et al., 2015). Her svarte bare $7 \%$ at de «i svært stor grad» klarte å motivere elever som viser svak 
interesse for skolearbeidet, det vil si ganske godt samsvar med resultatene fra TALIS 2013.

I TALIS 2018 er ikke svarene mer optimistiske. Kun $4 \%$ av lærerne svarte at de «i stor grad» klarer å motivere elever som viser svak interesse for skolearbeidet, mens 28 \% svarte at de «i nokså stor grad klarer dette». Det er med andre ord hele $68 \%$ av norske ungdomsskolelærere som mener at de «aldri» eller «i liten grad» klarer å motivere elever som viser svak interesse for skolearbeidet.

På bakgrunn av de oppsiktsvekkende funnene fra TALIS 2013, som var vanskelige å forklare grunnet mangel på utdypning, la vi til noen ekstra nasjonale spørsmål om dette tema i TALIS 2018. Vi spurte blant annet om lærerne mente de hadde behov for kompetanseutvikling med tanke på å kunne motivere elever som viser svak interesse for skolearbeidet. Her svarte hele $82 \%$ at de «i noen grad» eller «i stor grad» hadde behov for slik faglig utvikling. Lærerne ble også spurt om tilbakemeldinger de hadde fått i løpet av de siste 12 månedene hadde ført til en positiv endring når gjaldt å motivere elever som viser svak interesse for skolearbeidet. I alt $33 \%$ svarte ja på dette spørsmålet.

Lærerne ble også spurt om hvor ofte de diskuterer undervisningsmetoder som er egnet til å motivere elever som viser svak interesse for skolearbeidet. Her svarte $18 \%$ at dette ble diskutert hyppigere enn en gang i uken. $29 \%$ svarte at de diskuterte dette temaet 1-3 ganger i uken, mens $18 \%$ svarte at de diskuterte dette 5-10 ganger i året. $17 \%$ av lærerne diskuterte dette 2-4 ganger i året, mens 4 \% svarte at de aldri diskuterte slike undervisningsmetoder.

I bokkapittelet «Hvorfor er det vanskelig for ungdomsskolelærere å engasjere elevene sine?» (Carlsten et al., 2019) ble resultatene fra TALIS 2013 diskutert. Det ble konkludert med at det var grunn til feste lit til resultatene selv med et kritisk blikk på dataene. Basert på internasjonal forskning ble det hevdet at det er grunn til å tro at dersom lærere har begrenset tiltro til at de mestrer å skape engasjement blant elevene, vil det kunne virke negativt inn på elevenes engasjement og læring. Analysene fra TALIS 2018 viser at det fortsatt er grunn til bekymring når det gjelder å styrke lærernes tiltro til egen undervisning for elever som viser svak interesse for skolearbeidet. 


\section{Sammenfatning av bokens kapitler}

Kapittel 2 er skrevet av Dijana Tiplic og Eyvind Elstad og handler om skoleledelse og kompetanseutvikling. Her utforsker de hvilke faktorer som forklarer norske skolelederes profesjonelle og individuelle jobbtilfredshet. De finner at innovasjonsstøtte og stress er statistisk relatert til skolelederens jobbtilfredshet, men at rektors undervisningsstøtte ikke er relatert til jobbtilfredshet med skolen og at rektorers opplevelse av stress er negativt relatert til flere positivt ladede egenskaper ved skolens organisasjon (innovasjonsstøtte, undervisningsstøtte og jobbtilfredshet med skolen). Mulige tolkninger er at innovasjonsstøtte bidrar til jobbtilfredshet med skolen, mens stress kan oppfattes som en hemmende faktor i rektorers arbeid. Implikasjoner for praksis og videre forskning diskuteres.

I kapittel 3 spør Trude Nilsen, Sigrid Blömeke og Ronny Scherer om innovasjon i skolen er viktig for en bærekraftig utvikling, for at elever skal klare seg i morgendagens samfunn og som et kriterium for skolens tilpasningsevne til samfunnsendringer. Det foreligger lite forskning på innovasjon i skolen. Ved 2-nivå (lærere og skoler) SEM-analyser undersøkte de effekten av distribuert ledelse på innovasjon, og effekten av innovasjon på læreres undervisningskvalitet. Funnene viser: 1) at skoler som har en distribuert ledelse, hvor alle parter får mulighet til å påvirke skolens beslutninger, er mer innovative enn skoler som ikke har distribuert ledelse, og 2) at skoler som er innovative har lærere som i større grad gir elevene stimulerende undervisning (ved for eksempel å utfordre elevene til kritisk tenkning og problemløsning). Slike skoler gir også en mer inkluderende undervisning enn ved mindre innovative skoler.

Med andre ord har distribuert ledelse en positiv effekt på innovasjon, som igjen har en positiv effekt på læreres undervisningskvalitet. Funnene viser hvordan skoleledelsen kan bidra til innovasjon, og hvordan innovasjon kan frembringe den undervisningen elevene trenger for å bli best mulig rustet til fremtidens utfordringer.

Kapittel 4 er skrevet av Greta Gudmundsdottir og Julius K. Björnsson. Her stiller de spørsmålet om hvor godt lærerne er forberedt på en digital hverdag. De introduserer kort et rammeverk for profesjonsfaglig digital kompetanse (PFDK) og andre viktige bakgrunnsdokumenter som viser funn fra tidligere kartlegginger om IKT i lærerutdanningen. Deretter 
presenteres funn om læreres erfaringer med IKT knyttet til skolemiljø og hvordan de opplever støtte fra kollegiet til å bruke IKT i sin profesjonsutøvelse. Kapittelet tar også for seg hvem som deltar i faglig og profesjonell utvikling knyttet til IKT, og læreres opplevde læringsutbytte av disse tiltakene. Nordiske og internasjonale data sammenlignes, sammen med funn fra TALIS 2018 med tidligere funn fra TALIS-undersøkelser. Fra dette trekker de konklusjoner om hvordan lærerne er forberedt på en digital hverdag og hva lærerutdanningen kan gjøre for å styrke PFDK ytterligere.

I kapittel 5 skriver Tone Cecilie Carlsten, Inger Throndsen og Julius K. Bjørnsson om profesjonelt samarbeid i læreryrket og hvordan dette relateres til skoleutvikling på ungdomstrinnet. Analysene tar spesielt for seg hvordan lærere på ungdomstrinnet samarbeider på ulike måter, og hvordan skoleledere følger opp dette arbeidet for å legge til rette for lærernes profesjonsutvikling. Funn blir satt i sammenheng med norske funn fra TALIS 2008 og 2013 for å se nærmere på de lange linjene i skolen. Kapittelet avsluttes med noen implikasjoner for praksis og videre forskning.

I kapittel 6 presenterer Christian Brandmo og Dijana Tiplic TALISanalyser om nyutdannede læreres trivsel og jobbmotivasjon. I lys av debatten det siste tiåret om mangelen på kvalifiserte lærere, undersøker de hvilke faktorer som predikerer nyutdannede læreres opplevelse av jobbtilfredshet, stress og tanker om å slutte i jobben. Kapittelet viser blant annet til forskjeller mellom kvinnelige og mannlige lærere når det gjelder tilfredshet og stress, og ulikheter mellom nyutdannede og erfarne lærere når det gjelder tilfredshet med yrke og skole. Brandmo og Diplic presenterer også funn om tilknytning til og støtte fra organisasjonen, og peker på implikasjoner for ledere og beslutningstakere.

Kapittel 7 av Tone Cecilie Carlsten, Inger Throndsen og Kirsti Klette sammenstiller resultater fra LISA-studien og TALIS-undersøkelsen, og ser nærmere på hvordan de to studiene komplementerer hverandre. Her analyseres data fra TALIS 2018 som omhandler lærernes opplevelse av egen undervisningspraksis, spesielt hvordan lærerne kontrollerer at elevene forstår nye emner og hvordan de gir tilbakemeldinger til elevene på skriftlige oppgaver. Funn blir satt inn i et nordisk perspektiv som rammer inn lærernes opplevelse av kontroll over egen undervisningspraksis. 
Resultatene blir deretter diskutert opp mot hovedfunn fra LISA-studien. I denne undersøkelsen er det samlet inn omfattende videomateriale fra klasserom. Testresultater fra samme informantgruppe gir muligheter for å undersøke sammenhengen mellom undervisning og elevprestasjoner i matematikk og lesing på ungdomstrinnet. Kapittelet avsluttes med noen implikasjoner for praksis og videre forskning.

\section{Referanser}

Carlsten, T. C., Throndsen, I. \& Björnsson, J. K. (2020). TALIS 2018 - Flere hovedfunn fra ungdomstrinnet (Rapport, Universitetet i Oslo). https://www.uv.uio. no/ils/forskning/prosjekter/talis/filer/talis_2018_kortrapport2_final-\%28002\%29. pdf

Carlsten, T. C., Aamodt, P. O. \& Caspersen, J. (2019). Hvorfor er det vanskelig for ungdomsskolelærere å engasjere elevene sine? I J. Caspersen \& S. Wendelborg (Red.), Skolen vår! (s. 84-103). Gyldendal Akademisk.

Caspersen, J., Aamodt, P. O., Vibe, N. \& Carlsten, T. C. (2014). Kompetanse og praksis blant norske loerere: Resultater fra TALIS-undersøkelsen i 2013 (NIFU-rapport 2014:41). https://www.nifu.no/publications/1173469/

Markussen, E., Carlsten, T. C., Seland, I. \& Sjaastad, J. (2015). Fra politisk visjon til virkeligheten i klasserommet: Evaluering av virkemidlene i Ungdomstrinn i utvikling. Delrapport 2 (NIFU-rapport 2015:27). https://www.nifu.no/ publications/1330334/

OECD. (2020). TALIS 2018 Results (Vol. II). Teachers as Valued Professionals. OECD. https://www.oecd.org/publications/talis-2018-results-volume-ii-19cfo8df-en.htm Throndsen, I., Carlsten, T. C., Björnsson, J. K. (2019). TALIS 2018 - Første hovedfunn fra ungdomstrinnet. Institutt for lærerutdanning og skoleforskning, Universitetet i Oslo.

Vibe, Nils; Aamodt, Per Olaf; Carlsten, Tone Cecilie (2009). A vore ungdomsskoleloerer i Norge: Resultater fra OECDs internasjonale studie av undervisning og loering (TALIS) (NIFU-rapport 2009:23). http://hdl.handle. net/11250/2601320 



\title{
Forhold ved skolen som påvirker skolelederens tilfredshet med jobben
}

\section{Dijana Tiplic \& Eyvind Elstad \\ Institutt for lærerutdanning og skoleforskning, Universitetet i Oslo}

\begin{abstract}
School aspects that influence the principals' job-satisfaction
This article aims to analyze how different school relations can influence principals' job satisfaction. Our analysis is based on TALIS survey data from 162 Norwegian principals. We have used Structural Equation Modelling (SEM) to analyze statistical relations between several potential explaining variables and principals' professional and individual job satisfaction. The main findings show that innovation support and stress are statistically related to principals' job satisfaction with school. On the other hand, principals' teaching support is not related to their job satisfaction with school. In addition, principals' perception of stress is negatively related to several positively charged characteristics of school as an organization (innovation support, teaching support, and job satisfaction with school). Possible interpretations of the findings are that innovation support contributes to job satisfaction with school but that stress can be perceived as an inhibitory factor in principals' work. This article focuses on stress that involves a work overload from following up on teachers' professional development, having too much administrative work, as well as having extra work due to staff absence. This stress is primarily related to a connection between principals' working capacity and their ambitions to execute their leadership goals. Implications for practice and further research are discussed.
\end{abstract}

Keywords: school principals, job satisfaction, innovation support, instructional leadership

Sitering av denne artikkelen: Tiplic, D. \& Elstad, E. (2021). Forhold ved skolen som påvirker skolelederens tilfredshet med jobben. I J. K. Björnsson (Red.), Hva kan vi laere av TALIS 2018? Gode relasjoner som grunnlag for loring (Kap. 2, s. 21-33). Cappelen Damm Akademisk. https://doi.org/10.23865/noasp.123.ch2 Lisens: CC BY-NC-ND 4.0. 


\section{Introduksjon}

Skolen er en viktig samfunnsinstitusjon som skal forberede unge mennesker på oppgaver som venter dem senere i livet. Skolesektoren omfatter interaksjon mellom ulike institusjoner. På den ene siden finnes det en hierarkisk styringskjede fra nasjonale og regionale myndigheter og til skolen og dens tre hierarkiske nivåer (skoleledelse, lærere og elever). Samtidig kan situasjonslogikken i styringskjeden også åpne opp for kompleks strategisk interaksjon mellom ulike aktører (Elstad, 2009). Videre har det skjedd styringsendringer over tid med tendenser til mer fokus på å innfri ytre forventninger gjennom resultatstyring, økonomiske insentiver og fleksibilitet i skolen (Møller, 2019). Slike tendenser har betydning for utøvelsen av rektorrollen. Blant annet gjelder dette oppgaver som handler om å innfri administrative forventninger og forventninger fra foreldre. På den andre siden har aktørene innad i skolen stor autonomi med muligheter for blant annet lokalt strategi- og utviklingsarbeid. I sum bidrar disse mangfoldige situasjonsbetingelsene til at rektorrollen kan være krevende å håndtere.

I arbeidet med å realisere den gode skole har skoleledere i oppgave å lede lærernes arbeid med å legge til rette for at elever skal lære faglig innhold, samt oppleve trivsel, personlig vekst m.v. I dette kapitlet presenterer vi resultater fra en analyse hvor formålet er å forstå bedre hvordan ulike forhold ved skolen påvirker skolelederens tilfredshet med jobben. Den avhengige variabelen i analysen er skolelederes jobbtilfredshet. Med jobbtilfredshet menes her tilfredshet som har sammenheng med den skoleinterne virksomheten. Tilfredshet som stammer fra anerkjennelse fra personer utenfor skolen (for eksempel skoleeiere), inngår ikke i det begrepet «jobbtilfredshet» vi her anvender. De uavhengige variablene som inngår i teorirammeverket, er undervisningsstøtte, innovasjonsstøtte og stress. Disse begrepene er valgt som komponenter i teorirammen fordi de antas å ha sammenheng med både hemmende og fremmende faktorer i rektorers arbeidssituasjon. I denne studien tar vi derfor utgangspunkt $i$ en teoriramme som innbefatter noen utvalgte aspekter ved rektorers arbeidssituasjon som antas å være relatert til rektorers jobbtilfredshet: stress som begrensende faktor (Demir, 2018), og overskuddsfenomener som det å bidra til innovasjon (Lee et al., 2014) og gi støtte til undervisning 
(Liu et al., 2020). Den metodiske tilnærmingen som er valgt, gjør det også mulig å estimere styrker i statistiske relasjoner mellom de uavhengige variablene som inngår i teorirammen.

Faktorer som påvirker skolelederens jobbtilfredshet med skolen, er viktige å studere fordi det hevdes å være en gryende rekrutteringskrise til rektoryrket: Mange skoler finner det krevende å få ansatt nye rektorer (Bergsli, 2020). Ofte er det få søkere, særlig i stillinger som lyses ut i små kommuner. En sentral utfordring er å få nyansatte rektorer til å trives i sin jobb (Bjørnset \& Kindt, 2019). «Turnover» blant rektorer er i liten grad blitt systematisk undersøkt, men noen studier indikerer at høy «turnover» forekommer (Silva, 2011; Vedvik, 2020; Aass, 2014). Bekymringene for at skoler vil mangle gode ledere, øker, både i Norge og andre land. Svikt i den potensielle rekrutteringsbasen kan derfor på sikt ramme både pedagogisk kvalitet og elevers læring i skolen (Bergsli, 2020). Valget av studiens avhengige variabel kan derfor begrunnes i en reell bekymring for konsekvenser av manglende jobbtilfredshet for personer som arbeider som rektor.

\section{Teoretisk tilnærming}

Studiet av betydningen av jobbtilfredshet i arbeidslivet kan spores tilbake til studier i arbeids- og organisasjonspsykologi fra 1920- og 1930-tallet (f.eks. Houser, 1927) der jobbtilfredshet ble forstått som enhver kombinasjon av indre og ytre forhold som gjør en person i stand til å si at «jeg er tilfreds med min jobb» (Hoppock, 1935). Senere har begrepet jobbtilfredshet blitt stykket opp i mindre og avgrensede komponenter (Brayfield \& Rothe, 1951; Locke, 1969), eksempelvis intern og ekstern jobbtilfredshet (Hackman \& Oldham, 1980). Denne studien avgrenser seg til intern jobbtilfredshet.

Studier av sammenhenger mellom uavhengige og avhengige variabler vil måtte forutsette kausale prosesser i en eller annen forstand. I valget av teoretiske komponenter i teorirammen velger vi potensielle uavhengige faktorer som kan begrunnes i tidligere forskning. Det ligger imidlertid utenfor denne studiens ambisjonsnivå å kunne si noe om kausalretningen på relasjonene som inngår i den teoretiske modellen. Vi bemerker 
at kausalretningen kan gå flere veier: skolelederes jobbtilfredshet med skolen kan for eksempel tenkes å påvirke hvordan skoleledere oppfatter at de vil kunne påvirke undervisningen gjennom sitt lederskap (og motsatt). Selv om vi fokuserer på faktorer som antas å påvirke rektorers jobbtilfredshet med skolen, understreker vi meget sterkt at vi ikke har bevis for kausalretning i de relasjoner som estimeres. De skoleinterne faktorene som vi legger vekt på som forklaringsfaktorer, er som nevnt en variant av det som kalles undervisningsstøtte («instructional leadership», Blase \& Blase, 2000; Hallinger, 2010), internt stress (Bjørnset \& Kindt, 2019) og grad av innovasjonsstøtte (Dee et al., 2002; Siegel \& Kaemmerer, 1978). Den metodiske tilnærmingen setter noen begrensinger i hvor mange uavhengige faktorer som kan inngå i en estimering av styrkeforhold mellom variabler. For at ikke analysen skal omfatte for mange faktorer, fokuserer vi her på skoleinterne aspekter ved rektorers jobbtilfredshet.

Skolelederes undervisningsstøtte har vist seg å være en betydningsfull ledelsesform i den forstand at andre studier har vist at det er en klart empirisk relasjon mellom undervisningsledelse på en skole og elevers læringsresultater (Robinson et al., 2008). Av denne grunnen har skolelederes undervisningsstøtte blitt vektlagt i en norsk politikk-kontekst: skoleledere forventes å følge opp læreres undervisning gjennom tilbakemeldinger fra elever og observasjoner (Lejonberg et al., 2018). Vi finner derfor at det er interessant å utforske empiriske relasjoner mellom undervisningsstøtte og andre variabler i denne studien. I denne sammenhengen forstår vi undervisningsstøtte som skolelederens intensjon om å støtte opp om samarbeid mellom lærere med tanke på forbedringer av undervisning, at skolelederen jobber for at lærere tar ansvar for forbedringer, samt tar ansvar for elevenes læring. Med andre ord er undervisningsstøtte å forstå som støttende lederskap overfor lærere.

Undervisningsstøtte må antas å være relatert til innovasjonsstøtte i skolens organisasjon: daglig drift og innovasjon kan ikke ses på som atskilte virksomheter. Med innovasjonsstøtte menes her at skolen raskt ser behovet for å gjøre ting på en annen måte, er rask til å reagere når det er nødvendig å foreta endringer, at nye ideer blir lett akseptert, og at det er lett å få hjelp når man ber om det. Relasjonen mellom rektors 
rolleutøvelse og kultur for læring i skolens organisasjon er godt dokumentert i andre lands skolekontekster (eksempelvis Engels et al., 20o8; Moolenaar et al., 2010, 2011, 2014; Waldron \& McLeskey, 2010). I denne studien antar vi at det er en positiv relasjon mellom innovasjonsstøtte og jobbtilfredshet.

Når det gjelder stress, påpeker tidligere forskning at for mye stress kan virke hemmende på både jobbtilfredshet og ytelse (Chaplain, 2001). Her fokuseres det på relasjoner mellom skoleleders opplevelse av skoleinternt stress (å ha for mye arbeid med å følge opp lærernes faglige og profesjonelle utvikling, å ha for mye administrativt arbeid å gjøre, å ha ekstraoppgaver på grunn av fravær i personalet) med andre variabler. Her antar vi at stress er en faktor som er negativt relatert til både jobbtilfredshet, undervisningsstøtte og innovasjonsstøtte. Med andre ord antar vi en negativ relasjon mellom stress og jobbtilfredshet. Vi antar også at det er en negativ relasjon mellom stress og innovasjonsstøtte, samt stress og undervisningsstøtte. Stress formodes å være en hemmende faktor i skolelederes arbeidssituasjon. Figur 1 oppsummerer antakelsene vi baserer vår studie på.

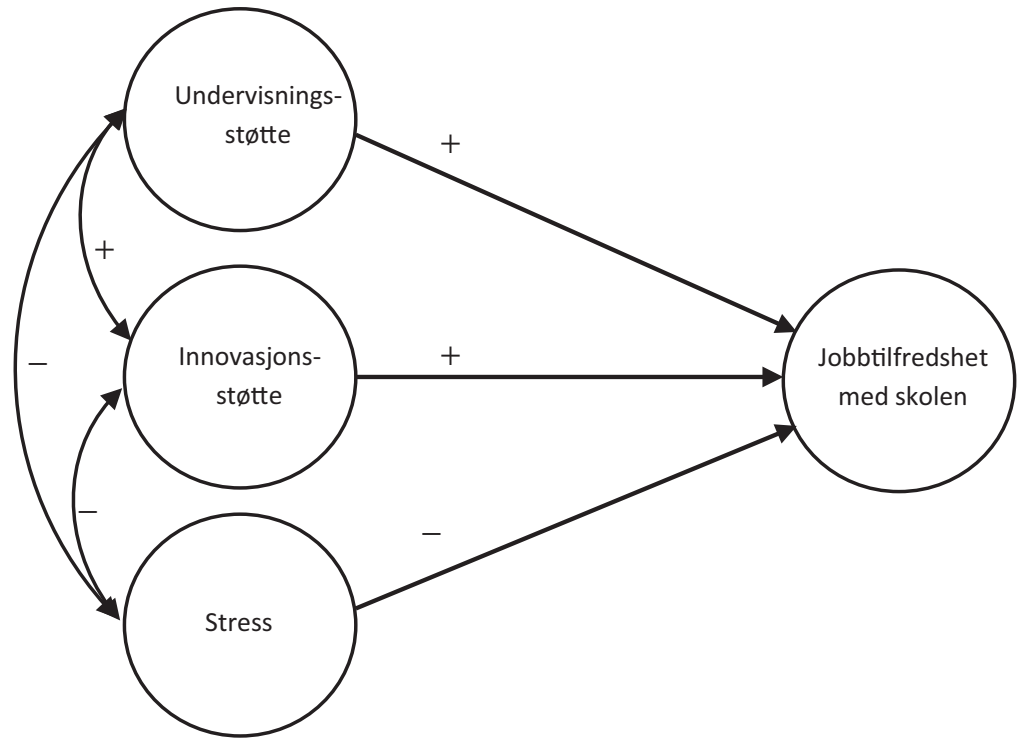

Figur 1 Teoretisk begrunnede forventninger om relasjoner mellom rektorers jobbtilfredshet med skolen og undervisningsstøtte, innovasjonsstøtte og stress. 


\section{Metode og materiale}

Datamaterialet i denne studien stammer fra TALIS-undersøkelsen fra 2018. TALIS er et akronym for «Teaching and Learning International Survey», som er en internasjonal undersøkelse av læreres og skolelederes yrkeshverdag og arbeidsbetingelser (se bokas kapittel 1). Denne undersøkelsen gjennomføres av Organisation for Economic Cooperation and Development (OECD). Datasettet som er anvendt, framkom på følgende måte: Spørreskjema ble sendt til skoleledere på ungdomstrinnet i norske skoler. Utvalgsmetoden er en to-trinns prosess, som er omtalt andre steder i denne boka. Som nevnt i TALIS-undersøkelsens tekniske rapport, er svarene til hver skoleleder i utvalgsdesignet vektet $\mathrm{i}$ analysene for å bli gyldige for hele populasjonen av norske skoleledere. Spørreskjemaet ble besvart av 162 norske skoleledere.

Som teksten ovenfor viser, har vi utviklet teoretisk begrunnede antakelser mellom flere begreper. Flere indikatorer ble anvendt for å utforske ett og samme underliggende begrep. Gjennom kjøringer av faktoranalyser og andre statistiske analyser, ble indikatorene valgt ut på grunnlag av deres psykometriske egenskaper.

I analysene brukte vi både begreper som inngår i den internasjonale delen av studien og begreper som inngår i den norske delen av studien. Deskriptiv statistikk for indikatorene er gitt i tabell 1. Begrepet «undervisningsstøtte» er konstruert med tre indikatorer, mens begrepet «stress» er konstruert med fire indikatorer. Indikatorene til begrepet «innovasjonsstøtte» er hentet fra Siegel og Kaemmerer (1978), men de er modifisert. Vi gjennomførte reliabilitetsanalyse, og kom fram til at alle begrepene i strukturmodellen anses å være tilfredsstillende eller nær opp til det som anses som tilfredsstillende reliabilitet (Crocker \& Algina, 1986). Indikatorene oppgis i tabell 1. Den foreslåtte faktorstrukturen med fire faktorer har blitt bekreftet i en eksplorerende faktoranalyse.

$\mathrm{Vi}$ anvendte strukturell likningsmodellering for å analysere relasjonene mellom variablene som inngår i modellen som angis i figur 1 (Kline, 2005). MPlus-programmet ble benyttet i analysen. Strukturell likningsmodellering kombinerer egenskaper fra en psykometrisk forskningstradisjon (med dens anvendelse av flere indikatorer for et underliggende begrep) og en økonometrisk forskningstradisjon (med dens estimering 
av gjensidige styrkeforhold mellom ulike relasjoner som inngår i strukturmodellen, figur 2). «Maximum likelihood»-tilnærmingen ble brukt for å estimere parametrene i modellen. Vi anvendte visse standardkriterier (p>.05; RMSEA<.06; SRMR<.08; CFI>.90; and TLI>.90) for å vurdere modellenes tilpasningsegenskaper (jf. Bentler \& Yuan, 1999). De aktuelle verdiene som er funnet i analysen, er nært opp til det som er tilfredsstillende for det formål denne studien har.

\section{Resultater og drøfting}

Formålet med studien var å gjennomføre en analyse som bidrar til at vi bedre kan forstå hvordan ulike forhold ved skolen er relatert til skolelederens jobbtilfredshet. For det første undersøkte vi alle indikatorer når det gjelder fordelingsegenskaper (se vedlegg). Indikatorene har tilfredsstillende verdier for skjevhet og kurtose (Kline, 2015). Da vi testet modellen fra figur 1, indikerte tilpasningsindeksene en strukturmodell med følgende egenskaper: $\chi^{2}(84)=137 ; \mathrm{P}>.000 ; \mathrm{RMSEA}=.065 ; \mathrm{SRMR}=.072$; $\mathrm{CFI}=.892 ; \mathrm{TLI}=.865$. Figur 2 viser strukturmodellen.

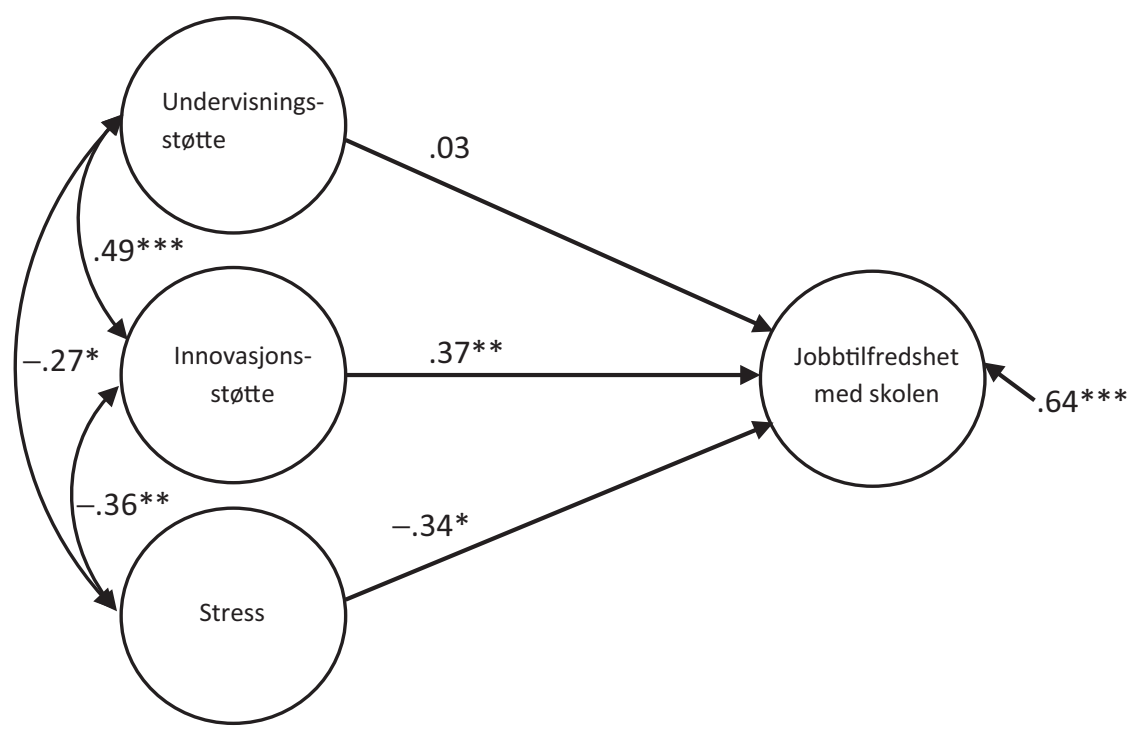

Figur 2 Empiriske relasjoner mellom rektorers jobbtilfredshet og undervisningsstøtte, innovasjonsstøtte og stress. 
Hovedkonklusjonen i denne artikkelen er at innovasjonsstøtte og stress er relatert til rektorers jobbtilfredshet, mens undervisningsstøtte ikke er relatert til jobbtilfredshet med skolen. Videre finner vi at rektorers opplevelse av stress er negativt relatert til innovasjonsstøtte og undervisningsstøtte, så vel som jobbtilfredshet. En mulig tolkning er at stress kan oppfattes som en hemmende faktor i rektorers arbeid, ettersom jobbtilfredshet må antas å være viktig for skolens langsiktige arbeid med utvikling og forbedring. Den form for stress som denne artikkelen fokuserer på, er det å ha for mye arbeid med å følge opp lærernes faglige og profesjonelle utvikling, å ha for mye administrativt arbeid å gjøre, samt å ha ekstraoppgaver på grunn av fravær i personalet. Dette er stress som først og fremst knytter seg til forholdet mellom rektorers arbeidskapasitet og deres ambisjoner om å gjøre en god jobb som rektor. Dette funnet er i overensstemmelse med Bjørseth og Kindt (2019), som finner at når arbeidsbelastningen er for høy, går dette ut over bidraget til skoleutvikling (altså innovasjonsstøtte). Videre er det også en negativ relasjon mellom stress og undervisningsstøtte. Dersom disse empiriske assosiasjonene avspeiler kausale prosesser, vil en implikasjon være at det er en fordel dersom det bygges opp større ledelseskapasitet på skolene. Dersom ledelseskapasiteten bygges opp, kan rektorer delegere flere administrative oppgaver. Dermed kan det frigjøres mer kapasitet til forbedringsarbeid på skolene: undervisningsstøtte og innovasjonsstøtte. Dette spørsmålet handler også indirekte om finansiering av ledelseskapasitet på skoler i forhold til arbeidsoppgaver. Dette er i så fall et spørsmål om ressursallokering. Det vi ikke vet, er om rektorers arbeidskapasitet for å håndtere utvikling og innovasjon kan skjermes uten at dette går ut over andre forefallende oppgaver som rektorer normalt har (eksempelvis å følge opp konsekvenser av rettsliggjøringen innad i skoler, følge opp foreldrekontakt o.l.).

Dersom situasjonslogikken for rektors arbeid legger føringer for at rektorer må prioritere foreldrekontakt, skoleeierkontakt, oppfølging av elevrettigheter definert av opplæringsloven o.l., vil dette kunne tenkes å gå på bekostning av arbeidet med å følge opp undervisningsstøtte og innovasjonsstøtte: «Extra allt kan utlovas [som ønsketenkning i samfunnet, fra lovgiverne etc.], men inte leveras [av rektorene]» (Alvesson, 2019, s. 246). Dersom dette er riktig, vil ønsketenkningen kunne slå tilbake på 
skolens viktige, kontinuerlige forbedringsbestrebelser. Dette er en interessant ide å forfølge i framtidig forskning. Flere empiriske faktorer må i så fall innbefattes $i$ analysen for at vi skal forstå fenomenet rektorers overbelastningsproblem og konsekvensene av overbelastningsproblemet bedre. Også flere datakilder enn rektorers subjektive opplevelse av sin arbeidssituasjon bør inngå i en analyse av skolens muligheter og begrensinger i arbeidet med å forbedre skolens virksomhet gjennom undervisningsstøtte, innovasjonsstøtte og andre faktorer som er viktige i skolens forbedringsarbeid (Bryk et al., 2015; Lewis, 2015).

Vi må erkjenne at denne studien har en rekke begrensninger av konseptuell art så vel som empirisk art. Disse begrensningene gir forhåpentligvis ideer som kan forfølges i framtidig forskning.

I denne studien er skoleeksterne forhold i liten grad berørt ut over konsekvenser for rektorers arbeidsbelastning i form av opplevd stress. Danielsen og Kleiven (2019) fant i sin gjennomgang av forskning at målstyring i skolesektoren gir uttrykk for en høy grad av opplevd mistillit, samt at rektorene opplever at målstyring hindrer dem i å være autentiske og i å styrke og utvikle sine ansatte. For å kunne ha bedre empiriske indikasjoner på dette, vil framtidig forskning kunne legge vekt på enda bredere sett av variabler som undersøker de ytre faktorenes betydning for rektorers jobbtilfredshet. En interessant mulighet å basere seg på, er Hackmans og Oldhams (1980) skille mellom interne og eksterne kilder til jobbtilfredshet. En klar implikasjon for videre forskning kan være å utforske hvordan slike ytre faktorer påvirker rektorers jobbtilfredshet.

\section{Referanser}

Alvesson, M. (2019). Extra allt. Fri Tanke.

Bentler, P. M. \& Yuan, K. H. (1999). Structural equation modeling with small samples: Test statistics. Multivariate behavioral research, 34(2), 181-197. https://doi. org/10.1207/S15327906Mb340203

Bergsli, A. T. (2020, 5. februar). Gryende lederkrise i skolen. Forskning.no. https:// forskning.no/fafo-ledelse-og-organisasjon-partner/gryende-lederkrise-iskolen/1632185

Bjørnset, M. \& Kindt, M. T. (2019). Fra gallionsfigur til overarbeidet altmuligmann? Rekruttering av skoleledere i norsk skole (Fafo-rapport 2019:37). https://www.fafo. 
no/zoo-publikasjoner/fafo-rapporter/item/fra-gallionsfigur-til-overarbeidetaltmuligmann

Blase, J. \& Blase, J. (2000). Effective instructional leadership. Journal of Educational Administration. 38(2), 130-141. https://doi.org/10.1108/09578230010320082

Bryk, A. S., Gomez, L. M., Grunow, A. \& LeMahieu, P. G. (2015). Learning to improve: How America's schools can get better at getting better. Harvard Education Publishing. Brayfield, A. H. \& Rothe, H. F. (1951). An index of job satisfaction. Journal of Applied Psychology, 35(5), 307-311. https://doi.org/10.1037/hoo55617

Chaplain, R. P. (2001). Stress and job satisfaction among primary headteachers: A question of balance? Educational Management \& Administration, 29(2), 197-215. https://doi.org/10.1177/0263211X010292005

Crocker, L. \& Algina, J. (1986). Introduction to classical and modern test theory. Holt, Rinehart and Winston.

Danielsen, J. \& Kleiven, J. (2019). Tjenende ledelse i et målstyringssystem: En kvalitativ eksplorerende studie av rektor som tjenende leder [Master's thesis, Norges Handelshøyskole]. Brage. http://hdl.handle.net/11250/2623481

Dee, J. R., Henkin, A. B. \& Pell, S. W. (2002). Support for innovation in site-basedmanaged schools: Developing a climate for change. Educational Research Quarterly, 24(4), 36-49. https://search.proquest.com/docview/216183766?pq-origs ite $=$ gscholar \&fromopenview $=$ true

Demir, S. (2018). The relationship between psychological capital and stress, anxiety, burnout, job satisfaction, and job involvement. Eurasian Journal of Educational Research, (75), 137-153. https://files.eric.ed.gov/fulltext/EJ1181447.pdf

Elstad, E. (2009). Styring, ansvarliggjøring og ansvarsfraskrivelse. I E. L. Dale (Red.), Loreplan $i$ et forskningsperspektiv (s. 116-153). Universitetsforlaget.

Engels, N., Hotton, G., Devos, G., Bouckenooghe, D. \& Aelterman, A. (2008). Principals in schools with a positive school culture. Educational Studies, 34(3), 159-174. https://doi.org/10.1080/03055690701811263h

Hackman, J. R. \& Oldham, G. R. (1980). Work redesign. Addison-Wesley.

Hallinger, P. (2010). Developing instructional leadership. I B. Davies \& M. Brundrett (Red.), Developing successful leadership (s. 61-76). Springer.

Hoppock, R. (1935). Job satisfaction. Harper.

Houser, J. D. (1927). What the Employer Thinks. Cambridge, MA: Harvard University Press.

Kline, R. B. (2015). Principles and practice of structural equation modeling. Guilford publications.

Lee, C. S., Chen, Y. C., Tsui, P. L. \& Yu, T. H. (2014). Examining the relations between open innovation climate and job satisfaction with a PLS path model. Quality \& Quantity: International Journal of Methodology, 48(3), 1705-1722. https://doi. org/10.1007/s11135-013-9869-6 
Lejonberg, E., Elstad, E. \& Christophersen, K. A. (2018). Teaching evaluation: Antecedents of teachers' perceived usefulness of follow-up sessions and perceived stress related to the evaluation process. Teachers and Teaching, 24(3), 281-296. https://doi.org/10.1080/13540602.2017.1399873

Lewis, C. (2015). What is improvement science? Do we need it in education? Educational Researcher, 44(1), 54-61. https://doi.org/10.3102/o013189X15570388

Liu, Y., Bellibaş, M. Ş. \& Gümüş, S. (2020). The effect of instructional leadership and distributed leadership on teacher self-efficacy and job satisfaction: Mediating roles of supportive school culture and teacher collaboration. Educational Management Administration \& Leadership. https://doi. org/10.1177/1741143220910438

Locke, E. A. (1969). What is job satisfaction? Organizational Behavior and Human Performance, 4(4), 309-336. https://doi.org/10.1016/o030-5073(69)90013-0

Moolenaar, N. M., Daly, A. J. \& Sleegers, P. J. (2010). Occupying the principal position: Examining relationships between transformational leadership, social network position, and schools' innovative climate. Educational Administration Quarterly, 46(5), 623-67o. https://doi.org/10.1177/oo13161X10378689

Moolenaar, N. M., Daly, A. J. \& Sleegers, P. J. (2011). Ties with potential: Social network structure and innovative climate in Dutch schools. Teachers College Record, 113(9), 1983-2017. https://hdl.handle.net/11245/1.375173

Moolenaar, N. M., Daly, A. J., Cornelissen, F., Liou, Y. H., Caillier, S., Riordan, R., Wilson, K. \& Cohen, N. A. (2014). Linked to innovation: Shaping an innovative climate through network intentionality and educators' social network position. Journal of Educational Change, 15(2), 99-123. https://doi.org/10.1007/s10833-0149230-4

Møller, J. (2019). Nye leder- og lærerroller i skolen - konsekvenser for rektorrollen. I K. Helstad \& S. Mausethagen (Red.), Nye loerer- og lederroller i skolen (s. 185-204). Universitetsforlaget.

Robinson, V. M., Lloyd, C. A. \& Rowe, K. J. (2008). The impact of leadership on student outcomes: An analysis of the differential effects of leadership types. Educational Administration Quarterly, 44(5), 635-674. https://doi. org/10.1177/0013161Xo8321509

Siegel, S. M. \& Kaemmerer, W. F. (1978). Measuring the perceived support for innovation in organizations. Journal of Applied Psychology, 63(5), 553-562. https:// doi.org/10.1037/0021-9010.63.5.553

Silva, T. M. E. (2011). Rektor i en resultatstyrt skole: En analyse av tre Oslorektorers fortellinger om sin hverdag $i$ en ansvarliggjøringskultur i lys av teori om borekraftig ledelse. Universitetet i Oslo. 
Vedvik, K. O. (2020, 26. oktober). Stort gjennomtrekk av rektorer i Trondheim. Utdanningsnytt. https://www.utdanningsnytt.no/kommune-rektor/stortgjennomtrekk-av-rektorer-i-trondheim $/ 259163$

Waldron, N. L. \& McLeskey, J. (2010). Establishing a collaborative school culture through comprehensive school reform. Journal of Educational and Psychological Consultation, 20(1), 58-74. https://doi.org/10.1080/10474410903535364

Aass, S. H. (2011). 120 dager med rektor [Matergradsoppgave, Norges tesknisknaturvitenskapelige universitet]. https://www.ntnu.no/documents/1021451972/ 1267715896/sverre-halvard-aass-2014.pdf/a5b7b39f-059c-4581-a8eo-91edcbf714a9 


\section{Vedlegg}

Tabell 1 Beskrivende statistikk, og informasjon om reliabilitet (Cronbachs $\alpha$ ).

\section{Faktor}

Ind. nr. Gj.sn. SA Skjevhet Kurtose $\alpha$

Undervisningsstøtte

Jeg støttet opp om samarbeid mellom lærerne med tanke på å utvikle ny undervisningspraksis

Jeg forsikret meg om at lærerne tar ansvar for å forbedre sin undervisning

$\begin{array}{lllll}2 & 2.51 & 0.68 & -0.09 & -0.21\end{array}$

Jeg forsikret meg om at lærerne føler ansvar for elevenes læringsresultater

$\begin{array}{lllll}3 & 2.84 & 0.64 & -0.68 & 1.18\end{array}$

\section{Innovasjonsstøtte}

Skolen ser raskt behovet for å gjøre ting på en annen måte

Skolen er rask til å reagere når det er nødvendig å foreta endringer

Nye ideer blir lett akseptert på denne skolen

Ved denne skolen er det lett å få hjelp til å utvikle nye ideer

$\begin{array}{llllll}2 & 2.97 & 0.44 & -0.17 & 2.16 \\ 3 & 2.77 & 0.61 & -0.29 & 0.27 \\ 4 & 2.87 & 0.52 & -0.33 & 0.89\end{array}$

\section{Stress}

$\AA$ ha for mye arbeid med å følge opp læreres faglige og profesjonelle utvikling

Å være ansvarlig for elevenes prestasjoner

$\AA$ opprettholde disiplinen i skolen

A håndtere foreldrenes eller foresattes bekymringer

\section{Jobbtilfredshet knyttet til skolen}

Jeg liker å arbeide ved denne skolen

Jeg vil gjerne anbefale denne skolen som arbeidsplass

Jeg er tilfreds med måten jeg utfører arbeidet mitt på denne skolen

Når alt kommer til alt, er jeg fornøyd med jobben $\min$

$\begin{array}{llllll}1 & 2.04 & 0.79 & 0.47 & -0.11 & \\ 2 & 2.07 & 0.82 & 0.32 & -0.57 & \\ 3 & 1.79 & 0.78 & 0.80 & 0.27 & \\ 4 & 2.21 & 0.80 & 0.19 & -0.48 & \\ & & & & & .65 \\ 1 & 3.63 & 0.54 & -1.37 & 2.40 & \\ 2 & 3.62 & 0.59 & -1.81 & 4.52 & \\ 3 & 3.02 & 0.41 & 0.18 & 3.00 & \\ 4 & 3.31 & 0.53 & -0.24 & .034 & \end{array}$

Note: Gj.sn. = Gjennomsnitt; $S A=$ Standardavvik 



\title{
Hva fremmer et innovativt miljø i skolen, og hvilken betydning har det for læreres undervisning?
}

\author{
Trude Nilsen \\ Institutt for lærerutdanning og skoleforskning, Universitetet i Oslo \\ Ronny Scherer \& Sigrid Blömeke \\ Centre for Educational Measurement (CEMO), Universitetet i Oslo
}

\begin{abstract}
What encourages an innovative environment in schools and what does that imply for teaching?

An innovative environment is important for a school's ability to adapt to societal changes and for students' ability to cope with future society. It is therefore crucial to find out what promotes an innovative environment in a school and what consequences an innovative environment has for teaching and learning. Certain aspects of teaching are especially important for students to learn how to cope with a society where, for instance, critical thinking and problem solving are required and where diversity is increasing. Such teaching practices include cognitive activation and inclusive practices.

Using TALIS 2018, we employ two-level (teachers and schools) structural equation modelling to examine both direct and indirect effects of distributed leadership on teaching practices via an innovative environment. Results show that distributed leadership has a medium strong relationship to an innovative environment and that an innovative environment has a medium strong relationship to teaching practices. An innovative environment mediates the effect of distributed leadership on teaching practices.

Overall, our study has implications for policy and practice as it finds that school leaders who employ distributed leadership can help promote an innovative environment and that an innovative environment in turn may encourage the type of teaching students need to acquire skills that are important in the 21 st century.
\end{abstract}

Keywords: innovative environment, distributed leadership, teaching practices

Sitering av denne artikkelen: Nilsen, T., Scherer, R. \& Blömeke, S. (2021). Hva fremmer et innovativt miljø i skolen, og hvilken betydning har det for læreres undervisning? I J. K. Björnsson (Red.), Hva kan vi loere av TALIS 2018? Gode relasjoner som grunnlag for loering (Kap. 3, s. 35-55). Cappelen Damm Akademisk. https://doi.org/10.23865/noasp.123.ch3

Lisens: CC BY-NC-ND 4.0. 


\section{Introduksjon}

Innovasjon (det vil si, generering og implementering av nye ideer) i skolen har blitt utnevnt som et kriterium for skolens tilpasningsevne til samfunnsendringer og som viktig for en bærekraftig utvikling (Hallgarten et al., 2015; Hargreaves, 2003; Janssen, 2000; Meld. St. 30 (2019-2020); OECD, 2014). Innovasjon i skolen ansees også for å være viktig for at elever skal klare seg i morgendagens samfunn: klare å holde tritt med den digitale utviklingen, klare seg i fremtidens arbeidsmarked, og tilpasse seg et heterogent, flerkulturelt samfunn (Voogt \& Roblin, 2012). Elever trenger kompetanser man regner med blir ekstra viktige i det 21. århundre, populært kalt «21st century skills», som blant annet inkluderer kritisk tenkning, kreativitet, evne til problemløsning, samarbeid, digital kompetanse og fleksibilitet (Dede, 2010).

Forskning tyder på at et innovativt miljø, altså et miljø hvor individer er åpne for endringer og nye ideer og villige til selv å implementere disse, er et fundament og en forutsetning for slike kompetanser (Voogt \& Roblin, 2012). Et innovativt miljø blant skoleledere og lærere kan også drive utviklingen av selve utdanningen videre, og bidra til at skoleledere og lærere skal kunne håndtere et heterogent skolemiljø med stort mangfold $i$ et samfunn i rask endring (OECD, 2013, 2014).

Det er dog lite forskning på hvor innovativt miljøet innenfor skolen er, både internasjonalt og nasjonalt her i Norge (Blömeke et al., under utgivelse), og det meste av forskningen stammer fra organisasjonspsykologi innen arbeidsmarkedet (Anderson \& West, 1998). Her har forskere funnet at organisasjoner som har et innovativt miljø har en positiv påvirkning på ansattes oppførsel, slik at ansatte blir mer innovative (Patterson et al., 2005). Nylig har denne forskningen blitt adoptert til også å gjelde skoler, i første omgang med hensyn til lærernes teknologibruk, og man antar at på skoler som er åpne for nye ideer og endringer, vil lærere reagere positivt til nye typer undervisning (OECD, 2014, 2019).

Lærerne og deres undervisning er en av de viktigste faktorene for elevers læringsutbytte (Hattie, 2009; Nilsen \& Gustafsson, 2016; Praetorius et al., 2018). For at elevene skal få den kompetansen de 
behøver for å klare seg i fremtiden, tyder forskning på at det er formålstjenlig at lærerne yter nye typer undervisning som er nødvendig for at elevene kan erverve slik kompetanse. Det ser blant annet ut som at det er viktig å gi inkluderende undervisning hvor elever blir forberedt på å leve i et heterogent samfunn med stort mangfold (Dumont \& Istance, 2010). Forskning tyder videre på at det er viktig å gi kognitivt stimulerende undervisning hvor blant annet elever lærer om problemløsning og det å tenke kritisk (Klieme et al., 2009; Kunter et al., 2013; Praetorius et al., 2018). Slik undervisning kan bygge opp under elevers fremtidige evne til innovasjon, som er viktig i det 21. århundre (Thurlings et al., 2015).

Lærerne er også et viktig bindeledd mellom skoleledelsen og elevene. På samme måte som elever blir påvirket av lærerens undervisningskvalitet, kan vi gå ut fra at lærerne i sin tur blir påvirket av ledelsen på skolen (Møller \& Ottesen, 2011). Det hjelper nok ikke at skoleledelsen har en visjon om innovasjon hvis ikke ledelsen når frem til sine lærere. Forskning innen skoleledelse tyder på at dersom beslutninger blir distribuert slik at lærere, foreldre og elever får mulighet til aktivt å delta i beslutningsprosesser, så gagner det både lærere og elever (Harris, 2014). Derfor kan det ansees som formålstjenlig at skolen har en kultur med delt ansvar for skolespørsmål, og som er preget av gjensidig støtte og samarbeid (Hallinger \& Heck, 2010). Distribuert ledelse er også positivt korrelert med læreres undervisningskvalitet (Harris, 2014).

Kunnskap om hvorvidt distribuert ledelse skaper grobunn for et innovativt skolemiljø og for innovative lærere, og om et innovativt miljø i sin tur har sammenheng med nye typer undervisning som er stimulerende og inkluderende, kan bidra til å kaste lys over rollen innovasjon spiller i skolen. Hvilke faktorer fremmer et innovativt miljø, og hva kan et slikt miljø bidra til? Siden det finnes lite forskning på dette (Blömeke et al., under utgivelse; Thurlings et al., 2015), er vårt mål å bidra til å lukke dette gapet i forskningen om forhold i Norge ved å undersøke:

I hvilken grad har distribuert skoleledelse sammenheng med et innovativt skolemiljø i norsk skole, og hvordan har et slikt miljø i sin tur sammenheng med loereres undervisning (stimulerende og inkluderende undervisning)? 


\section{Teoretisk rammeverk \\ Distribuert ledelse}

Distribuert ledelse er et begrep fra organisasjonsteori innen feltet skoleledelse, og handler om at beslutningsprosesser ikke hviler ene og alene på skoleledere, men at også lærere, foreldre og elever er med på å ta beslutninger om skolen (Hallinger \& Heck, 2010; Harris, 2014).

Distribuert ledelse kan forståes på forskjellige måter. Hovedsakelig er det to tilnærminger innenfor begrepsteorien: 1) ledelse som praksis og 2) leder-pluss tilnærmingen (Gronn, 2002; Spillane, 2006, 2012). Ledelse som praksis handler om mer enn det å delegere ledelse. Det handler om å flytte oppmerksomheten fra individuelle handlinger til ledelse som praksis (Jensen, 2020; Møller \& Ottesen, 2011). Distribuert ledelse inkluderer interaksjoner mellom ledere og de som blir ledet, hvor kontekst og situasjon spiller en viktig rolle (Spillane, 2006). Leder-pluss dreier seg om å plusse på det den ene gjør av ledelseshandlinger med det en annen gjør. Her er ikke søkelyset lenger på ledelse som praksis, men rettes i stedet mot roller og funksjoner.

Generelt trekkes det frem tre viktige elementer ved distribuert ledelse: samarbeid om beslutninger, gi ansatte, foreldre og studenter muligheter til å være med i beslutningsprosesser og oppmuntre til delt ansvar for studenters læring og for å evaluere skolens faglige utvikling (Hallinger \& Heck, 2010). Distribuering av ledelse forutsetter samarbeid, demokratiske prosesser, aktiv deltagelse og en delingskultur (Ainley \& Carstens, 2018; Harris, 2008).

I tråd med forskningen beskrevet over, defineres distribuert ledelse i denne studien som læreres, elevers og foreldres muligheter til medbestemmelse i beslutninger som angår skolen, som kultur for delt ansvar og som gjensidig støtte og samarbeid mellom alle parter i skolen. Denne definisjonen er i tråd med den teoretiske tilnærmingen til ledelse som praksis, fordi medbestemmelse, delt ansvar og samarbeid reflekterer skolens praksis for distribuert ledelse.

I hvilken grad distribuert ledelse har betydning for å støtte opp et innovativt skolemiljø på skolen, finnes det lite forskning på. De få studiene som finnes tyder på at distribuert ledelse kan ha betydning for en 
suksessfull endring i skolen (Harris, 2008) og generelt for en effektiv og suksessfull ledelse. Dersom skoleledere har en visjon for innovasjon i skolen, må denne visjonen kunne forplante seg gjennom hele skolen for å iverksettes effektivt. Forskningsresultatene kan tyde på at distribuert ledelse er en effektiv måte å få til dette på (Hallinger \& Heck, 2010). Det kan derfor også tenkes at distribuert ledelse har en indirekte effekt på læreres undervisningskvalitet via et innovativt skolemiljø, slik at miljøet kan virke som en trigger på effekten av distribuert ledelse på læreres undervisningskvalitet.

\section{Et innovativt miljø}

Det å ha et innovativt miljø har blitt et populært begrep og benyttes mye i forskning om og utvikling i arbeidsmarkedet. Et slikt miljø blir definert som ansattes oppfatning av et arbeidsmiljø som er åpent for innovasjon og endring (Patterson et al., 2005). Men i senere tid har ønsket om å bygge opp et innovativt miljø også blitt knyttet til skoler, først til læreres teknologibruk (Van Braak, 2001) og senere også til andre temaer. Det ligger nå forventninger om at skolen skal være åpen for endringer og tilpasse seg endringer i samfunnet (OECD, 2014).

Som pekt på innledningsvis kan innovasjon defineres som generering og implementering av nye ideer (Janssen, 200o). Et innovativt miljø i organisasjoner kjennetegnes ved at de ansatte har en delt oppfatning om at arbeidsmiljøet er åpnet for innovasjon og forandring. Et slikt miljø anses som essensielt for at en organisasjon klarer å implementere nye typer adferd (se f.eks. Anderson \& West, 1998; Baltes, 2001).

Selv om «innovativt miljø» er et veletablert begrep, så varierer definisjonene på tvers av studier innen forskning, og det er ofte uklart hva som rent konkret menes med det. Litteraturen viser at det er tre måter å forstå innovasjon på: 1) som individuelle holdninger (Hurt et al., 1977), 2) som en psykologisk karakteristikk av miljøet målt og analysert på individnivå (Anderson \& West, 1998), og 3) som en organisasjonskarakteristikk av miljøet, målt på individnivå, men aggregert og analysert på organisasjonsnivå. Det finnes langt flere studier hvor innovasjon er målt som individuelle holdninger (for eksempel ved utsagn som: «jeg er åpen for 
nye ideer»), enn som organisasjonskarakteristikker ved miljø. Fra et tidlig stadium i forskningen (f.eks. Hurt et al., 1977) og til i dag, har de fleste empiriske studier på innovasjon innen utdanning lagt vekt på individuelle læreres holdning. Likevel peker tidligere forskning på at det samtidig er et behov for å ta miljø i betraktning (Thurlings et al., 2015).

I denne studien er et innovativt skolemiljø derfor operasjonalisert som en karakteristikk av miljø, og ikke som individuelle holdninger. Vi følger dermed McGeowns (1979) teori, som sier at den psykologiske karakteristikken og organisasjonskarakteristikken gjensidig påvirker hverandre. Med andre ord, det innovative miljø på en skole vil påvirke de individuelle lærere på skolen, og de individuelle lærere vil påvirke miljøet på skolen. Her måles derfor et innovativt skolemiljø gjennom de individuelle læreres oppfatning av hvorvidt miljøet på skolen deres er innovativt og åpent for endring, og gjennom de delte oppfatningene til alle lærerne på skolens miljø. Vi undersøker dermed innovasjon både som en psykologisk karakteristikk og som en organisasjonskarakteristikk av miljø.

Innen organisasjonsteori finner man at dersom ansatte har en delt oppfatning om at organisasjonen er innovativ, så vil de ansatte også agere på en innovativ måte og implementere innovative ideer (Patterson et al., 2005). Man antar at det samme gjelder på skoler, og at lærere som jobber på innovative skoler, vil yte mer innovativ undervisning (Blömeke et al., under utgivelse; Thurlings et al., 2015). En systematisk gjennomgang av 37 kvalitative og kvantitative studier fant en positiv effekt av innovative holdninger ved lærere på innovativ undervisning i sammenheng med teknologibruk (Thurlings et al., 2015). Imidlertid vet vi lite om dette i Norge og lite når det gjelder andre utfallsmål.

\section{Læreres undervisningskvalitet}

Læreres undervisningskvalitet er et bredt begrep som inneholder mange aspekter (Nilsen \& Gustafsson, 2016; Praetorius et al., 2018). Undervisningskvalitet defineres som de aspektene ved lærerens undervisning som forskning har vist har en positiv effekt på elevers læringsutbytte (Baumert et al., 2010; Klieme et al., 2009). 
Det finnes flere rammeverk for undervisningskvalitet, men det som er mest anerkjent i Europa (Klieme et al., 2009; Praetorius et al., 2018) inneholder 3 hovedaspekter: 1) klasseledelse, 2) kognitivt stimulerende undervisning og 3) støttende undervisning.

I denne studien fokuserer vi på kognitivt stimulerende undervisning og støttende undervisning, da innovasjon antas å spille en mindre viktig rolle for klasseledelse.

Kognitivt stimulerende undervisning handler om å utfordre og stimulere elevene kognitivt, til å strekke seg litt lenger. Slik undervisning går ut på å lære elever problemløsning, å tenke kritisk, å samarbeide for sammen å finne løsninger på problemer som ikke har en opplagt løsning og å overføre kunnskap til nye kontekster og resonere (Baumert et al., 2010; Schlesinger et al., 2018). Slike kompetanser er viktige for at elevene skal klare seg i det 21. århundre og for selv å kunne bli innovative (Dede, 2010). Kognitivt stimulerende undervisning har vist seg å ha en positiv effekt på elevers læringsutbytte (Kunter et al., 2013).

Dimensjonen støttende undervisning handler om at læreren gir den nødvendige støtten enkeltelever trenger både faglig og emosjonelt (Klieme et al., 2009; Pianta et al., 2008). Inkluderende undervisning er her et viktig element. Det at lærere takler et heterogent klassemiljø med kulturelt mangfold og underviser elever i hvordan de bør håndtere diskriminering på bakgrunn av etnisitet og kultur, er viktig. Videre er det essensielt at lærere forsøker å utvide elevers horisont ved å innlemme globale, og ikke bare nasjonale, temaer i undervisningen. Undervisning som støtter elever inkluderer støtte både til minoritetselever, men også til majoriteten, slik at begge disse elevgruppene er rustet til å møte et heterogent samfunn. Støttende undervisning har vist seg å ha en positiv effekt på elevers læringsutbytte (Baumert et al., 2010; Nilsen \& Gustafsson, 2016; Praetorius et al., 2018).

Selv om det er lite forskning på i hvilken grad et innovativt skolemiljø påvirker hvor kognitivt stimulerende og inkluderende undervisning lærere yter, kan tidligere forskning tyde på at lærere som er åpne for nye ideer og som jobber på skoler med et åpent og innovativt miljø i større grad vil gi elever slik type undervisning (Blömeke et al., under utgivelse; Thurlings et al., 2015). Men om dette også gjelder Norge, er et åpent spørsmål. 


\section{Forskningsspørsmål}

Gjennomgangen av tidligere forskning på innovasjon, skoleledelse og undervisningskvalitet over viser at det finnes forskning på innovasjon innen arbeidsmarkedet og organisasjonspsykologi, men at det er lite forskning på innovasjon i skolen. På samme måte er det forskning innen distribuert ledelse og undervisningskvalitet, men få har satt disse i sammenheng med innovasjon. Videre har (som tidligere nevnt) forskning vist at det er viktig å skille mellom innovasjon som en praksis, og innovasjon som en karakteristikk av miljøet på organisasjonsnivå.

For å imøtekomme behovet for forskning på hvilken rolle et innovativt miljø har i skolen, hvordan ledelsen kan legge til rette for et innovativt miljø og hvilke konsekvenser et slikt miljø har for læreres undervisning, både på et individuelt nivå (lærere) og på et organisasjonsnivå (skoler), stiller vi følgende forskningsspørsmål:

1) Hva er sammenhengen mellom distribuert ledelse og et innovativt skolemiljø, og hvordan påvirker et slikt miljø læreres undervisningskvalitet (kognitivt stimulerende undervisning og inkluderende undervisning) på skolenivå?

2) Hva er sammenhengen mellom enkeltlæreres oppfatning av distribuert ledelse og deres oppfatning av hvor innovativt miljøet på skolen er, og hvordan påvirker enkeltlæreres oppfatning av miljøet deres undervisningskvalitet (kognitivt stimulerende undervisning og inkluderende undervisning) på loerernivå?

3) I hvilken grad har distribuert ledelse en indirekte effekt på læreres undervisningskvalitet via miljøet på loerer-og skolenivå?

\section{Metode}

\section{Om TALIS og utvalget}

Teaching and Learning International Survey (TALIS) er en internasjonal OECD-undersøkelse av læreres og skolelederes yrkeshverdag (OECD, 2019). Lærere svarer på spørsmål om for eksempel deres undervisning, holdninger, yrkesbakgrunn og utdanning, og skoleledere svarer på spørsmål om for eksempel skoleledelse og skolemiljø. I 2018 var 48 land med. 
Undersøkelsen ble gjennomført i 2008, 2013 og 2018. Vårt utvalg inkluderer norske ungdomsskoler skoler (185) og deres lærere (3997) som deltok i 2018. Gjennomsnittlig antall lærere per skole var 21,6.

Undersøkelsen har et såkalt hierarkisk design fordi utvalget består av flere lærere per skole. Lærere på samme skole vil som regel ligne mer på hverandre enn lærere på forskjellige skoler. Når man analyserer et slikt hierarkisk utvalg, må man ta hensyn til dette ved for eksempel flernivåanalyse.

\section{Hvordan måles et innovativt miljø, distribuert ledelse og undervisningskvalitet?}

Vi benyttet spørreskjema til lærere som er basert på det teoretiske rammeverket til TALIS 2018 (Ainley \& Carstens, 2018). For å måle et begrep som for eksempel distribuert ledelse, lager man et såkalt konstrukt. Et konstrukt er en samlevariabel og består av en mengde spørsmål om det samme begrepet.

For å måle konstruktet distribuert ledelse i TALIS fikk lærerne et spørsmål om hvor enige de var i følgende påstander om skolen sin:

- Denne skolen gir personalet muligheter for medbestemmelse i beslutninger som angår skolen.

- Denne skolen gir foreldrene muligheter for medbestemmelse i beslutninger som angår skolen.

- Denne skolen gir elevene mulighet til medbestemmelse i beslutninger som angår skolen.

- Ved denne skolen er det kultur for delt ansvar i saker som angår skolen.

- Ved denne skolen er det kultur for å støtte hverandre og samarbeide

Lærerne krysset av for følgende alternativer: Svært uenig; Uenig; Enig; Svært enig.

Til sammen utgjør spørsmålet med de fem påstandene konstruktet distribuert ledelse.

For å måle et innovativt miljø, ble lærerne bedt om å tenke på lærerne ved sin skole og svare på hvor enige de var i følgende utsagn: Hvor enig eller uenig er du i følgende påstander? 
- De fleste loerere ved denne skolen arbeider for å utvikle nye undervisningsmetoder.

- De fleste lorerne ved denne skolen er åpne for forandringer.

- De fleste loererne ved denne skolen er løsningsorienterte.

- De fleste loererne ved denne skolen gir hverandre praktisk støtte i arbeidet med nye undervisningsmetoder.

Også her var svaralternativene: Svært uenig; Uenig; Enig; Svært enig.

For å måle kognitivt stimulerende undervisning ble lærerne bedt om å tenke på undervisningen sin i den aktuelle klassen og svare på hvor ofte de gjør følgende:

- Jeg presenterer oppgaver hvor det ikke er en opplagt løsning.

- Jeg gir oppgaver som krever at elevene tenker kritisk.

- Jeg lar elevene arbeide i mindre grupper for å finne felles løsninger på problemer eller oppgaver.

- Jeg oppfordrer elevene til å velge egne måter å løse komplekse oppgaver på.

Svaralternativene var: Aldri eller nesten aldri; Av og til; Ofte; Alltid.

For å måle inkluderende undervisning ble lærerne spurt om følgende praksiser ble implementert:

- Organisering av flerkulturelle arrangementer (f.eks. flerkulturell dag).

- Elevene blir undervist $i$ hvordan de bør håndtere diskriminering på bakgrunn av etnisitet og kultur.

- Bruk av undervisnings- og loeringspraksiser som integrerer globale temaer $i$ undervisningen

Svaralternativene var ja eller nei.

\section{Metode}

I denne studien benyttet vi såkalte strukturelle ligningsmodeller (SEM), som er en type regresjonsmodeller. Vi benyttet programvaren Mplus 8 
(Muthén \& Muthén, 1998-2017). Beskrivelsene av modelleringen er her forenklet for å øke lesbarheten.

Ved å bruke SEM, kan man gjøre analysene på både lærernivå og skolenivå samtidig. På skolenivå ble alle konstrukter (her målt som såkalt «latente variabler») aggregert fra lærernivå. I grove trekk vil det si at vi regner ut et slags gjennomsnitt av alle svarene til lærerne per skole. På den måten kan man undersøke forskjeller mellom skoler når det gjelder for eksempel læreres undervisningskvalitet.

På skolenivå undersøkte vi om distribuert ledelse har en sammenheng med et innovativt skolemiljø, og om det innovative skolemiljø har en sammenheng med læreres undervisning.

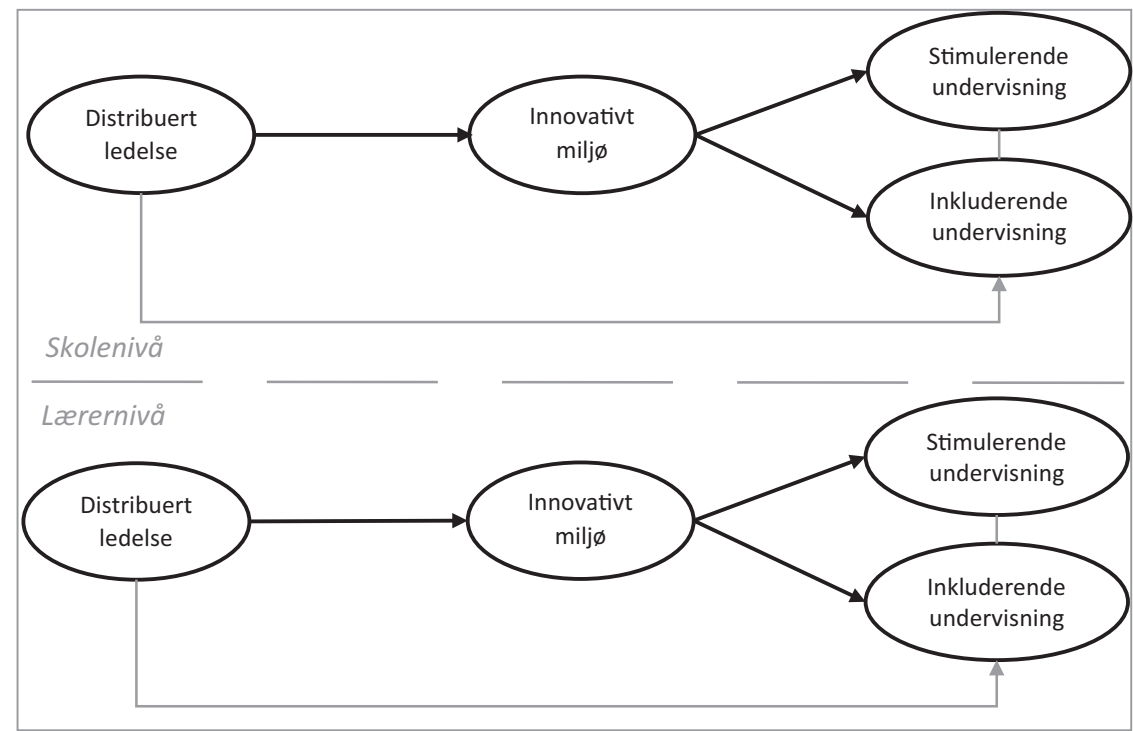

Figur 1 Figuren viser effekten av distribuert ledelse på et innovativt miljø, og effekten av et innovativt miljø på læreres undervisning (kognitivt stimulerende og inkluderende undervisning) på skole- og lærer-nivå.

Vi undersøkte de samme relasjonene på lærernivå, men på dette nivået har konstruktene en annen betydning. Her måles ikke et innovativt skolemiljø slik som på skolenivå, men læreres oppfatning av et innovativt skolemiljø. På lærernivå måles også læres oppfatning av distribuert ledelse.

Vi undersøkte også om distribuert ledelse har en indirekte effekt på læreres undervisning via et innovativt miljø på både skole- og lærernivå. 
Modellen er vist i figur 1, og den blå pilen viser den direkte effekten fra distribuert ledelse til læreres undervisning, mens den indirekte effekten går via et innovativt miljø. Mplus angir størrelsen på denne indirekte effekten og hvorvidt den er signifikant eller ei.

SEM gjør det også mulig å sjekke reliabiliteten og validiteten til konstruktene ved å regne ut hvor bra modellen passer dataene, og hvor bra de forskjellige spørsmålene i et konstrukt måler det underliggende begrepet (Hox et al., 2017). Dersom for eksempel et av spørsmålene til distribuert ledelse handlet om noe helt annet, så vil reliabilitetsmålene vise dette.

\section{Hvilke slutninger kan man dra basert på disse dataene?}

Metodene som er brukt her gir de mest korrekte, robuste og reliable resultatene (Hox et al., 2017). Men uansett er dette tverrsnittsdata, noe som betyr at undersøkelsen er målt på ett tidspunkt. TALIS har ikke et longitudinelt design, hvilket betyr at man ikke følger de samme lærere og skoleledere over tid. Det betyr at man ikke kan dra kausale slutninger, man kan altså ikke si at en hendelse (eller et fenomen) fører til en annen (eller et annet) (Gustafsson, 2013). Man kan kun undersøke om de to hendelsene (eller fenomenene) relatert. Dersom en variabel har en positiv sammenheng med en annen, betyr det at når den ene øker, så øker den andre. Det betyr ikke at dersom den ene øker, så medfører det at den andre øker. Strengt tatt betyr det at man ikke kan snakke om effekten av en variabel på en annen, men kun om sammenhengen mellom dem. Imidlertid kommer vi til å benytte ordet effekt av en variabel på en annen, for å gjøre det enklere for leseren å forstå resultater av disse komplekse analysene.

\section{Resultater}

Resultatene av analysene viste at modellen hadde bra anpasning til dataene. ${ }^{1}$ Videre var konstruktene reliable og valide. ${ }^{2}$

1 Målene på tilpasningen av modellen til dataene var: $\mathrm{RMSEA}=0,025, \mathrm{CFI}=0,955$ og TLI $=0,946$, og SRMR på lærernivå var $\mathrm{o}, 034$, og på skolenivå var SRMR $0,021$.

2 De såkalte faktorladningene ( «factor loadings») lå på mellom o,6 og o,9. 


\section{Resultater på skolenivå}

Generelt lå intraklassekorrelasjonen for et innovativt miljø på mellom 0,111 og 0,136, distribuert ledelse på mellom 0,105 og 0,198, inkluderende undervisning på mellom 0,029 og 0,183 og kognitivt stimulerende undervisning på mellom 0,025 og 0,149. Dette er i tråd med hva vi vanligvis ser for resultater for Norge fra internasjonale studier, hvor mellom $10 \% \mathrm{og}$ $20 \%$ av variansen ligger på skolenivå.

Tabell 1 viser de direkte effektene av distribuert ledelse på et innovativt miljø, og av et innovativt miljø på læreres undervisningskvalitet. Resultatene viser en positiv effekt av distribuert ledelse på et innovativt miljø på skolenivå. Regresjonskoeffisienten, som var statistisk signifikant, var på cirka o,6, noe som reflekterer en forholdsvis sterk sammenheng. Dette kan tyde på at skoler som har en distribuert ledelse, hvor alle parter får mulighet til å påvirke skolens beslutninger, er mer innovative enn skoler som ikke har distribuert ledelse.

Tabell 1 Effekten av distribuert ledelse på et innovativt miljø, og av et innovativt miljø på læreres undervisningskvalitet. Signifikante effekter $(p<0,05)$ indikeres med ved*.

\begin{tabular}{lcc}
\hline & Lærernivå & Skolenivå \\
\hline Effekten av distribuert ledelse på et innovativt miljø & $0,387^{\star}$ & $0,557^{\star}$ \\
Effekten av et innovativt miljø på inkluderende undervisning & $0,205^{\star}$ & $0,374^{\star}$ \\
Effekten av et innovativt miljø på kognitivt stimulerende undervisning & $0,064^{\star}$ & $0,246^{\star}$ \\
\hline
\end{tabular}

Videre fant vi positive og signifikante effekter av et innovativt skolemiljø på læreres undervisningskvalitet. Effekten var en del sterkere på inkluderende undervisning (en moderat effekt på cirka o,4) enn på kognitivt stimulerende undervisning (en noe svak effekt på cirka o,2). Dette kan tyde på at skoler som er innovative har lærere som i større grad gir elevene stimulerende undervisning ved for eksempel å utfordre elevene til kritisk tenkning og problemløsning, og de har også en mer inkluderende undervisning enn mindre innovative skoler.

Mellom $10 \%$ og $15 \%$ av variansen til de avhengige variablene kan forklares med prediktorene på lærernivå, mens mellom 20 \% til $31 \%$ av variansen kan forklares på skolenivå.

Når det gjelder indirekte effekter av distribuert ledelse på læreres undervisning via et innovativt miljø, er disse vist i tabell 2. Resultatene fra 
medieringsmodellen viser at det er en signifikant indirekte effekt av distribuert ledelse på læreres inkluderende undervisning, mens den indirekte effekten av distribuert ledelse på læreres kognitivt stimulerende undervisning ikke var signifikant. Dette kan tyde på at skoler som har en distribuert ledelse, hvor alle parter får mulighet til å påvirke skolens beslutninger, også har høyere grad av inkluderende undervisning enn skoler som ikke har distribuert ledelse. I tillegg virker et innovativt miljø som en buffer på denne effekten, slik at på innovative skoler skaper distribuert ledelse mer inkluderende undervisning enn på skoler som er mindre innovative.

Tabell 2 Den indirekte effekten av distribuert ledelse på læreres undervisning via et innovativt miljø. Signifikante effekter $(p<0,05)$ indikeres med en*.

\begin{tabular}{lcc}
\hline & Lærernivå & Skolenivå \\
\hline $\begin{array}{l}\text { Indirekte effekt av distribuert ledelse på inkluderende undervisning, } \\
\text { via et innovativt miljø }\end{array}$ & $0,079^{\star}$ & $0,208^{\star}$ \\
$\begin{array}{l}\text { Indirekte effekt av distribuert ledelse på kognitivt stimulerende } \\
\text { undervisning, via et innovativt miljø }\end{array}$ & $0,025^{\star}$ & 0,137 \\
\hline
\end{tabular}

\section{Resultater på lærernivå}

På lærernivå fant vi en positiv effekt av lærernes oppfatning av distribuert ledelse på lærernes oppfatning av hvor innovativ skolen er. Regresjonskoeffisienten, som var statistisk signifikant, var på cirka 0,4 , noe som reflekterer en middels sterk sammenheng. Dette kan tyde på at lærere som opplever at de er en del av et lærerkollegium som får mulighet til å påvirke skolens beslutninger, er mer innovative enn lærere som ikke synes deres skole har en distribuert ledelse.

Videre fant vi positive og signifikante effekter av lærernes oppfatning av et innovativt skolemiljø på deres rapporterte undervisningskvalitet. Effekten var en del sterkere på inkluderende undervisning (en effekt på cirka o,2) enn på kognitivt stimulerende undervisning (en svak effekt på cirka o,1). Dette kan tyde på at lærere som oppfatter sin skole som innovativ i større grad gir elevene stimulerende undervisning ved for eksempel å utfordre elevene til kritisk tenkning og problemløsning, og de har også en mer inkluderende undervisning enn lærere som ikke oppfatter sin skole som innovativ. 
Resultatene fra modellen med indirekte effekter (medieringsmodellen) viser at det er en signifikant indirekte effekt av distribuert ledelse på både kognitivt stimulerende og inkluderende undervisning. Dette kan tyde på at skoler som har en distribuert ledelse, hvor alle parter får mulighet til å påvirke skolens beslutninger, også har høyere grad av kognitivt stimulerende og inkluderende undervisning enn skoler som ikke har distribuert ledelse. Imidlertid virker et innovativt miljø som en buffer på denne effekten, slik at på innovative skoler skaper distribuert ledelse mer kognitivt stimulerende og inkluderende undervisning.

\section{Diskusjon}

I denne studien undersøkte vi betydningen av en distribuert ledelse for et innovativt miljø på skolen, og påvirkningen av et innovativt miljø på lærernes undervisning. Vi undersøkte også om det var en indirekte effekt av distribuert ledelse på lærers undervisning via et innovativt miljø.

Generelt fant vi at distribuert ledelse var positivt relatert til et innovativt skolemiljø, og at et innovativt miljø var positivt relatert til type undervisning lærerne rapporterte. Likevel var effektene sterkere på skolenivå enn på lærernivå. En grunn til dette kan være måten distribuert ledelse og et innovativt miljø er målt og analysert på. I teoridelen beskrev vi hvordan et innovativt miljø kan måles som holdninger på individnivå (Hurt et al., 1977) eller som en karakteristikk av miljøet (Anderson \& West, 1998). I TALIS reflekterer både et innovativt miljø og distribuert ledelse karakteristika ved skolemiljø fordi lærerne blir spurt om å ta stilling til påstander ved skolene sine. Dermed hører disse konstruktene mer naturlig til på skolenivå enn på lærernivå.

Den største effekten var den av distribuert ledelse på et innovativt miljø på skolenivå. Det finnes lite tidligere forskning på akkurat denne relasjonen, men de få studiene som finnes har vist at distribuert ledelse har betydning for en suksessfull endring i skolen (Hallinger \& Heck, 2010; Harris, 2008). Et innovativt miljø er en nødvendig forutsetning for endringer, og det kan derfor være at distribuert ledelse skaper grobunn for et innovativt miljø som i sin tur kan skape endringer. 
Den svakeste effekten var den av et innovativt miljø på kognitivt stimulerende undervisning på lærernivå. Kognitivt stimulerende undervisning har vist seg å være vanskelig å måle, spesielt fordi den ofte er sterkt knyttet til det faget som denne type undervisning blir gitt i (Praetorius et al., 2018; Schlesinger \& Jentsch, 2016). I TALIS måles dette konstruktet på tvers av alle fag. I tillegg er det lærerne selv som rapporterer om sin egen undervisning, og målingene kan derfor være befestet med bias. Tidligere forskning har vist at lærere ofte svarer det de tror forventes av dem, spesielt når det gjelder undervisningskvalitet (Charalambous \& Praetorius, 2018; Schlesinger \& Jentsch, 2016). Dette kan føre til at det er mindre variasjon mellom lærernes svar, og at validiteten blir dårligere (Nilsen et al., 2020). Likevel er dette bare én mulig forklaring på den svake effekten. Det kan også være at et innovativt miljø faktisk er viktigere for inkluderende undervisning enn for kognitivt stimulerende undervisning. Uansett er betydningen av et innovativt miljø for læreres undervisning i tråd med tidligere forskning (Thurlings et al., 2015), men utvider denne til andre utfallsmål og spesielt til Norge.

Når det gjelder de indirekte effektene av distribuert ledelse på læreres undervisning via et innovativt miljø, så var disse signifikante for både lærer og skolenivå og for alle konstrukter, bortsett fra for kognitivt stimulerende undervisning på skolenivå. Det var også sterkere indirekte effekter på begge nivåer for inkluderende undervisning. Dette kan være fordi inkluderende undervisning har noe til felles med distribuert ledelse. Distribuert ledelse er også inkluderende, i det alle parter får delta i beslutningsprosesser (Ottesen, 2013). Resultatene peker også på at et innovativt miljø kan medføre at en distribuert ledelse får større betydning for læreres inkluderende undervisning. Uten et innovativt miljø, vil ikke distribuert ledelse ha like stor effekt på inkluderende undervisning. Å være innovativ betyr å være åpen for nye ideer og å være nytenkende (Janssen, 200o). Et innovativt miljø, hvor lærere får være med på beslutningsprosesser, ser ut til å fremme undervisning som støtter minoriteter og som lærer elever hvordan man med gjensidig respekt kan leve i et heterogent samfunn med stort kulturelt mangfold. Inkluderende undervisning er viktig for elevers læring (Dumont \& Istance, 2010). 


\section{Implikasjoner og bidrag}

Denne studien bidrar til forskningsfeltet innovasjon i skolen. Det finnes lite forskning på dette feltet $\mathrm{i}$ skolen, og vår studie viser at et innovativt miljø spiller en stor rolle for læreres undervisning, spesielt den type undervisning elever trenger for å utvikle såkalte «21st century skills». Videre bidrar vår studie til å ytterligere understreke betydningen av distribuert ledelse. Tidligere forskning har vist at distribuert ledelse er viktig for en suksessfull utvikling av skolen (Hallinger \& Heck, 2010; Harris, 2008; Spillane, 2012), men så vidt vi vet, har ingen vist betydningen for et innovativt miljø.

Vår studie har videre implikasjoner for skoleledere. Det er ikke bare viktig å ha en distribuert ledelse ved skolen, men det er også viktig å fremme et innovativt miljø for skolen, for dette har betydning for læreres undervisningskvalitet.

\section{Begrensninger}

Den største begrensningen ved denne studien, er at vi bruker tverrsnittsdata. Det betyr, som nevnt, at ingen kausale slutninger kan trekkes. En annen begrensning er at TALIS ikke måler elevers læringsutbytte, noe som hadde vært verdifullt for å utrede om det finnes en sammenheng mellom våre variabler og elevers læringsutbytte. Det er behov for fremtidige studier med et longitudinelt design som følger elever, lærere og skoleledere over tid, som kan undersøke effekten av distribuert ledelse på et innovativt miljø, effekten av et innovativt miljø på læreres undervisning, og hvordan denne undervisningen igjen påvirker elevers læringsutbytte.

\section{Konklusjon}

Et innovativt miljø i skolen er viktig for skolens tilpasningsevne til samfunnsendringer og for at elever skal klare seg i morgendagens samfunn. Det er derfor avgjørende å finne ut hva som fremmer et innovativt miljø i skolen, og hvilke konsekvenser et innovativt miljø i skolen har for læring. 
Vår studie finner at distribuert ledelse kan bidra til å fremme et innovativt miljø, og at et innovativt miljø i sin tur kan bidra til å fremme den typen undervisning elevene trenger for å tilegne seg kompetanser man regner med blir ekstra viktige i det 21. århundre.

\section{Referanser}

Ainley, J. \& Carstens, R. (2018). Teaching and Learning International Survey (TALIS) 2018. Conceptual Framework. OECD Education Working Papers, No. 187. https:// doi.org/https://doi.org/10.1787/799337c2-en

Anderson, N. R. \& West, M. A. (1998). Measuring climate for work group innovation: Development and validation of the team climate inventory. Journal of Organizational Behavior: The International Journal of Industrial, Occupational and Organizational Psychology and Behavior, 19(3), 235-258. https://doi.org/10.1002/ (SICI)1099-1379(199805)19:3<235::AID-JOB837>3.0.CO;2-C

Baltes, B. (2001). Psychological climate in the work setting. I N. J. Smelser \& P. B. Baltes (Red.), International encyclopedia of the social and behavioral sciences (Bd. 18, s. 12355-12359). Elsevier. https://doi.org/10.1016/Bo-08-043076-7/01437-6

Baumert, J., Kunter, M., Blum, W., Brunner, M., Voss, T., Jordan, A., Klusmann, U., Krauss, S., Neubrand, M. \& Tsai, Y.-M. (2010). Teachers' mathematical knowledge, cognitive activation in the classroom, and student progress. American Educational Research Journal, 47(1), 133-18o. https://doi.org/10.3102/0002831209345157

Blömeke, S., Scherer, R. \& Nilsen, T. (under utgivelse). School innovativeness is associated with enhanced teacher collaboration, innovative classroom practices, and job satisfaction. Journal of Educational Psychology.

Charalambous, C. Y. \& Praetorius, A.-K. (2018). Studying mathematics instruction through different lenses: Setting the ground for understanding instructional quality more comprehensively. ZDM Mathematics Education, 50(3), 355-366. https://doi.org/10.1007/s11858-018-0914-8

Dede, C. (2010). Comparing frameworks for 21st century skills. I J. Bellance \& R. Brandt (Red.), 21st century skills: Rethinking how students learn (s. 51-76). Solution Tree.

Dumont, H. \& Istance, D. (2010). Analysing and designing learning environments for the 21st century. I H. Dumont, D. Istance \& F. Benavides (Red.), The nature of learning: Using research to inspire practice (s. 19-34). OECD Publishing. https:// dx.doi.org/10.1787/9789264086487-en

Gronn, P. (2002). Distributed leadership. I K. A. Leithwood \& P. Hallinger (Red.), Second international handbook of educational leadership and administration (s. 653-696). Springer. https://doi.org/10.1007/978-94-010-0375-9 
Gustafsson, J. E. (2013). Causal inference in educational effectiveness research: A comparison of three methods to investigate effects of homework on student achievement 1. School Effectiveness and School Improvement, 24(3), 275-295. https://doi.org/10.1080/09243453.2013.806334

Hallgarten, J., Hannon, V. \& Beresford, T. (2015). Creative public leadership: How school system leaders can create the conditions for system-wide innovation. World innovation summit for education, Qatar Foundation. https://www.wise-qatar.org/ app/uploads/2019/o4/appli-rsa-2016-03-03.pdf

Hallinger, P. \& Heck, R. H. (2010). Leadership for learning: Does collaborative leadership make a difference in school improvement? Educational management administration \& leadership, 38(6), 654-678. https://doi.org/10.1177/ 1741143210379060

Hargreaves, D. H. (2003). Education epidemic: Transforming secondary schools through innovation networks. Demos.

Harris, A. (2008). Distributed leadership: According to the evidence. Journal of Educational Administration, 46(2), 172-188. https://doi.org/10.1108/ 09578230810863253

Harris, A. (2014). Distributed leadership matters: Perspectives, practicalities, and potential. Sage. http://dx.doi.org/10.4135/9781483332574

Hattie, J. (2009). Visible learning: A synthesis of over 800 meta-analyses relating to achievement. Routledge.

Hox, J. J., Moerbeek, M. \& Van de Schoot, R. (2017). Multilevel analysis: Techniques and applications. Routledge. https://doi.org/10.4324/9781315650982

Hurt, H. T., Joseph, K. \& Cook, C. D. (1977). Scales for the measurement of innovativeness. Human Communication Research, 4(1), 58-65. https://doi. org/10.1111/j.1468-2958.1977.tboo597.x

Janssen, O. (2000). Job demands, perceptions of effort-reward fairness and innovative work behaviour. Journal of Occupational and Organizational Psychology, 73(3), 287-302. https://doi.org/10.1348/o96317900167038

Jensen, R. (2020). Ledelse $i$ et distribuert perspektiv [Presentasjon]. Oslo.

Klieme, E., Pauli, C. \& Reusser, K. (2009). The pythagoras study: Investigating effects of teaching and learning in Swiss and German mathematics classrooms. I T. Janík \& T. Seidel (Red.), The power of video studies in investigating teaching and learning in the classroom (s. 137-160). Waxmann.

Kunter, M., Baumert, J., Blum, W., Klusmann, U., Krauss, S. \& Neubrand, M. (2013). Cognitive activation in the mathematics classroom and professional competence of teachers: Results from the COACTIV project. Springer. https://doi.org/10.1007/9781-4614-5149-5

McGeown, V. (1979). School innovativeness as process and product. British Educational Research Journal, 5(2), 221-235. https://doi.org/10.1080/0141192790050208 
Meld. St. 30 (2019-2020). En innovativ offentlig sektor. Kultur, ledelse og kompetanse. Kommunal- og moderniseringsdepartementet. https://www.regjeringen.no/no/ dokumenter/meld.-st.-3O-20192020/id2715113/

Muthén, L. K. \& Muthén, B. O. (1998-2017). Mplus user's guide (8. utg.). Muthén \& Muthén.

Møller, J. \& Ottesen, E. (2011). Building leadership capacity: The Norwegian approach. I T. Townsend \& J. MacBeath (Red.), International handbook of leadership for learning (s. 619-634). Springer. https://doi.org/10.1007/978-94-007-1350-5

Nilsen, T. \& Gustafsson, J.-E. (Red.). (2016). Teacher quality, instructional quality and student outcome. Relationships across countries, cohorts and time (Bd. 2). Springer. https://doi.org/10.1007/978-3-319-41252-8

Nilsen, T., Slot, P., Cigler, H. \& Chen, M. (2020). Measuring process quality in early childhood education and care through situational judgement questions: Findings from TALIS starting strong 2018 field trial. OECD Education Working Papers, No. 217. OECD iLibrary. https://doi.org/10.1787/852602c5-en

OECD. (2013). OECD skills outlook 2013: First results from the survey of adult skills. OECD iLibrary. http://dx.doi.org/10.1787/9789264204256-en

OECD. (2014). Measuring innovation in education: A new perspective. OECD iLibrary. https://doi.org/https://doi.org/10.1787/9789264215696-en

OECD. (2019). TALIS 2018 results (Bd. I). Teachers and school leaders as lifelong learners. https://doi.org/10.1787/1dobc92a-en

Ottesen, E. (2013). Leadership and inclusion: The power of dialogue. I G. M. Ruairc, E. Ottesen \& R. Precey (Red.), Leadership for inclusive education (s. 121-129): Brill Sense. https://doi.org/10.1007/978-94-6209-134-4

Patterson, M. G., West, M. A., Shackleton, V. J., Dawson, J. F., Lawthom, R., Maitlis, S., Robinson, D. L. \& Wallace, A. M. (2005). Validating the organizational climate measure: Links to managerial practices, productivity and innovation. Journal of Organizational Behavior, 26(4), 379-408. https://doi.org/10.1002/job.312

Pianta, R. C., La Paro, K. M. \& Hamre, B. K. (2008). Classroom Assessment Scoring System $^{\mathrm{m}}$ : Manual K-3: Paul H Brookes Publishing.

Praetorius, A.-K., Klieme, E., Herbert, B. \& Pinger, P. (2018). Generic dimensions of teaching quality: The German framework of three basic dimensions. ZDM Mathematics Education, 50(3), 407-426. https://doi.org/10.1007/s11858-018-0918-4

Schlesinger, L. \& Jentsch, A. (2016). Theoretical and methodological challenges in measuring instructional quality in mathematics education using classroom observations. ZDM Mathematics Education, 48, 29-40. https://doi.org/10.1007/ s11858-016-0765-O

Schlesinger, L., Jentsch, A., Kaiser, G., König, J. \& Blömeke, S. (2018). Subjectspecific characteristics of instructional quality in mathematics education. ZDM Mathematics Education, 50(3), 475-49o. https://doi.org/10.1007/s11858-018-0917-5 
Spillane, J. P. (2006). Towards a theory of leadership practice: A distributed perspective. I I. Westbury \& G. Milburn (Red.), Rethinking Schooling (s. 208-242). Routledge. https://doi.org/10.4324/9780203963180

Spillane, J. P. (2012). Distributed leadership (Bd. 4). John Wiley \& Sons.

Thurlings, M., Evers, A. T. \& Vermeulen, M. (2015). Toward a model of explaining teachers' innovative behavior: A literature review. Review of Educational Research, 85(3), 430-471. https://doi.org/10.3102/o034654314557949

Van Braak, J. (2001). Individual characteristics influencing teachers' class use of computers. Journal of Educational Computing Research, 25(2), 141-157. https://doi. org/10.2190/81YV-CGMU-5HPM-04EG

Voogt, J. \& Roblin, N. P. (2012). A comparative analysis of international frameworks for 21st century competences: Implications for national curriculum policies.

Journal of Curriculum Studies, 44(3), 299-321. https://doi.org/10.1080/00220272.2 012.668938 



\title{
KAPITTEL 4
}

\section{Hvor godt er lærere forberedt på den digitale hverdagen?}

\author{
Greta Björk Gudmundsdottir \& Julius K. Björnsson \\ Institutt for lærerutdanning og skoleforskning, Universitetet i Oslo
}

\begin{abstract}
How well are teachers prepared for digital technology in their work? In this chapter, we report on questions in the TALIS 2018 survey concerning information and communication technology (ICT). Teachers were asked how they use digital technology for student activities, how prepared they are for digital practice, and how they assess their own need for continuous professional development (CDP) related to using digital technology in a classroom setting. This chapter is divided into two main parts. In the first part, we introduce previous research in the field of digital competence. We look at how the use of digital technology has evolved in Norwegian schools and how it has been supported by various educational reforms. We also refer to frameworks and various analytical tools to better understand students' digital competence and teachers' professional digital competence (PDC). Furthermore, we consider the role of teacher education in developing teachers' and student teachers' PDC. In the second part of the chapter, we present findings from TALIS 2018. Here we highlight teachers' needs and participation in CPD, the preparations they have received in teacher education, and how they use digital technology to promote students' learning and engagement in various teaching activities. Findings on classroom management in technology-savvy environments are presented, and the general use of ICT within a Nordic comparative perspective is discussed. In conclusion, we summarize the most important findings and raise issues in need of further research.
\end{abstract}

Keywords: professional digital competence (PDC), initial teacher education (ITE), continuous professional development (CPD), digital technology

Sitering av denne artikkelen: Gudmundsdottir, G. B. \& Björnsson, J. K. (2021). Hvor godt er lærere forberedt på den digitale hverdagen? I J. K. Björnsson (Red.), Hva kan vi loere av TALIS 2018? Gode relasjoner som grunnlag for loering (Kap. 4, s. 57-86). Cappelen Damm Akademisk. https://doi.org/10.23865/noasp.123. ch4 Lisens: CC BY-NC-ND 4.o. 


\section{Introduksjon}

I dette kapittelet skal vi se på spørsmålene i TALIS 2018-undersøkelsen som dreier seg om forhold knyttet til informasjons- og kommunikasjonsteknologi (IKT). ${ }^{1}$ I TALIS 2018 ble lærere spurt om hvordan de bruker digital teknologi til elevaktiviteter, hvor forberedt de er på en digital hverdag og hvordan de vurderer eget behov for kompetanseheving og digital kompetanse for å kunne fremme elevenes læring i klasserommet ved bruk av digital teknologi.

Det er sjelden at spørsmål fra en slik undersøkelse er mer aktuelle enn nettopp nå, når undervisningspraksisen til lærere, ikke bare i Norge, men i hele verden har vært snudd på hodet grunnet covid-19 pandemien (Daniel, 2020; Ferdig et al., 2020). Mens skolene i Norge holdt stengt og videre ut på våren 2020 delvis gjenåpnet, drev lærere med nettbasert undervisning for sine elever. Nærmest over natten byttet lærere fra fysisk tilstedeværelse i et klasserom til nettbasert undervisning gjennom skjerm, tastatur og internett. Aldri før har vi sett så stor aktivitet i form av deling av digitale undervisningsressurser mellom kolleger. Mange lærere opplevde likevel en nokså bratt læringskurve samtidig som de viste enestående omstillingsevne til å gjøre det beste ut av situasjonen (Gudmundsdottir \& Hathaway, 2020). I lærerutdanningen blir også blandede læringsformer som kombinerer nettbasert undervisning med fysisk tilstedeværelse hos studentene brukt i økt grad (Atmacasoy \& Aksu, 2018; Chin et al., 2018; Crawford \& Jenkins, 2018; Gudmundsdottir \& Vasbø, 2017). Blandet læring krever stødig digital kompetanse og at de «digitale verktøyene og omgivelser som tas i bruk må ta høyde for endringer i fagene og nye kommunikasjons- og læringsvilkår mellom lærer og studenter og i de arbeidsfellesskap ansatte og studenter inngår i» ifølge Ludvigsen og Dæhlen (2020, uten sidetall).

Dette kapitlet er organisert i to hoveddeler. I første del introduserer vi tidligere forskning på feltet og konteksten vi befinner oss i. Vi ser på hvordan bruk av digital teknologi har utviklet seg i norsk skole og hvordan denne utviklingen har vært støttet av ulike reformer. Vi henviser

IKT omtales heretter som digital teknologi. 
videre til rammeverk og ulike analyseverktøy for å bedre kunne forstå elevenes digitale kompetanse og lærerens profesjonsfaglige digitale kompetanse (PfDK). Videre tar vi for oss lærerutdanningens rolle i den digitale kompetansehevingen. I andre del av kapitlet presenterer vi funn fra TALIS 2018. Her løfter vi spesielt frem læreres behov og deltakelse i faglig utviklingsarbeid, forberedelsene de har fătt i lærerutdanningen og hvordan de bruker digital teknologi for å fremme elevenes læring og bruk i ulike undervisningsaktiviteter. Funn om klasseledelse i teknologitette omgivelser og generell bruk sett i nordisk perspektiv er presentert til slutt. Avslutningsvis oppsummerer vi de viktigste funnene og reiser spørsmål som er vært å forske på videre.

\section{Utøvelse av digitale ferdigheter i skolen}

Bruk av digitale verktøy er godt etablert i norsk skole. Kunnskapsløftet (Ko6) la grunnlaget for elevenes digitale kompetanse og ferdigheter ved at Norge ble et av de første landene i verden til å definere digitale ferdigheter som en grunnleggende ferdighet for alle i skolen (Utdanningsdirektoratet, 2012; 2017). Det innebærer at alle elever, uansett trinn eller fag, skulle møte digitale ferdigheter gjennom de ulike skolefagene i grunnskolen og den videregående opplæringen.

Flere studier har siden vist at innføringen av digitale ferdigheter i skolen har vært svært varierende både når det gjelder prioriteringer i ulike kommuner og fylkeskommuner, men også når vi ser på hva gjøres på enkelte skoler innad og mellom skoler i samme kommune/fylkeskommune (Egeberg et al., 2012; Hatlevik et al., 2013; Hatlevik \& Gudmundsdottir, 2013). Evalueringen av Ko6 (Aasen et al., 2012) bekrefter også at lærere har slitt med å forstå og implementere de grunnleggende ferdighetene i undervisningen. Klausen skriver at «[d]erfor har både etablerte og nyutdannede lærere blitt mer eller mindre overlatt til seg selv for å tilegne seg kompetansen de utdanningspolitiske myndighetene fremhever betydningen av» (Klausen, 2020, s. 316). Her påpekes det også at helt siden digitale ferdigheter ble definert som grunnleggende ferdighet i lærerplanene, har det manglet kurstilbud for lærere. Til tross for dette ser vi at et stort flertall lærere er positive til potensialet teknologien har å tilby til støtte 
for undervisning og læringsaktiviteter (Gudmundsdottir \& Hatlevik, 2018). I tillegg ser vi at det ikke nødvendigvis er de yngste lærerne, som er vokst opp i et digitalt samfunn og har de mest omfattende datakunnskapene, som nødvendigvis har størst bruk av digital teknologi i klasserommet (Hatlevik et al., 2013).

Sett fra elevenes perspektiv har norske elever helt fra de var veldig små hatt god tilgang til ulike digitale verktøy (Medietilsynet, 2018). Medietilsynets Barn og medier-undersøkelser (2020) viser at norske barn og ungdommer er storforbrukere av nettbaserte tjenester. De har høy fritidskompetanse knyttet til bruk av sosiale medier, spilling og nettverksbygging, men denne kompetansen overføres ikke automatisk til bruk av digital teknologi i læringssituasjoner i skolen som bidrar til elevenes læringsutbytte. Både skoleledere og lærere har derfor et tydelig ansvar for å bistå elever med å oversette denne fritidskompetansen til meningsfulle aktiviteter i undervisnings- og læringssammenheng.

\section{Digital kompetanse styrkes i fagfornyelsen}

For å ytterligere støtte opp under hvordan lærere kan jobbe med elevers digitale kompetanse, utarbeidet Utdanningsdirektoratet et rammeverk for læreres profesjonsfaglige digitale kompetanse. Dette rammeverket operasjonaliserer ulike kunnskaps- og ferdighetsområder, som er en del av læreres profesjonsfaglige digitale kompetanse (PfDK) (Kelentrić et al., 2017) og tydeliggjør ulike kunnskaps-, ferdighets- og kompetanseaspekter knyttet til syv overordnede områder: 1) fag og grunnleggende ferdigheter; 2) skolen i samfunnet; 3) etikk; 4) pedagogikk og fagdidaktikk; 5) ledelse av læringsprosesser; 6) samhandling og kommunikasjon; 7) endring og utvikling. Rammeverket er ment til å utvikle felles forstålse av hva betegnelsen profesjonsfaglig digital kompetanse betyr; for å bidra med et nasjonalt rammeverk for lærerutdanninger å jobbe ut i fra; og ikke minst som støtte til planlegging av grunn- og videreutdanning av lærere (Kelentrić et al., 2017).

Med fagfornyelsen (LK20) (Utdanningsdirektoratet, 2020d) får digitale ferdigheter en enda mer betydelig rolle i fagene med klar forankring 
til digitale arbeidsmetoder og digitalt innhold. I den generelle beskrivelsen av digitale ferdigheter i læreplan for samfunnsfag ser vi at samfunnsfag får et særskilt ansvar for elevenes digitale kompetanse:

Digitale ferdigheiter i samfunnsfag inneber å kunne bruke digitale verktøy til å finne, behandle og navigere i digitale kjelder, utøve digital kjeldekritikk og velje ut relevant informasjon. Det handlar og om å kunne kommunisere, samarbeide og skape digitale produkt og om å følgje reglar og normer for nettbasert kommunikasjon, personvern og opphavsrett. Ferdigheita inneber og å vareta informasjons- og datasikkerheit. Utviklinga av digitale ferdigheiter går frå å utforske og bruke digitale ressursar, til å søkje og velje informasjon sjølvstendig og til å vise god digital dømmekraft når ein vel informasjon, bruker digitale ressursar og kommuniserer digitalt. (Utdanningsdirektoratet, 2020c)

I læreplan i norskfaget ser vi at digitale ferdigheter innebærer å «lage enkle sammensatte tekster til å planlegge, utvikle og redigere sammensatte tekster basert på kunnskap om hvordan de forskjellige uttrykksformene virker sammen. Utviklingen innebærer også å vise en stadig større grad av selvstendighet og dømmekraft i valg og bruk av digitale kilder»(Utdanningsdirektoratet, 2020b). I naturfag innebærer digitale ferdigheter blant annet «å kunne bruke digitale verktøy til å utforske, registrere, beregne, visualisere, programmere, modellere, dokumentere og publisere data fra forsøk, feltarbeid og andres studier» (Utdanningsdirektoratet, 2020a). Vi ser tydeligere enn før fagets egenart i disse generelle beskrivelsene av digitale ferdigheter, eller den såkalte fagdidaktiske digitale kompetansen (Gudmundsdottir \& Hatlevik, 2018; Gudmundsdottir \& Ottestad, 2016).

I International computer and information literacy study (ICILS) gjennomført i 2013 rapporterte vi at norske lærere både sa at de var generelt positive til bruk av digital teknologi i skolen, og at de hadde den grunnleggende kompetansen som måtte til for å bruke digital teknologi i klasserommet. Likevel konkluderte vi med at den sterke vektleggingen av digital kompetanse i læreplanen, sammen med at lærere behersker grunnleggende digital kompetanse, kun danner en begynnelse på at digital teknologi brukes på en variert og innholdsrik måte i elevenes læringsprosess (Gudmundsdottir \& Throndsen, 2015). 


\section{Utviklingen av profesjonsfaglig digital kompetanse (PfDK)}

Innen forskningen ser vi at begrepene elevens digitale kompetanse og lærerens profesjonsfaglige digitale kompetanse (PfDK) er operasjonalisert på ulikt vis. Gudmundsdottir og Ottestad (2016) og Gudmundsdottir og Hatlevik (2018) introduserer en overordnet tredeling av lærerens PfDK i generisk digital kompetanse, faglig/fagdidaktisk kompetanse og profesjonsrettet digital kompetanse. Denne tredelingen har vært utviklet videre, og en fjerde dimensjon lagt til som dreier seg om digital endringskraft eller «transformativ agency». Digital endringskraft tar for seg lærerens kapasitet og vilje til å bryte ut av gitte rammer (Virkkunen, 2006) og tilpasse seg eller sette i stand egne måter for å ivareta undervisning på; i dette tilfellet hvordan lærere finner nye løsninger og utfører undervisning på en ny måte (Brevik et al., 2019; Lund et al., 2019; Lund og Vestøl, 2020). En slik fremgangsmåte kan involvere motsetninger, konflikter og forstyrrelser av gitte praksiser (Haapasaari et al., 2016). En annen tilnærming ser vi hos Instefjord og Munthe (2016), som legger vekt på teknologikompetanse, pedagogisk kompetanse og sosial bevissthet som en del av deres operasjonalisering av PfDK-begrepet. Krumsvik (2014) legger til digital dannelse (bildung), og presiserer viktigheten av at slike modeller må være godt kontekstualisert i lærerutdanningen og rettet mot behovet fremtidige lærere møter i praksisfeltet.

Med utgangspunkt i en sammenfatning av ulike europeiske rammeverk på digital kompetanse har en gruppe forskere fra OsloMet, University of Limerick, University of Malta, Universitetet i Oslo og University of Valencia kommet frem til et analytisk verktøy som kalles PEAT (Dicte, 2019). Rammeverket består av fire dimensjoner, som alle inngår i og er viktige deler av læreres PfDK. Den første er pedagogisk dimensjon (P for pedagogical). Når vi bruker digital teknologi i klasserommet er pedagogiske aspekter viktige; som hvordan og hvilke arbeidsmåter vi legger opp til ved bruk av teknologien. Her er det klar kobling til for eksempel klasseledelsesaspekter og differensiering som en del av digital praksis, men også hvordan vi designer undervisningsøkter og tar i bruk digital teknologi. Neste dimensjon er den etiske (E for ethical), som er tett knyttet til digital 
dømmekraft - dvs. personvern og opphavsrett, kildekritikk og det å være sosial på nett samt digitalt medborgerskap. Den tredje er holdninger (A for attitudes) til teknologien, altså viljen og motivasjonen til å ta i bruk og prøve nye metoder som innebærer digital teknologi. Den fjerde og siste dimensjonen er den tekniske ( $\mathrm{T}$ for technical), dvs. infrastruktur og tilgang til programvare, samt ren teknisk kompetanse (Dicte, 2019; Gudmundsdottir \& Hathaway, 2020). Disse fire dimensjonene kan brukes til å analysere digital praksis i klasserommet og få frem ulike aspekter i læreres PfDK. Modellen kan også definere viktige innsatsområder i lærerutdanningen og utviklingen av lærerstudenters PfDK. I tillegg er det verdt å nevne TPACK-modellen (Koehler \& Mishra, 2005) som er mye brukt av både lærere og utdanningsforskere. TPACK står for «technological, pedagogical, and content knowledge», men mangler både holdningsaspektet og den etiske dimensjonen som PEAT har lagt til i sitt analytiske verktøy. Disse dimensjonene mener vi er svært viktige i norsk kontekst, hvor elevers og læreres digitale dømmekraft samt lærerens holdning til digital teknologi og egen profesjonsutvikling står som sentral del av profesjonsfaglig digital kompetanse.

Mye av den tidligere forskningen har påpekt potensialet i bruk av digital teknologi i klasserommet (Brevik \& Davies, 2016; Livingstone, 2012; Punie \& Ala-Mutka, 2007). Albion et al. (2015) presiserer også viktigheten av systematisk tilnærming i både lærerutdanningen og etter- og videreutdanning av lærere, som legger vekt på pedagogiske praksiser som utnytter potensialet av digital teknologi i istedenfor isolerte innovasjoner drevet av ildsjeler. Nyere forskning fra Norge bekrefter at læreres bruk av teknologi i klasserommet ofte foregår i form av tradisjonell «transmissiv» undervisning med begrenset elevdeltakelse, hvor diskursen dreier seg primært om praktiske og tekniske ting (Blikstad-Balas \& Klette, 2020). Slike funn ser vi også i Gudmundsdottir og Throndsen (2015), som viser beskjeden bruk i skolen, og i en studie som ble utført i første ukene av skolestenging under covid-19-pandemien våren 2020 (Gudmundsdottir \& Hathaway, 2020). Der spurte forskerne hvor godt forberedt lærere var for nettbasert undervisning. Med andre ord, hvor forberedt var lærere på å utføre fjernundervisning og bruke digitale løsninger på heltid? Studien konkluderer med at i de første ukene var det de tekniske dimensjonene lærerne er svært 
opptatt av, dvs. om verktøyene fungerer eller om de har tilgang til nødvendig programvare. Studien viser videre at lærerne reflekterte i noe mindre grad om pedagogisk bruk av teknologien. Det var likevel de etiske sidene ved bruk av teknologien som var sjeldnest nevnt, dvs. problemstillinger rundt for eksempel personvern, opphavsrett og digitalt medborgerskap (Gudmundsdottir \& Hathaway, 2020).

Samlet viser de ulike studiene at det fremdeles er en del lærere som har begrenset erfaring med nettbasert undervisning og i å bruke digital teknologi på en kreativ og pedagogisk måte sammen med elevene sine. Dette til tross for høye nasjonale ambisjoner for utvikling av elevers digitale kompetanse.

\section{Lærerutdanningens rolle $\mathrm{i}$ kompetansehevingen}

Det vi allerede vet, er at det er store forskjeller i den digitale praksisen i norsk skole (Egeberg et al., 2012; Hatlevik et al., 2013; Fjørtoft et al., 2019). Både tilgang og bruk av digital teknologi er variert, men det varierer også i hvor stor grad skolene prioriterer og legger til rette for bruk av digital teknologi. Dette opplever og uttrykker lærerstudenter som er i praksis (Gudmundsdottir \& Hatlevik, 2020). Vi vet også at en stor del av elevene har vist seg å slite med digitale oppgaver som samsvarer kompetansemålene i skolen. Dette viste ICILS 2013-studien, da ferdigheter som var testet av 9.-klassinger ble sammenlignet med kompetansemålene i skolen. Omtrent en av fire elever skåret da på laveste nivå på ferdighetsskalaen i ICILS-undersøkelsen, noe som oversatt til kompetansemålene betyr at elevene skårer under de kravene som stilles i skolen (Hatlevik \& Throndsen, 2015).

Den ulike digitale praksisen, som vi også ser internasjonalt, har vært forbundet med forskjellige årsaker og forklaringer både nasjonalt og internasjonalt. For eksempel har den vært koblet til ulik prioritering og støtte fra skoleledelsen, og hvordan bruk av teknologi er definert i læreplaner eller styringsdokumenter (Gil-Flores et al., 2017). Når vi ser spesifikt på lærerens egenskaper trekker Rienties et al. (2016) frem holdninger til teknologien («technology acceptance»). Uluyol og Şahin (2016) ser på 
lærerens motivasjon, og Voet og De Wever (2017) påpeker hvor viktig det er med faglig digital kompetanse. Andre peker på lærerens mestringsopplevelse («self-efficacy») knyttet til digital teknologi (Hatlevik, 2017; Tondeur et al., 2017) og hvor viktig det er å ha rollemodeller i skolen og i lærerutdanningen (Gudmundsdottir \& Hatlevik, 2020; Tondeur et al., 2018). Uavhengig av forklaringen på den ulike praksisen er det tydelig at lærere i tidligere runder av TALIS-undersøkelsen (OECD, 2010, 2014) har rapportert at de ønsker økt digital kompetanse. Senere i dette kapitlet vil vi se om lærerne i TALIS 2018 fortsatt uttrykker samme ønske.

Lærerutdanningen har et ansvar å utdanne fremtidige lærere og tilby videreutdanning som sikter på videreutvikling av PfDK, slik at lærere er både forberedt til å bidra til elevenes digitale kompetanse, men også til å heve egen kompetanse. Studier har vist at lærerstudentene ikke opplever at de er godt nok forberedt på den digitale praksisen i skolen (Gudmundsdottir \& Hatlevik, 2018, 2020; Lund et al., 2014). Både Instefjord og Munthe (2016, 2017) og Røkenes og Krumsvik (2014) bekrefter manglende arbeid med digital kompetanse i lærerutdanningens læreplaner og i undervisningspraksiser (Hjukse et al., 2020).

Hjukse et al. (2020), som ser på digitaliseringen i grunnskolelærerutdanningen, betrakter videre hvilken betydning faggruppetilhørighet har på lærerutdanneres arbeid med PfDK. De finner at det er sammenheng mellom fag og i hvor stor grad lærerutdannere jobber med utviklingen av PfDK med sine studenter. I tillegg finner de at en del av den profesjonsrettede digitale kompetansen er lite synlig i lærerutdanningen. Studien bekrefter tidligere forskning, som viste at dårlig forankring av PfDK i lærerutdanningens emneplaner fortsatt er aktuell (Tømte et al., 2013; Gudmundsdottir et al., 2014; Gudmundsdottir \& Hatlevik, 2018). Hjukse et al. (2020) løfter i sin konklusjon opp profesjonsrettede temaer som er særlig viktige for lærerutdanning å jobbe videre med når det gjelder bruk av digital teknologi i fagene. Dette kan være temaer som klasseledelse i teknologirike omgivelser og differensiering og tilpasset opplæring ved hjelp av teknologi, men også temaer knyttet til digital mobbing og krenkelser på nett samt digitalt medborgerskap.

Kunnskapsdepartementet har de siste årene satset på utviklingen av PfDK i grunnskolelærerutdanningen og tildelt midler til et betydelig 
kompetanseløft (Daus et al. 2019; Nagel, 2021). I tillegg har ProTed senter for fremragende lærerutdanning ved Universitetet i Oslo og Universitetet i Tromsø hatt digitale læringsomgivelser som et særegent satsingsområde. En av utfordringene ved satsinger som disse er likevel hvordan bidra til synergieffekt mellom og på tvers av institusjoner, slik at erfaringer og opparbeidet kunnskap videreformidles og kommer til nytte for flere lærerutdanningsmiljøer enn de som opprinnelig er involvert. Noen miljøer, som har det til felles at de går på tvers i universitetenes hierarkier og kobler digitalisering, pedagogikk og læring, er verdt å følge med på. Dette er for eksempel den tverrfaglige utviklingsenheten $e D U^{2}$ ved Universitetet i Sørøst-Norge og RESULT ${ }^{3}$ ved Universitetet i Tromsø, som har eksistert ganske lenge og opererer på tvers i organisasjonen. Nylig kom CeDiT, ${ }^{4}$ eller Senter for digital transformasjon ved Universitetet i Agder, på banen, og så har vi Senter for digitalisering ${ }^{5}$ ved BI for å nevne noen. Disse er ikke rettet spesielt mot lærerutdanningene, men har til felles at de illustrerer både synergieffekter og spredning, nettverksbygning og flerfaglighet som er svært viktig på digitaliseringsfeltet.

Nå har vi lagt frem en situasjonsbeskrivelse fra tidligere forskning om noe av det vi vet om utviklingen av digital kompetanse på utdanningsfeltet. Vi har også vært innom hvordan digitale ferdigheter gjenspeiles i læreplaner, og hvor viktig PfDK er i lærerutdanningen. I det følgende avsnittet presenterer vi funnene fra TALIS 2018 knyttet til bruk av digital teknologi, og hvordan lærere svarte på spørsmål om digital kompetanse og hvor godt forberedt de opplevde at de er for en digital skolehverdag. Før disse tallene presenteres er det viktig å huske at svarene er hentet inn våren 2018. Hadde TALIS blitt gjennomført i 2020, hadde lærere høyst sannsynlig meldt om høyere grad av digital kompetanse og mer utstrakt bruk av digital teknologi grunnet omfattende endringer i deres undervisningspraksis som følge av covid-19-pandemien.

\footnotetext{
https://edu.usn.no/omoss/

https://result.uit.no/om-oss-og-kontaktinformasjon/

https://www.uia.no/forskning/samfunnsvitenskap/cedit-senter-for-digital-transformasjon

https://www.bi.no/forskning/sentre-forskningsgrupper-og-andre-initiativ/senter-for-digitalisering/
} 


\section{Hva viser TALIS 2018?}

I denne delen presenterer vi funn fra TALIS 2018 knyttet til bruk av digital teknologi og lærerens deltakelse og behov for kompetanseheving.

\section{Behov for faglig utvikling}

For å få kunnskap om lærernes behov for faglig utvikling og deltakelse i etter- og videreutdanning ble lærerne bedt om å vurdere egne behov for faglig utvikling innen området IKT-ferdigheter til bruk $i$ undervisning. Lærerne vurderte egne utviklingsbehov på skala fra stort behov til ikke noe behov. Svarene er svært interessante med tanke på den siste tiden, der alle lærere har måttet bytte om til å i større grad undervise på digitale flater.

Vi ser på svarene at 7 av 10 norske lærere vurderer at de har stort eller visst behov for faglig utvikling knyttet til bruk av digital teknologi i undervisningen, mens $20 \%$ av lærerne svarer at de har lite behov og mindre enn $10 \%$ svarer at de ikke har noe behov. Samsvarende høye tall har vi sett i tidligere TALIS-undersøkelser fra 2008 og 2013. Til tross for etterutdanningstilbud knyttet til PfDK og økt bruk av digital teknologi i undervisningen er behovet fortsatt stort, og vi ser et kontinuerlig behov for faglig utvikling knyttet til bruk av digital teknologi i undervisningen. Dette kan til dels skyldes at den teknologiske utviklingen foregår svært raskt. Det introduseres stadig nye digitale løsninger og nye arbeidsmåter i bruk av digital teknologi i undervisning og til læring som vedlikeholder dette behovet.

Når vi sammenligner svarene fra lærerne i de nordiske landene ser vi at $22 \%$ av norske og svenske lærere melder om stort behov for faglig utvikling i bruk av digital teknologi i undervisningen og ligger litt over OECD gjennomsnittet (se tabell 1). Det er meldt inn noe lavere behov hos islandske og finske lærere, og aller minst behov har de danske lærerne. I Danmark er det kun 1 av 10 lærere som melder om stort behov for faglig utvikling i bruk av digital teknologi i undervisningen.

Analyserer vi svarene ut fra lærerens erfaring, ser vi tydelig at behovet er stort til tross for lang erfaring fra skolen (figur 1). Her ser vi at $80 \%$ av de som har over 20 års erfaring fra skolen har noe eller stort behov, mens 
Tabell 1 Prosentandel nordiske lærere som melder om stort behov for kompetanseheving i bruk av digital teknologi i undervisningen.

\begin{tabular}{ll}
\hline Danmark & $11 \%$ \\
Finland & $19 \%$ \\
Island & $21 \%$ \\
Norge & $\mathbf{2 2} \%$ \\
\hline Sverige & $22 \%$ \\
OECD gjennomsnitt & $\mathbf{1 8 \%}$ \\
\hline
\end{tabular}

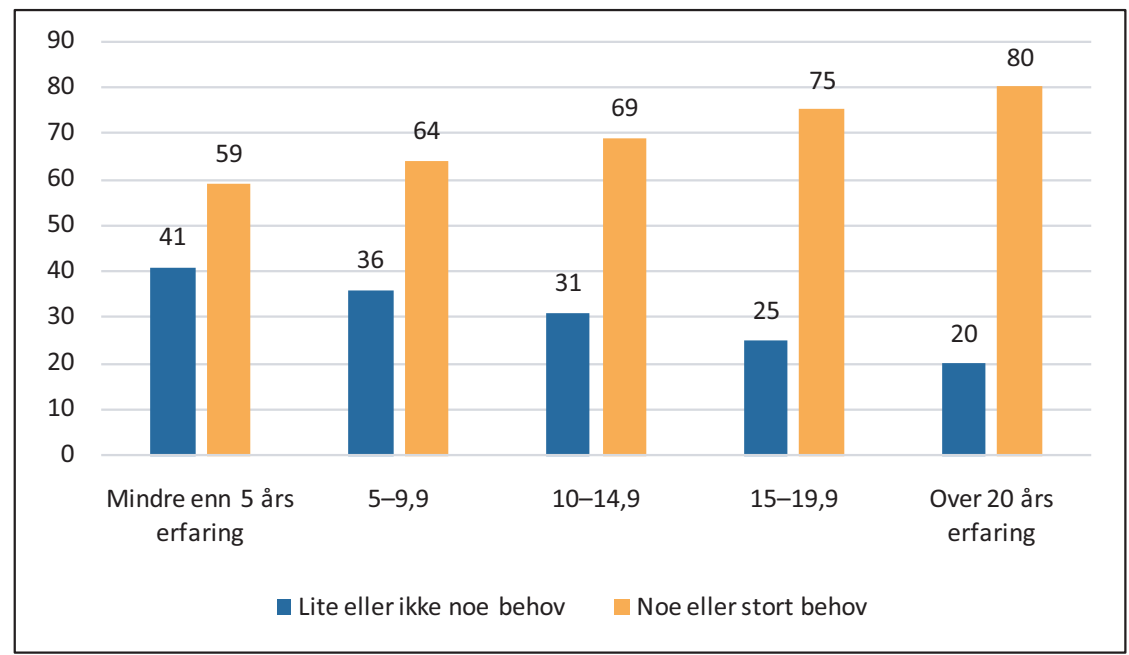

Figur 1 Læreres erfaring fra skolen (i år) og behov for faglig utvikling i bruk av digital teknologi i undervisningen.

nærmere 6 av 10 av lærerne med minst erfaring (mindre enn 5 år) melder om det samme store behovet. Dette kan skyldes stor vekt på digital kompetanse i norsk skole, noe som kan påvirke at så stor del av lærerne melder om behov for kompetanseutvikling.

\section{Behov i alle aldersgrupper}

Når vi ser på svarene i de ulike aldersgruppene som svarer på TALIS 2018-undersøkelsen kan vi si at generelt melder lærere i alle aldersgrupper fra om stort eller visst behov for faglig utvikling og kompetanseheving i 
bruk av digital teknologi i undervisningen (se figur 2). Dette gjelder $74 \%$ av de over 60 år, mens 8 av 10 lærere (81 \%) av de mellom 50 og 59 år melder om samme behov for faglig utvikling. Det kan bety at de som nærmer seg pensjonsalder (de over 60 år) ikke vurderer behovet like akutt som de som har en del år foran seg og ønsker å holde seg oppdatert på bruk av digital teknologi i undervisningen. I aldersgruppen mellom 40 og 49 er det $76 \%$ av lærerne og $61 \%$ av de mellom 30 og 39 som svarer at de har et visst behov eller stort behov.

Det er noe oppsiktsvekkende at også over halvparten av de yngste lærerne $(55 \%)$ melder om et visst eller stort behov, all den tid de har hatt sin skolegang og gjennomført lærerutdanningen etter at Ko6 ble innført med satsing på digitale ferdigheter. Dette kan nettopp bety at det er grunnet viktigheten av digital kompetanse i norsk læreplan at også de yngste fortsatt har behov for kompetanseheving. Økt bruk av digital teknologi kan også føre til økt behov og/eller interesse for å lære mer. Samlet sett forteller disse tallene oss at det er stort behov for faglig utvikling hos lærere når det gjelder PfDK, og at dette er noe lærerutdanningen trenger å jobbe videre med.

Delt på kjønn ser vi også at det er noen flere kvinnelige lærere (26 \%) som melder fra om at behovet for faglig utvikling i bruk av digital

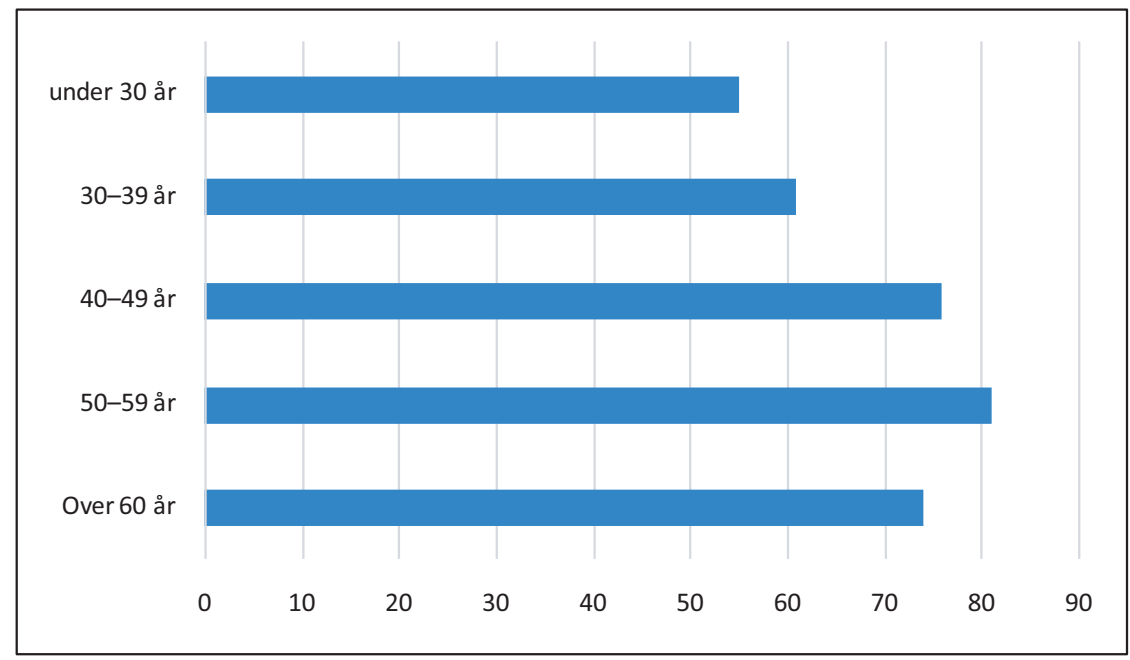

Figur 2 Prosentandelen lærere som melder behov for faglig utvikling og kompetanseheving i bruk av digital teknologi i undervisning, delt etter alder. 


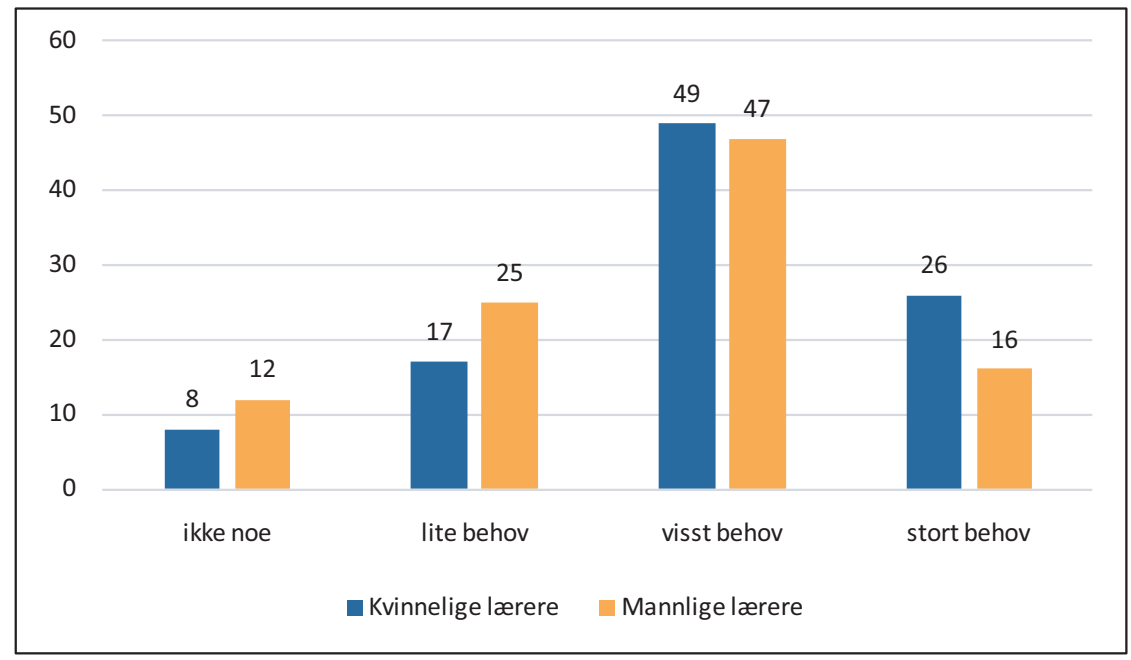

Figur 3 Prosentandelen lærere som melder behov for faglig utvikling knyttet til bruk av digital teknologi i undervisning.

teknologi i undervisningen er større, enn deres mannlige kollegaer (16\%). Nærmere halvparten av begge kjønn melder om et visst behov for en slik faglig utvikling (se figur 3 ).

Samlet sett viser disse tallene at det å bruke digital teknologi til undervisning er noe lærere av begge kjønn, $i$ alle aldre og uansett arbeidserfaring $ø$ nsker faglig utvikling på. Når vi ser tilbake på tidligere TALIS-undersøkelser ser vi det samme behovet, noe som betyr at dette har vært og er fortsatt et vedvarende behov (OECD, 2010, 2014).

Tidligere har norske lærere svart at metodene de tilegner seg teknologien på er prøving og feiling, og at de heller ønsker kollegaveiledning enn kurs og kompetansetiltak utenfor skolens vegger (Egeberg et al., 2012; Hatlevik et al., 2013). Dette kan bety at heller enn å legge inn diverse kurs, er det viktig å legge til rette for at kollegaer kan prøve ut sammen, veilede hverandre og ta i bruk digital teknologi i undervisningen i trygge og kjente omgivelser. Tiltak for bruk av digital teknologi må treffe både det pedagogiske og det mer fagspesifikke i undervisnings- og læringssammenheng (Hjukse et al., 2020). Vi ser også at endringsviljen hos lærere er noe som er spesielt viktig å bidra til på dette feltet (Brevik et al., 2019; Lund et al., 2019). Uansett krever faglig utviklingsarbeid og læres kompetanseheving innen PfDK målrettet og kontinuerlig innsats. 


\section{Deltakelse i faglig utvikling}

Til tross for stort behov for faglig utvikling og økt PfDK er antallet lærere som oppgir at de har deltatt på kompetansehevende aktiviteter de siste 12 månedene begrenset. Vi ser likevel at lærere som deltar i faglige aktiviteter knyttet til bruk av digital teknologi i undervisning øker fra TALIS 2013 til TALIS 2018. I 2013 er det $37 \%$ av lærerne som deltar i faglig utvikling knyttet til bruk av digital teknologi i undervisning, mens 6 av 10 lærere $(58 \%)$ deltok i aktiviteter rekatert til digital teknologi i 2018. Dette betyr ikke nødvendigvis at lærere står mindre rustet til å bruke digital teknologi i undervisningen enn de gjorde i 2013, men at lærere i økt grad merker behovet for digital kompetanse i sin yrkesutøvelse.

Som det fremgår av tabell 2 ser vi at det er et høyt antall lærere som har deltatt i faglige aktiviteter knyttet til bruk av digital teknologi $i$ undervisning i alle aldersgrupper, uansett om lærere har lang eller kort undervisningserfaring. Deltakelsen spanner fra 54-61 \% av lærerne som svarer positivt på at de har deltatt i aktiviteter relatert til bruk av digital teknologi i egen undervisning. De lærerne som svarer positivt på spørsmålet er flest i gruppene av lærere med kortest og lengst tid i yrket, men forskjellen er likevel liten mellom ulike aldersgrupper og undervisningserfaring. Slik ser vi at $61 \%$ av lærere med under 5 års erfaring og $60 \%$ av lærere med 20 års undervisningserfaring eller mer har deltatt i slike aktiviteter de siste 12 månedene. Det er også flertallet av andre lærere som svarer positivt på spørsmålet, og mellom 55 og 56 \% av lærere med mer enn 5 års erfaring og inntil 20 år svarer positivt på at de har deltatt i slikt utviklingsarbeid. Noe større forskjeller fremkommer hvis vi ser på svarene delt på kjønn.

Tabell 2 Deltakelse i faglig utviklingsaktivitet knyttet til bruk av digital teknologi i undervisning i de siste 12 månedene.

\begin{tabular}{llll}
\hline Lærererfaring (antall år) & $\%$ & Alder & $\%$ \\
\hline Mindre enn 5 & 61 & Under 30 år & 59 \\
$5-9,9$ & 56 & $30-39$ àr & 59 \\
$10-14,9$ & 55 & $40-49$ år & 58 \\
$15-19,9$ & 56 & $50-59$ år & 54 \\
Over 20 & 60 & Over 60 år & 61 \\
\hline
\end{tabular}


Da viser det seg at flere mannlige (63,5\%) enn kvinnelige (55\%) lærere har deltatt på slike aktiviteter.

Når vi sammenligner gruppen lærere som har deltatt og de som ikke har deltatt i faglige aktiviteter i bruk av digital teknologi i undervisning og som melder om at de (fortsatt) har behov for faglig utvikling, ser vi at det er tilnærmet ingen forskjell på de to gruppene (figur 4). Omtrent $70 \%$ av alle lærerne melder om noe og stort behov for faglig utvikling uansett om de har deltatt i faglig utvikling på området det siste året. Det ser derfor ikke ut som den typen faglig utviklingsarbeid knyttet til bruk av digital teknologi i undervisning som de deltar på, slår an eller oppleves som nyttig nok i undervisningssammenheng. Det er også mulig at faglig utviklingsarbeid har åpnet for nye spørsmål, eller at den ikke var relevant eller omfattende nok for å møte behovet for kompetanseheving i bruken av digital teknologi i undervisningen.

Når vi ser på lærere som melder om behov (noe eller stort) for faglig utvikling i bruk av digital teknologi i undervisningen ser vi at det er ulike grunner som hindrer dem i å delta i slike aktiviteter. For eksempel sier $38 \%$ av lærerne at slike aktiviteter kolliderer med arbeidsplanen deres. Det er også et kostnadsspørsmål når 33 \% svarer at for høye kostnader hindrer deltakelse. En del lærere sier også at det ikke oppleves som det er

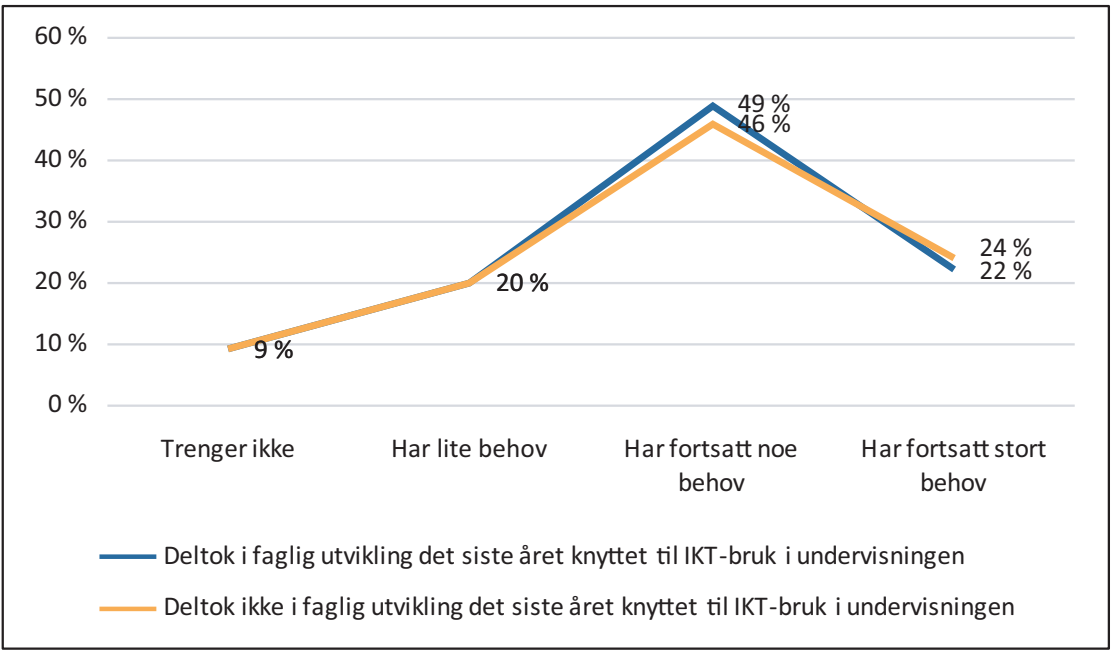

Figur 4 Læreres deltakelse i faglig utvikling knyttet til bruk av digital teknologi i undervisningen delt på de som deltok i slike aktiviteter og de som ikke gjorde det de siste 12 månedene. 
insentiver til å delta i slike aktiviteter (28\%) og at det er manglende støtte å få fra arbeidsgiver (22\%).

Nå har vi sett på lærerens deltakelse i faglig utviklingsarbeid, det pågående behovet og hva som hindrer dem i å delta. Da er det relevant å se på hvordan lærerutdanningen forbereder lærere til å jobbe med digital teknologi, og hvorvidt digital teknologi og relaterte temaer var en del av den formelle utdanningen lærerne gjennomførte.

\section{PfDK som en del av lærerutdanningen?}

Lærerne ble spurt om følgende «fag»: IKT, teknologi, grafikk, design, digitale medier og lignende (heretter IKT-fag) var en del av den formelle lærerutdanningen de tok. Mindre enn $10 \%$ av de nyutdannede (med mindre enn 5 års erfaring fra skolen) svarer at IKT-fag var en del av deres formelle utdanning, mens 1 av 5 lærere med 15-20 års erfaring svarte at dette hadde vært en del av deres formelle utdanning. Det samme gjelder hvis vi ser på lærerens alder. De yngste lærerne har ikke IKT-fag som en del av sine fag i lærerutdanningen, og i mindre grad enn eldre lærere. Generelt sett opplever lærerne at IKT-fag i svært liten grad er en del av den formelle utdanningen de har fått.

Dette kan for eksempel skyldes at IKT eller digital teknologi vanligvis ikke er et enkeltstående fag eller emne på lærerutdanningen, men at det som en grunnleggende ferdighet i skolen anses som viktig del av alle fag og fagområder i lærerutdanningen. Dette kan være noe av forklaringen for høyt behov for faglig og profesjonell utvikling blant alle aldersgrupper av lærere på denne tematikken.

Når lærerne ble spurt om bruk av digital teknologi $i$ undervisningen var en del av lærerutdanningen de tok, ser vi stor forskjell i svarene opp mot hvor lang erfaring lærerne hadde bak seg i skolen, som vi kan anta at sier noe om hvor lang tid det er siden de tok lærerutdanningen. $65 \%$ av lærerne med minst erfaring, dvs. under fem år, svarer at bruk av digital teknologi i undervisningen var en del av lærerutdanningen. Videre svarte kun $24 \%$ av lærerne med over 20 års erfaring det samme (se figur 5). Svarene viser at digital teknologi i undervisningen er i økt grad blitt en del av forberedelsene lærere får i lærerutdanningen. 


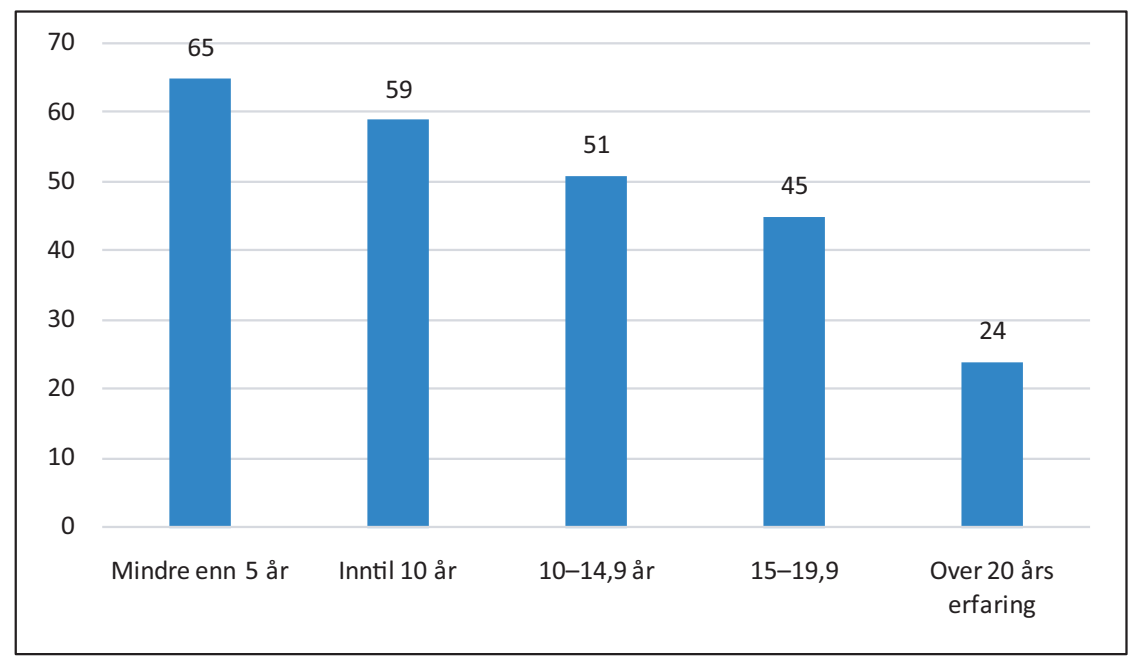

Figur 5 Prosentandel lærere som svarer at bruk av digital teknologi var en del av lærerutdanningen deres, kategorisert etter lærererfaring i antall år.

Det som også er interessant, er at størsteparten av de nyutdannete lærerne svarer at digital teknologi var en del av den formelle utdanningen deres. Disse lærerne er som oftest de yngste som svarte på TALISspørreskjemaet, og de som har hatt digitale ferdigheter som en del av egen grunnopplæring. Likevel opplever de at de ikke har tilstrekkelig digital kompetanse som lærere.

Hvis vi ser på tall fra de nordiske landene på hvor godt forberedt lærere anser seg å være til bruk av digital teknologi i undervisningen, ser vi at svært mange lærere opplever at de ikke er særlig godt forberedt. Når vi ser nærmere på prosentandelen av lærerne som svarte at de var veldig godt eller godt forberedt til å bruke digital teknologi i undervisningen, ser vi at prosentdelen som svarer slik er lavere i alle de nordiske landene enn OECD-gjennomsnittet (se tabell 1).

Tabell 3 Prosentandel nordiske lærere som er veldig godt eller godt forberedt til bruk av digital teknologi i undervisningen.

\begin{tabular}{ll}
\hline Danmark & $40 \%$ \\
Finland & $21 \%$ \\
Island & $26 \%$ \\
Norge & $\mathbf{3 6 \%}$ \\
Sverige & $37 \%$ \\
OECD gjennomsnitt & $\mathbf{4 3 \%}$ \\
\hline
\end{tabular}


Det er noe overraskende at ikke flere føler seg bedre forberedt sett i sammenheng med figur 5, som viser at lærerutdanningen har prioritert bruk av digital teknologi i sine studieprogrammer. Det er likevel slik at det er store forskjeller på hvordan digital teknologi i lærerutdanningen er integrert i ulike fag/emner og hvordan det satses på PfDK, som drøftet tidligere.

\section{Læringsfremmende bruk av digital teknologi}

Lærerne ble spurt om de bruker digital teknologi (for eksempel datamaskiner, nettbrett og interaktive tavler) for å fremme elevenes læring (se tabell 4). På svarene ser vi noe forskjell mellom lærere med lang erfaring og de med mindre erfaring fra skolen. Omtrent 1 av 3 lærere med inntil 10 års undervisningserfaring sier at de bruker digital teknologi mye, mens de med lengst erfaring fra skolen bruker digital teknologi minst. Det er derfor tydelig forskjell på hvor lenge respondentene har vært lærere og deres bruk av digital teknologi. Dette er koblet til lærerens alder, da de yngste bruker teknologien mest, mens de eldste bruker den minst for å fremme elevenes læring. Det finnes ikke forskjell på mannlige og kvinnelige lærere i hvor mye de bruker digital teknologi for å fremme elevers læring.

Tabell 4 Prosentandel lærere som bruker digital teknologi i svært stor grad for å fremme elevenes læring.

\begin{tabular}{lcc}
\hline Læreres alder & $\begin{array}{c}\text { Bruker digital teknologi } i \text { svært } \\
\text { stor grad for å fremme elevenes } \\
\text { læring }\end{array}$ & $\begin{array}{c}\text { Bruker digital teknologi } i \text { noen } \\
\text { grad for å fremme elevenes } \\
\text { læring }\end{array}$ \\
\hline Under 30 år & 34 & 21 \\
$30-39$ ar & 25 & 28 \\
$40-49$ àr & 18 & 32 \\
$50-59$ ar & 11 & 39 \\
60 år og eldre & 11 & 44 \\
\hline Læreres erfaring & & \\
\hline Mindre enn 5 år & 28 & 24 \\
Inntil 10 år & 26 & 26 \\
$10-14,9$ år & 19 & 33 \\
$15-19,9$ & 17 & 35 \\
Over 20 års erfaring & 12 & 41 \\
\hline
\end{tabular}


Til tross for at de yngste lærerne bruker teknologien mest, ser det ut som at digital teknologi brukes i stor grad av mange lærere. Det var svært få lærere som svarte at de aldri brukte digital teknologi. Vi ser i tabell 4 at bruken av digital teknologi for å fremme elevenes læring er godt etablert blant norske lærere. Det kan nettopp være derfor at de ønsker mer faglig utvikling på området, for å få nye ideer og skape variasjon i sine arbeidsmetoder med digital teknologi.

Fire av ti lærere som svarer at de ikke bruker digital teknologi for å fremme elevenes læring i det hele tatt melder også om at de har stort behov for faglig utvikling i bruk av digital teknologi i undervisningen, mens $15 \%$ av lærerne som bruker digital teknologi for å fremme elevenes læring mye, melder om stort behov for faglig utvikling.

Når vi ser nærmere på lærerne som bruker digital teknologi i undervisningen $i$ svoert stor grad, ser vi at godt over halvparten av de samme lærerne (75\%) lar elevene ofte eller alltid bruke digital teknologi i prosjektarbeid. Det samme gjelder når de lar elevene bruke digital teknologi til vanlig skolearbeid i timene (class work). Da er det $55 \%$ av lærerne som bruker digital teknologi ofte, mens $16 \%$ bruker det alltid (se tabell 5).

Tabell 5 Prosentandel lærere som bruker digital teknologi i prosjektarbeid og i undervisningen.

\begin{tabular}{lcc}
\hline & I prosjektarbeid & I undervisningen (dvs. i timene) \\
\hline Aldri eller nesten aldri & 4 & 2 \\
Av og til & 22 & 27 \\
Ofte & 46 & 55 \\
Alltid & 29 & 16 \\
\hline
\end{tabular}

Av denne tabellen ser vi at digital teknologi er en integrert del av lærerens arbeidsmåte i undervisningen og når elevene jobber med prosjekter. Det er svært få lærere som svarer at de aldri eller nesten aldri bruker digital teknologi i undervisningen eller til elevenes prosjektarbeid.

\section{Klasseledelse og digital teknologi}

Når vi sammenligner lærere som svarer at de alltid og aldri bruker digital teknologi til elevenes prosjektarbeid i timene og svarer på spørsmålene 
om uro og forstyrrelser i klassen, ser vi en del interessante aspekter (tabell 6). Lærerne som aldri bruker digital teknologi i elevenes prosjektarbeid sliter mer med uro i timene enn de som alltid bruker digital teknologi til elevenes prosjektarbeid. Dette gjelder ved oppstart av time, ved elevenes avbrytelse av undervisning og forstyrrende bråk i klassen. Det er noe mindre forskjeller i vanlig skolearbeid i timene når digital teknologi er brukt. Ved oppstart av time svarer $12 \%$ av lærerne som alltid bruker digital teknologi i undervisningen at de er enig at det tar tid før de får roet ned elevene, mens samsvarende tall for lærerne som aldri bruker digital teknologi i undervisningen er $21 \%$. Av dette kan vi konkludere at elevenes bruk av digital teknologi i undervisningen og i prosjektarbeid ser ikke ut til å forårsake økt uro og avbrytelser i norske klasserom, ifølge lærerne.

Tabell 6 Prosentandel lærere som svarer om uro og forstyrrelser når digital teknologi er brukt i skolearbeid i timen.

\begin{tabular}{lccc}
\hline & $\begin{array}{c}\text { Enig at ved } \\
\text { oppstart av } \\
\text { timen, tar det } \\
\text { ganske lang tid } \\
\text { før jeg får roet } \\
\text { elevene }\end{array}$ & $\begin{array}{c}\text { Enig at vi } \\
\text { mister ganske } \\
\text { mye tid fordi } \\
\text { elevene avbryter } \\
\text { undervisningen }\end{array}$ & $\begin{array}{c}\text { Enig at det er } \\
\text { mye forstyrrende } \\
\text { bråk i klassen }\end{array}$ \\
\hline $\begin{array}{l}\text { Bruker alltid digital teknologi } \\
\text { i elevenes prosjektarbeid }\end{array}$ & 13 & 19 & 27 \\
\hline $\begin{array}{l}\text { Bruker aldri digital teknologi } \\
\text { i elevenes prosjektarbeid }\end{array}$ & 19 & 30 & 21 \\
\hline $\begin{array}{l}\text { Bruker alltid digital teknologi } \\
\text { til skolearbeid i timen }\end{array}$ & 12 & 23 & 22 \\
\hline $\begin{array}{l}\text { Bruker aldri digital teknologi } \\
\text { til skolearbeid } \mathrm{i} \text { timen }\end{array}$ & 21 & 26 & \\
\hline
\end{tabular}

\section{Sammenligning av nordiske land og skoleledere}

I TALIS 2018 ble lærerne spurt i hvor stor grad de bruker digital teknologi for å fremme elevenes læring. Når vi sammenligner de nordiske landene, ser vi at danske lærere er de som desidert bruker digital teknologi mest (se tabell 7). 88 \% av de danske lærerne svarer at de bruker digital teknologi i 
Tabell 7 Prosentandel lærere i de nordiske landene som bruker digital teknologi for å fremme elevenes læring.

\begin{tabular}{lcccc}
\hline & Ikke i det hele tatt & I noen grad & I stor grad & I svært stor grad \\
\hline Danmark & 1 & 11 & 41 & 47 \\
Finland & 3 & 40 & 35 & 22 \\
Island & 9 & 28 & 31 & 32 \\
Norge & $\mathbf{1}$ & $\mathbf{3 3}$ & $\mathbf{4 6}$ & $\mathbf{2 0}$ \\
Sverige & 4 & 31 & 37 & 28 \\
\hline
\end{tabular}

stor eller svært stor grad, mens $66 \%$ av de norske svarer det samme. Det er lite forskjell på de andre nordiske landene, men finske lærere bruker teknologien minst for å fremme elevenes læring.

Vi ser i tillegg at det er noe forskjell når de nordiske lærerne er spurt om behov for faglig utvikling knyttet til bruk av digital teknologi i undervisningen (se tabell 8). Mens $70 \%$ av norske og islandske lærerne mener de har et visst behov eller stort behov, melder $43 \%$ av danske lærere om det samme og $59 \%$ av de svenske. Finske lærere ligger på $64 \%$ når de er stilt samme spørsmål.

Tabell 8 Prosentandel lærere i de nordiske landene som har behov for faglig utvikling knyttet til bruk av digital teknologi i undervisningen.

\begin{tabular}{lcccc}
\hline & Ikke noe behov & Litt behov & Et visst behov & Stort behov \\
\hline Danmark & 22 & 35 & 32 & 11 \\
Finland & 9 & 27 & 45 & 19 \\
Island & 9 & 21 & 49 & 21 \\
Norge & $\mathbf{1 0}$ & $\mathbf{2 0}$ & $\mathbf{4 8}$ & $\mathbf{2 2}$ \\
Sverige & 15 & 26 & 37 & 22 \\
\hline
\end{tabular}

Det er også interessant å se hvordan skoleledere svarer på spørsmål om hvorvidt manglende eller dårlig datautstyr til bruk i undervisningen forhindrer lærere fra å gi god undervisning. Over halvparten av skolelederne $(55 \%)$ sier at dette ikke har betydning i det hele tatt, men $35 \%$ svarer at dette til en viss grad har betydning for god undervisning på skolen og $10 \%$ svarer at dette har stor eller svert stor betydning. Skolelederne ble også bedt om å vurdere internettilkobling og hvorvidt den kunne være til hinder for god undervisning. $62 \%$ av skolelederne svarte at den $i k k e$ hadde betydning i det hele tatt, og $28 \%$ svarte til en viss grad. Generelt 
kan vi derfor si at ifølge skolelederne hindrer begrenset tilgang til utstyr og internettilkobling i liten grad god undervisning på skolen. Da kan vi konkludere med at det ikke er det tekniske utstyret og infrastruktur det står på, men at det heller er behovet for kompetanseheving lærere melder at de i svært stor grad mangler, og som i større grad hindrer pedagogisk bruk av digital teknologi i undervisning og læringsarbeid. Skoleleders prioriteringer og tilrettelegging slik at lærerne har anledning til å utvikle sin profesjonsfaglige digitale kompetanse med tanke på ressurser, tid og faglig fellesskap er derfor viktig å ta høyde for. Likeledes trenger den enkelte læreren å være villig til å ta i bruk utforskende og digitale metoder i faget sitt, og følge med på teknologien og de fagdidaktiske og pedagogiske mulighetene som åpner seg.

\section{Konklusjon}

Vi har nå sett på hovedfunnene i TALIS 2018 knyttet til bruk av digital teknologi og læreres PfDK. I lys av pandemien vi befinner oss i og de enorme endringene i undervisningspraksis hos lærere i løpet av de siste månedene, er det grunn til å tro at lyn-digitaliseringen har hatt betydning for læreres utvikling av PfDK. Resultatene i dette kapitlet kan derfor antas å allerede være noe utdaterte, eller i hvert fall beskrive lærernes bruk av digital teknologi i undervisningen ganske beskjedent. Med andre ord; den bratte læringskurven norske lærere har vært i gjennom i 2020 på grunn av skolestenging og hjemmeskole har høyst sannsynlig løftet den digitale kompetansen. I neste gjennomføring av TALIS i 2023 blir det derfor særlig interessant å sammenligne nye tall med det vi presenterer her.

Videre har vi sett at nettbasert undervisning og bruk av digitale læringsressurser kan åpne opp for mer fleksibilitet enn tradisjonelle læremidler. Muliggjøringen ligger i at elever og studenters bruk av læringsplattformer og læringsressurser (nettsider, digitale læreverk, samskrivingsplattformer o.1.) kan gi tilgang til ny kunnskap, men også bidra til økt fleksibilitet når det gjelder sted og rom, samspillet mellom individuelt arbeid og samarbeid, mellom større variasjon av undervisnings- og arbeidsmetoder og til og med mer elevsentrert læring (Frantzen \& Schofield, 2013). Det er likevel læreren og den profesjonsfaglige digitale kompetansen som står sentralt 
når det gjelder å bruke digital teknologi hensiktsmessig i klasserommet. Med hensiktsmessig menes at læreren trenger å inneha kompetanse som gjør det mulig å velge egnede digitale ressurser, men også til å velge bort når det ikke passer å bruke digital teknologi i læringsprosessen. Det er læreren som sitter på nøkkelen når det gjelder å fasilitere og koordinere læringsaktiviteter og styre læringstrykket, akkurat som i klasserom med begrenset tilgang til digital teknologi. I tillegg er det læreren som leder læringsarbeidet og bidrar til læringsfremmende aktiviteter, godt arbeidsmiljø og ro i timene.

Lærerrollen er og blir sentral når det gjelder bruk av digital teknologi, men det hviler også et stort ansvar på lærerutdanningen $\mathrm{i}$ å forberede fremtidige lærere på å jobbe best mulig i teknologitette klasserom og utvikle den kompetansen de trenger i fremtiden. Vi ser også at det blir stadig viktigere å vite hvordan vi kan ta hensyn både til eget og elevers personvern, å vite hvordan og hva elevene og lærere kan dele og gjenbruke fra nettet og ikke minst hvordan vi som digitale medborgere snakker med, om og til hverandre (Gudmundsdottir et al., 2020; Gudmundsdottir \& Hatlevik, 2020). På sosiale medier er det etablert en utmerket delingskultur hvor norske lærere deler tips om digitale læringsressurser og arbeidsmåter i nettbaserte omgivelser. Det er i stor grad takket være digitaliseringen av skolen som følge av covid-19-pandemien at lærere har fått erfaring med ulike løsninger som trolig har fremskyndet utviklingen av PfDK og bidratt til endringer i lærerrollen. Samtidig kan vi ikke se bort fra at behovet for kompetanseheving som lærerne har meldt fra om i TALIS 2018 fortsatt er reelt.

I internasjonal sammenheng ser vi også at norske skoler har god infrastruktur sammenlignet med andre land når det gjelder tilgang til digitale ressurser (Gudmundsdottir \& Throndsen, 2015; Hatlevik \& Throndsen, 2015). I tider når undervisning i stor grad foregår på nettet gir dette norske lærere noen fordeler, men den gode tilgangen til teknologien og digitale løsninger utgjør bare en del av det som trengs. Bruk av det tilgjengelige utstyret på en hensiktsmessig måte medfører at lærere ikke bare trenger grunnleggende digital kompetanse (Gudmundsdottir \& Hatlevik, 2018), men også motivasjon, kreativitet, nysjerrighet og endringsvilje til å ta i bruk nye metoder med digital teknologi (Brevik et al., 2018). Det er 
til slutt viktig å påpeke svakheten i spørsmålene i en slik internasjonal undersøkelse. Som i mange internasjonale kartlegginger bruker TALIS et standardisert spørreskjema som ikke gir rom for lokale varianter eller teorigrunnlag. Dette betyr at det ikke er mulig å for eksempel inkludere spørsmål direkte knyttet til rammeverk for grunnleggende ferdigheter eller PfDK. I tillegg er TALIS-spørsmålene om digital teknologi av et begrenset antall, noe som gir et svært avgrenset bilde av temaer knyttet til bruk av digital teknologi i norsk skole.

Teknologien er i stadig endring, og nye digitale verktøy, løsninger og ny programvare blir kontinuerlig utviklet. Lærere og lærerutdanningen trenger derfor å være endringsvillige og innstilt på å bistå fremtidige lærere med å prøve ut måter å løse nye utfordringer på. Dette kan videre forskning med fordel se på, for eksempel i lys av hvordan fagfornyelsen (LK20) krever økt utforskende og digital kompetanse i fagene og hvordan lærerutdanningen følger opp dette ved å utvikle endringsviljen og den fagdidaktiske kompetansen hos lærerstudentene.

\section{Referanser}

Albion, P. R., Tondeur, J., Forkosh-Baruch, A. \& Peeraer, J. (2015). Teachers' professional development for ICT integration: Towards a reciprocal relationship between research and practice. Education and Information Technologies, 2o(4), 655-673. https://doi.org/10.1007/s10639-015-9401-9

Atmacasoy, A. \& Aksu, M. (2018). Blended learning at pre-service teacher education in Turkey: A systematic review. Education and Information Technologies, 23, 23992422. https://doi.org/10.1007/s10639-018-9723-5

Blikstad-Balas, M. \& Klette, K. (2020). Still a long way to go. Nordic Journal of Digital Literacy, 15(o1), 55-68. https://doi.org/10.18261/issn.1891-943X-2020-01-05

Brevik, L. M. \& Davies, C. (2016). The potential of digital tools for enabling the observation of comprehension in the classroom. Nordic Journal of Digital Literacy, 11(2), 101-117. https://doi.org/10.18261/issn.1891-943X-2016-02-02

Brevik, L. M., Gudmundsdottir, G. B., Lund, A. \& Strømme, T. A. (2019). Transformative agency in teacher education: Fostering professional digital competence. Teaching and Teacher Education, 86(2019). https://doi.org/10.1016/j. tate.2019.07.005

Chin, C. K., Munip, H., Miyadera, R., Thoe, N. K., Ch'ng, Y. S. \& Promsing, N. (2018). Promoting education for sustainable development in teacher education 
integrating blended learning and digital tools: An evaluation with exemplary cases. Eurasia Journal of Mathematics, Science and Technology Education, 15(1), 1-17. https://doi.org/10.29333/ejmste/99513

Crawford, R. \& Jenkins, L. E. (2018). Making pedagogy tangible: Developing skills and knowledge using a team teaching and blended learning approach. Australian Journal of Teacher Education, 43(1), 127-142. https://doi.org/10.14221/ ajte.2018v43n1.8

Daniel, S. J. (2020). Education and the COVID-19 pandemic. Prospects. https://doiorg.ezproxy.uio.no/10.1007/s11125-020-09464-3

Daus, S., Aamodt, P. O., \& Tømte, C. (2019). Profesjonsfaglig digital kompetanse i loererutdanningene. Undersøkelse av tilstand, holdninger og ferdigheter ved fem grunnskoleloererutdanninger (13). f. o. u. N. Nordisk institutt for studier av innovasjon. http://hdl.handle.net/11250/2602702

Dicte. (2019). Pedagogical, ethical, attitudinal and technical dimensions of digital competence in teacher education (PEAT). Developing ICT in Teacher Education Erasmus+ project. https://dicte.oslomet.no/dicte/

Egeberg, G., Gudmundsdottir, G. B., Hatlevik, O. E., Ottestad, G., Skaug, J. H. \& Tømte, K. (2012). Monitor 2011. Skolens digitale tilstand. Udir. https://www.udir. no/tall-og-forskning/finn-forskning/rapporter/monitor-2011---skolens-digitaletilstand/

Ferdig, R. E., Baumgartner, E., Hartshorne, R., Kaplan-Rakowski, R. \& Mouza, C. (2020). Teaching, technology, and teacher education during the COVID-19 pandemic: Stories from the field. Association for the Advancement of Computing in Ecuation. https://www.learntechlib.org/p/216903/

Fjørtoft, S. O., Thun, S. \& Buvik, M. P. (2019). Monitor 2019. En deskriptiv kartlegging av digital tilstand $i$ norske skoler og barnehager (SINTEF rapport 2019:00877). https://www.udir.no/contentassets/92b2822fa64e4759b4372d67bcc8bc61/monitor2019-sluttrapport_sintef.pdf

Frantzen, V. \& Schofield, D. (2013). Artefakter i nye læringsmiljø. I I. R. Karlsdottir \& I. H. Lysø (Red.), Loring - Utvikling - Loeringsmiljø (s. 327-346). Akademika.

Gil-Flores, J., Rodríguez-Santero, J. \& Torres-Gordillo, J.-J. (2017). Factors that explain the use of ICT in secondary-education classrooms: The role of teacher characteristics and school infrastructure. Computers in Human Behavior, 68, 441-449. https://doi.org/10.1016/j.chb.2016.11.057

Gudmundsdottir, G. B., Gassó, H. H., Rubio, J. C. C. \& Hatlevik, O. E. (2020). Student teachers' responsible use of ICT: Examining two samples in Spain and Norway. Computers \& Education, 152, 103877. https://doi.org/10.1016/j. compedu.2020.103877 
Gudmundsdottir, G. B. \& Hathaway, D. M. (2020). «We always make it work»: Teachers' agency in the time of crisis. Journal of Information Technology and Teacher Education, 28(2), 239-250. https://www.learntechlib.org/primary/p/216242/

Gudmundsdottir, G. B. \& Hatlevik, O. E. (2018). Newly qualified teachers' professional digital competence: Implications for teacher education. European Journal of Teacher Education, 41(2), 214-231. https://doi.org/10.1080/02619768.20 17.1416085

Gudmundsdottir, G. B. \& Hatlevik, O. E. (2020). «I just Google it». Developing professional digital competence and preparing student teachers to exercise responsible ICT use. Nordic Journal of Comparative and International Education, 4(3), 39-55. http://doi.org/10.7577/njcie.3752

Gudmundsdottir, G. B., Loftsgarden, M. \& Ottestad, G. (2014). Profesjonsfaglig digital kompetanse og erfaringer med IKT i loererutdanningen. Senter for IKT i utdanningen.

Gudmundsdottir, G. B. \& Ottestad, G. (2016). Veien mot profesjonsfaglig digital kompetanse i lærerutdanningen. I R. Krumsvik (Red.), Digital loring i skule og loerarutdanning (2. utg., s. 70-82). Universitetsforlaget.

Gudmundsdottir, G. B. \& Throndsen, I. (2015). IKT i skolen. I O. E. Hatlevik \& I. Throndsen (Red.), Loering av IKT. Elevenes digitale ferdigheter og bruk av IKT i ICILS 2013 (s. 125-145). Universitetsforlaget. https://doi. org/10.18261/9788215025902-2015-08

Gudmundsdottir, G. B. \& Vasbø, K. B. (2017). Toward improved professional digital competence: The use of blended learning in teacher education in Norway. Paper presentert på SITE - Society for Information Technology and Teacher Education, Austin, TX, USA.

Haapasaari, A., Engeström, Y. \& Kerosuo, H. (2016). The emergence of learners' transformative agency in a Change Laboratory intervention. Journal of Education and Work, 29(2), 232-262. https://doi.org/10.1080/13639080.2014.900168

Hatlevik, O. E. (2017). Examining the relationship between teachers' self-efficacy, their digital competence, strategies to evaluate information, and use of ICT at school. Scandinavian Journal of Educational Research, 61(5), 555-567. https://doi. org/10.1080/o0313831.2016.1172501

Hatlevik, O. E., Egeberg, G., Gudmundsdottir, G. B., Loftsgarden, M. \& Loi, M. (2013). Monitor skole 2013. Om digital kompetanse og erfaringer med bruk av IKT $i$ skolen. Senter for IKT i utdanningen. https://www.udir.no/globalassets/monitor_ skole_2013_4des.pdf

Hatlevik, O. E. \& Gudmundsdottir, G. B. (2013). An emerging digital divide in urban school children's information literacy: Challenging equity in the Norwegian school system. First Monday, 18(4). https://doi.org/10.5210/fm.v18i4.4232 
Hatlevik, O. E. \& Throndsen, I. (Red.). (2015). Loring av IKT. Elevenes digitale ferdigheter og bruk av IKT i ICILS 2013. Universitetsforlaget. https://doi. org/10.18261/9788215025902-2015

Hjukse, H., Aagaard, T., Bueie, A. A., Moser, T. \& Vika, K. S. (2020). Digitalisering i grunnskolelærerutdanningen: Om faglige forskjeller i arbeidet med profesjonsfaglig digital kompetanse. Acta Didactica Norden, 14(1), 1-27. http:// dx.doi.org/10.5617/adno.8023

Instefjord, E. \& Munthe, E. (2016). Preparing pre-service teachers to integrate technology: An analysis of the emphasis on digital competence in teacher education curricula. European Journal of Teacher Education, 39(1), 77-93. https:// doi.org/10.1080/02619768.2015.1100602

Instefjord, E. J. \& Munthe, E. (2017). Educating digitally competent teachers: A study of integration of professional digital competence in teacher education. Teaching and Teacher Education, 67, 37-45. https://doi.org/10.1016/j.tate.2017.05.016

Kelentrić, M., Helland, K. \& Arstorp, A.-T. (2017). Rammeverk for loererens profesjonsfaglige digitale kompetanse (PfDK) [Artikkel]. Udir. https://www.udir. no/kvalitet-og-kompetanse/profesjonsfaglig-digital-kompetanse/rammeverklarerens-profesjonsfaglige-digitale-komp/

Klausen, S. W. (2020). Fra kritt til programmering. En kritisk diskursanalyse av begrepet digitale ferdigheter i norsk utdanningspolitikk og i norsk videregående opplaering (Doktorgradsavhandling, Høgskolen i Innlandet). Brage INN. http:// hdl.handle.net/11250/2643315

Koehler, M. J. \& Mishra, P. (2005). What happens when teachers design educational technology? The development of Technological Pedagogical Content Knowledge. Journal of Educational Computing Research, 32(2), 131-152. https://doi. org/10.2190/oEW7-o1WB-BKHL-QDYV

Krumsvik, R. J. (2014). Teacher educators' digital competence. Scandinavian Journal of Educational Research, 58(3), 269-28o. https://doi.org/10.1080/00313831.2012.72 6273

Livingstone, S. (2012). Critical reflections on the benefits of ICT in education. Oxford Review of Education, 38(1), 9-24. https://doi.org/10.1080/03054985.2011.577938

Ludvigsen, S. \& Dæhlen, M. (2020, 15. juli). Den doble digitaliseringen: Fag og undervisning i endring [Debattinnlegg]. Khrono. https://khrono.no/den-dobledigitaliseringenfag-og-undervisning-i-endring/501516

Lund, A., Furberg, A., Bakken, J. \& Engelien, K. L. (2014). What does professional digital competence mean in teacher education? Nordic Journal of Digital Literacy, 9(4), 280-298. https://www.idunn.no/dk/2014/o4/what_does_professional_ digital_competence_mean_inteacher_e 
Lund, A., Furberg, A. \& Gudmundsdottir, G. B. (2019). Expanding and embedding digital literacies: Transformative agency in education. Media and Communication, 7(2), 47-58. http://dx.doi.org/10.17645/mac.v7i2.188o

Lund, A. \& Vestøl, J. M. (2020). An analytical unit of transformative agency:

Dynamics and dialectics. Learning, Culture and Social Interaction, 25. https://doi. org/10.1016/j.lcsi.2020.10039o

Medietilsynet. (2018). Barn og medier-undersøkelsen 2018. 9-18-åringer om medievaner og opplevelser. https://medietilsynet.no/globalassets/publikasjoner/ barn-og-medier-undersokelser/2018-barn-og-medier

Medietilsynet. (2020). Barn og medier-undersøkelsen 2020. https://medietilsynet.no/ barn-og-medier/barn-og-medier-undersokelsen/

Nagel, I. (2021). What should teacher educators know and be able to do? Digital competence in teacher education curricula. Høgskolen i Østfold, Avdeling for lærerutdanning [manuskript til fagfellevurdering].

OECD. (2010). TALIS 2008 Technical Report. TALIS, OECD Publishing. https://doi. org/10.1787/9789264079861-en

OECD. (2014). TALIS 2013 Results: An international perspective on teaching and learning. TALIS, OECD Publishing. https://doi.org/10.1787/23129638

Punie, Y. \& Ala-Mutka, K. (2007). Future learning spaces: New ways of learning and new digital skills to learn. Nordic Journal of Digital Literacy, 2(4), 210-225. https:// www.idunn.no/dk/2007/o4/future_learning_spaces_new_ways_of_learning and_new_digital_skills_to_learn

Rienties, B., Giesbers, B., Lygo-Baker, S., Ma, H. W. S. \& Rees, R. (2016). Why some teachers easily learn to use a new virtual learning environment: A technology acceptance perspective. Interactive Learning Environments, 24(3), 539-552. https:// doi.org/10.1080/10494820.2014.881394

Røkenes, F. M. \& Krumsvik, R. J. (2014). Development of student digital competence in teacher education - A literature review. Nordic Journal of Digital Literacy, 9(4), 250-28o.https://www.idunn.no/dk/2014/o4/development_of_student_teachers_ digital_competence_in_teac

Tondeur, J., Aesaert, K., Prestridge, S. \& Consuegra, E. (2018). A multilevel analysis of what matters in the training of pre-service teacher's ICT competencies. Computers \& Education, 122, 32-42. https://doi.org/10.1016/j.compedu.2018.03.002

Tondeur, J., Scherer, R., Siddiq, F. \& Baran, E. (2017). A comprehensive investigation of TPACK within pre-service teachers' ICT profiles: Mind the gap! Australasian Journal of educational technology, 33(3). https://doi.org/10.14742/ajet.3504

Tømte, C., Kårstein, A. \& Olsen, D. S. (2013). IKT i leererutdanningen. På vei mot profesjonsfaglig digital kompetanse? (NIFU-rapport 2013:20). https://www.nifu.no/ publications/1027114/ 
Uluyol, Ç. \& Şahin, S. (2016). Elementary school teachers' ICT use in the classroom and their motivators for using ICT. British Journal of Educational Technology, 47(1), 65-75. https://doi.org/10.1111/bjet.12220

Utdanningsdirektoratet. (2012). Rammeverk for grunnleggende ferdigheter. Til bruk for loereplangrupper oppnevnt av Utdanningsdirektoratet. https://www.udir.no/ globalassets/upload/larerplaner/lareplangrupper/rammeverk_grf_2012.pdf

Utdanningsdirektoratet (2017). Rammeverk for grunnleggende ferdigheter. Til bruk for læreplangrupper oppnevnt av Utdanningsdirektoratet. https://www.udir.no/ laring-og-trivsel/rammeverk/rammeverk-for-grunnleggende-ferdigheter/

Utdanningsdirektoratet. (2020a). Loreplan i naturfag (NATo1-04). Grunnleggende ferdigheter. https://www.udir.no/lk2o/nato1-04/om-faget/grunnleggendeferdigheter

Utdanningsdirektoratet. (2020b). Loereplan i norsk (NORo1-06). Grunnleggende ferdigheter. https://www.udir.no/lk2o/noro1-06/om-faget/grunnleggendeferdigheter

Utdanningsdirektoratet. (2020c). Loreplan i samfunnsfag (SAFo1-04). Grunnleggende ferdigheter. https://www.udir.no/lk2o/safo1-04/om-faget/grunnleggendeferdigheter

Utdanningsdirektoratet. (2020d). Loreplanverket. https://www.udir.no/laring-ogtrivsel/lareplanverket/

Virkkunen, J. (2006). Dilemmas in building shared transformative agency. Activités, 3(3-1). https://doi.org/10.400o/activites.1850

Voet, M. \& De Wever, B. (2017). Towards a differentiated and domain-specific view of educational technologies: An exploratory study of history teachers' technology use. British Journal of Educational Technology, 48(6), 1402-1413. https://doi. org/10.1111/bjet.12493

Aasen, P., Møller, J., Rye, E., Ottesen, E., Prøitz, T. S. \& Hertzberg, F. (2012). Kunnskapsløftet som styringsreform et løft eller et løfte? Forvaltningsnivåenes og institusjonenes rolle i implementeringen av reformen (NIFU-rapport 2012:20). http://hdl.handle.net/11250/280885 


\title{
Profesjonelle fellesskap på ungdomstrinnet som del av skolens utvikling
}

\author{
Tone Cecilie Carlsten
}

Nordisk institutt for studier av innovasjon, forskning og utdanning (NIFU)

\section{Inger Throndsen \& Julius K. Björnsson}

Institutt for skoleforskning og lærerutdanning, Universitetet i Oslo

\begin{abstract}
Professional communities at the lower secondary level as part of the school's development

This chapter invites to a discussion of how TALIS 2018 data about professional communities relates to recent policy development aimed at school development. Teacher collaboration is considered a central resource in the individual school's organization, and exchange of experience with colleagues is often highlighted when teachers are asked about their most important source of learning and development. Policy development in Norway has aimed at strengthening professional collaboration for quality development of schools, especially at the lower secondary level. The chapter highlights some results from TALIS 2018 that show how teachers at the lower secondary level collaborate and how school leaders provide feedback and assessments to support and facilitate the teachers' further professional development by asking what the characteristics of collaboration at the lower secondary level are; and what kind of measures school leaders are implementing to support teachers who need follow-up. Answers to these questions are compared to Norwegian findings from TALIS 2008 and TALIS 2013.
\end{abstract}

Keywords: professional communities, school development, teacher collaboration, school leadership

Sitering av denne artikkelen: Carlsten, T. C., Throndsen, I. \& Björnsson, J. K. (2021). Profesjonelle fellesskap på ungdomstrinnet som del av skolens utvikling. I J. K. Björnsson (Red.), Hva kan vi loere av TALIS 2018? Gode relasjoner som grunnlag for loering (Kap. 5, s. 87-106). Cappelen Damm Akademisk. https://doi. org/10.23865/noasp.123.ch5

Lisens: CC BY-NC-ND 4.0. 


\section{Introduksjon}

Som nevnt i kapittel 1 er ett av hovedfunnene i TALIS 2018 at Norge har et ungdomstrinn preget av en sterk samarbeidskultur. Undersøkelsen viser også at det er en god felles ansvarsforståelse for skolens oppgaver internt i kollegiet (Carlsten et al., 2021). Disse funnene ligger innenfor det vi i figur 1 i kapittel 1 viste til som kollegasamarbeid (område 2) og ansvar og autonomi (område 3). Samarbeidskultur er det vi kan kalle en del av de performative sider av et profesjonsfellesskap, mens ansvarskultur også kan handle om organisatoriske aspekter ved lærerprofesjonalitet (Hermansen et al., 2018). Et profesjonsfellesskap kan i denne sammenheng defineres som et fellesskap av lærere og skoleledere som på kritisk og konstruktivt vis klarer å relatere sitt profesjonelle skjønn til erfaringsbasert kunnskap, forskning, skolepolitikk og samfunnets bevegelser, jf. skolens samfunnsmandat (Dahl et al., 2016).

Lærersamarbeid blir vurdert som en svært sentral ressurs i den enkelte skoles organisasjon ved at den enkelte lærers individuelle pedagogiske ressurser brukes og utnyttes konstruktivt gjennom lærersamarbeid (Bjørnsrud, 2009; Møller, 2011). Når lærere blir spurt om deres viktigste kilde til læring og utvikling, trekkes erfaringsutveksling med kolleger ofte frem (Jensen og Cooper, 20015. Slik kollektiv kunnskapsutvikling har de senere årene fått økt oppmerksomhet og har å gjøre med utvikling av profesjonelle læringsfellesskap i og på tvers av skoler. Utviklingen av profesjonelle fellesskap på ungdomstrinnet har vært et tydelig mål i de senere års policy for skoleutvikling. I den sammenheng har funn fra TALIS tidligere bidratt til å fremheve at tilbakemeldinger fra skoleleder til lærere og lærere imellom på deres undervisning er et område som har hatt behov for å styrkes i praksis (Caspersen et al., 2014; Vibe et al., 2009).

Som hovedfunnene fra TALIS 2018 viser i kapittel 1, har norske ungdomsskolelærere på et slikt overordnet nivå et godt grunnlag for å inngå i profesjonsfellesskap som kan styrke elevenes læringsutbytte. I dette kapittelet skal vi se nærmere på spørsmål i TALIS 2018 som kan relateres til de senere års policyutvikling om profesjonelle fellesskap. Policyutviklingen i Norge har hatt som mål å angi veier mot et styrket profesjonelt samarbeid for kvalitetsutvikling spesielt på ungdomstrinnet. Kapittelet trekker frem noen resultater som viser hvordan lærere på ungdomstrinnet samarbeider 
og hvordan skoleledere gir tilbakemeldinger og vurderinger for å støtte opp under og legge til rette for lærernes videre profesjonsutvikling. På bakgrunn av data fra TALIS 2018 ønsker vi å besvare følgende spørsmål:

- Hva kjennetegner samarbeidsformer på ungdomstrinnet?

- Hvilken betydning har skolelederes tilbakemeldinger på lærernes praksis?

- Hva slags tiltak iverksetter skoleledere for å støtte lærere som trenger oppfølging?

- Hva kan innsikt på disse områdene bidra med av kunnskap om profesjonsfellesskap i Norge i dag?

Svar på disse spørsmålene vil også bli sett i relasjon til funn fra TALIS 2008 og TALIS 2013. Tidligere TALIS-undersøkelser viste at skoleledere hadde svake rutiner for å vurdere lærernes arbeid og for å gi dem god oppfølging for å styrke profesjonell utvikling (Caspersen et al., 2014; Vibe et al., 2009). Det har imidlertid vært store endringer i lærerutdanningen og etter- og videreutdanningsmuligheter både for lærere og skoleledere de senere årene.

Kapittelet starter med en kort gjennomgang av formålstjenlige samarbeids- og oppfølgingsformer på ungdomstrinnet, slik vi finner det i de senere års policysammenheng i Norge. Deretter beskriver vi hvordan tema og spørsmål knyttet til profesjonelle fellesskap i skolen utvikles i TALIS-sammenheng, før vi viser sammenhenger mellom spørsmål og svar for ulike former for to utvalgte tema: verdien av ulike former for lærersamarbeid og sammenhenger mellom tilbakemeldingskultur og profesjonell utvikling. Vi avslutter kapittelet med å vise til hvordan TALIS-undersøkelsen i seg selv kan diskuteres som et ledd i arbeidet med å reflektere over sammenhenger mellom norsk policyutvikling og egen profesjonell praksis for skoleledere, lærere og lærerstudenter.

\section{Profesjonsfellesskap og skoleutvikling i policysammenheng}

Kunnskapsdepartementets strategi for ungdomstrinnet, Motivasjon og mestring for bedre loering, pekte på noen hovedutfordringer for en mangfoldig og inkluderende fellesskole i Norge (Kunnskapsdepartementet, 
2012). Strategien bygget på signaler fra stortingsmeldingen Motivasjon Mestring - Muligheter, der det ble fremhevet at statistikk og forskning viste at elevenes motivasjon for læring var lavest på ungdomstrinnet (Meld. St. 22 (2010-2011)). Strategien førte blant annet til satsingen Ungdomstrinn i utvikling 2012-2017. Der var skolebasert kompetanseutvikling, nettbaserte ressurser og nettverksbasert erfaringsutveksling og profesjonsfellesskap tre sentrale virkemidler som skulle bidra til å videreutvikle skolen som en lærende organisasjon. Disse understreket at elevenes læring henger sammen med kollektiv kunnskapsbygging og en felles ansvarskultur både innad på skoler, regionalt i nettverk og som nasjonalt satsingsområde (Lødding et al., 2018).

Prinsippene om profesjonelt samarbeid for kvalitetsutvikling har vært gjennomgående i de senere års policydokumenter for lærere og for skolen. En av ambisjonene for Kunnskapsløftet var at skolene i større grad skulle utvikle en kultur for læring, jf. stortingsmeldingen Kultur for loering (St.meld. nr. 30 (2003-2004)). Målet om å styrke læreres profesjonsfellesskap finner vi også igjen i dokumenter som Loererløftet: På lag for kunnskapsskolen (Kunnskapsdepartementet, 2014) og Kompetanse for kvalitet: Strategi for etter- og videreutdanning 2012-2015 (Kunnskapsdepartementet, 2015). Målet om å forbedre skolenes evne og vilje til å lære og utvikle seg har vært gjennomgående også i senere meldinger på vei mot fagfornyelsen, for eksempel i stortingsmeldingene Fag - Fordypning - Forståelse - En fornyelse av Kunnskapsløftet (Meld. St. 28 (2015-2016)) og Loerelyst - tidlig innsats og kvalitet $i$ skolen (Meld. St. 21 (2016-2017)). I Meld. St. 28 (s. 68) defineres blant annet profesjonsfellesskap på følgende måte:

En profesjon er også et fellesskap bundet sammen av en faglig tradisjon og felles normer. Lærerne på den enkelte skole utgjør et profesjonsfellesskap. De er ikke bare ansatt av samme arbeidsgiver, men utgjør et faglig fellesskap som selv bidrar til å lage felles standarder og utvikle profesjonelle normer som skal ivareta skolens brede mandat. I tillegg inngår lærerne også i ulike fagfellesskap, som for eksempel gjennom å være norsklærere, matematikklærere, kroppsøvingslærere osv., som gir en felles identitet på tvers av skoler.

Evalueringer av disse reformtiltakene og satsingene har imidlertid pekt på at målene ikke har blitt innfridd i det omfang som lå i intensjonene, og 
at samarbeid av denne typen har variert mellom skoler (Dahl et al., 2016; Lødding et al., 2018).

Den overordnede delen av fagfornyelsen, det vil si de nye læreplanene for grunnopplæringen som ble implementert høsten 2020, viderefører og utdyper verdigrunnlaget og prinsippene for profesjonsfellesskap og skoleutvikling. I del 3.5 av den overordnede delen som omhandler prinsipper for skolens praksis, påpekes det at velfungerende profesjonsfellesskap er avgjørende for at lærere ikke bare skal føle et felles ansvar for elevenes læring, men også for å kunne utvikle sin egen kompetanse (Kunnskapsdepartementet, 2017). Det fremheves også at det profesjonelle samarbeidet ved skolene forutsetter god ledelse, slik vi også kjenner det fra norsk forskning på skoleledelse (Møller \& Ottesen, 2011). Videre vises det til at god skoleutvikling krever rom for å stille spørsmål og lete etter svar der alle ansatte deltar aktivt i det profesjonelle læringsfellesskapet for å videreutvikle det innovative miljøet i skolen (Kunnskapsdepartementet, 2017).

Fagfornyelsen legger til grunn læreres felles ansvar for elevenes læring og egen kompetanseutvikling, lederes profesjonsstøttende tilbakemeldinger og vurderinger samt åpenhet for innovasjon. Disse prinsippene er også indikatorer på profesjonsfellesskap som inngår i TALIS 2018. I kapittel 3 i denne boken har vi sett at en distribuert ledelse for et innovativt miljø på skolen gir positive effekter. Her ble det presentert funn som viser at et innovativt miljø igjen fremmer de læringseffektene som policyfeltet etterspør og som forskningsmiljøer fremhever som gode, men at effektene er sterkere på skolenivå enn på lærernivå (Nilsen et al., 2021). I det følgende vil vi derfor ikke fokusere ytterligere på åpenhet for innovasjon, men heller se på noen funn som viser hva TALIS-undersøkelsen sier om de to førstnevnte indikatorene på profesjonsfellesskap: kollegasamarbeid lærere imellom samt rektorenes vurdering av lærernes arbeid og påfølgende oppfølging.

\section{Lærersamarbeid, tilbakemeldinger og oppfølging i TALIS 2018}

Lærersamarbeid og skoleledernes tilbakemeldinger og oppfølging av lærerne anses som viktige faktorer med tanke på å støtte og utvikle 
skolens profesjonsfellesskap. I TALIS-undersøkelsen er ulike aspekter ved skoleledelse og læreres profesjonspraksis sentrale tema.

Lærersamarbeid blir vurdert som en svært sentral ressurs i den enkelte skoles organisasjon ved at den enkelte lærers individuelle pedagogiske ressurser brukes og utnyttes konstruktivt gjennom lærersamarbeid (Bjørnsrud, 2009; Møller, 2011). Når lærere blir spurt om deres viktigste kilde til læring og utvikling, trekkes erfaringsutveksling med kolleger ofte frem (Jensen, 2008). Slik kollektiv kunnskapsutvikling har de senere årene fått økt oppmerksomhet og har å gjøre med utvikling av profesjonelle læringsfellesskap i og på tvers av skoler (Kvam, 2014, 2018).

Internasjonal forskning viser at lærersamarbeid kan ha betydning for ulike aspekter ved læreres arbeid (Fuglestad et al., 2017; Goddard et al., 2007; Timperley et al., 2007). Samarbeid kan blant annet bidra til å utvikle lærernes kunnskap om ulike sider ved yrkesutøvelsen, noe som kan føre til kritisk refleksjon over egen praksis. Dette betyr at lærersamarbeid i neste omgang kan ha positiv effekt på lærernes undervisning og elevenes læring. På denne måten knyttes læringsfellesskapene til at elevenes læring forbedres ved at lærernes læring øker (Beninghof, 2012; Vescio et al., 2008). Det har også vist seg at lærere som arbeider ved skoler preget av klima for samarbeid viser større engasjement for jobben og opplever en sterkere fellesskapsfølelse (Hargreaves, 1994).

Samarbeid kan ha ulike former, fra uformelle og uforpliktende aktiviteter til mer formelt og forpliktende samarbeid. I TALIS-undersøkelsen skilles det mellom to former for lærersamarbeid. Mens noen samarbeidsformer kan knyttes direkte til undervisningskonteksten, er annet samarbeid av mer praktisk og koordinerende art. For å få kunnskap om hvilke samarbeidsformer som preger ungdomstrinnet samt hvor hyppig samarbeid forekommer, besvarte lærerne følgende spørsmål: «Omtrent hvor ofte gjør du følgende på denne skolen?»

Svaralternativene var «aldri», «en gang $i$ året eller sjeldnere», «2-4 ganger i året», «5-10 ganger i året», «1-3 ganger i måneden» og «En gang i uka eller oftere». Resultatene presenteres i tabell 1. I tabellen er noen av svarkategoriene slått samme. «En gang i året eller sjeldnere», «2-4 ganger $\mathrm{i}$ året» og «5-10 ganger i året» er slått sammen til «Sjeldnere enn en gang 
i måneden», mens «1-3 ganger i måneden» og «En gang i uka eller oftere» er kategorisert som «Minst en gang i måneden».

I alle tre rundene av TALIS har man operert med to indekser for lærersamarbeid basert på utsagn til dette spørsmålet om lærersamarbeid: Koordinering og profesjonelt samarbeid. I rapporteringen fra TALIS 2018 har vi omtalt dette som praktisk/koordinerende samarbeid og som samarbeid knyttet til undervisningen. I kortrapporten TALIS 2018 - flere funn fra ungdomstrinnet (Carlsten et al., 2020) slo vi sammen noen av kategoriene, men tabell 1 viser hvordan de ulike utsagnene over fordeles på de to indeksene.

Tabell 1 Lærernes svar på hvor ofte de deltar i ulike samarbeidsaktiviteter (Carlsten et al., 2020).

\begin{tabular}{|c|c|c|c|c|}
\hline Samarbeidsform & Aktivitet & Aldri & $\begin{array}{l}\text { Sjeldnere } \\
\text { enn én gang } \\
\text { i måneden }\end{array}$ & $\begin{array}{l}\text { Minst én } \\
\text { gang i } \\
\text { måneden }\end{array}$ \\
\hline \multirow{4}{*}{$\begin{array}{l}\text { Samarbeid knyttet } \\
\text { til undervisningen }\end{array}$} & Underviser i team i samme klasse & 36 & 27 & 37 \\
\hline & $\begin{array}{l}\text { Observerer andre læreres } \\
\text { undervisning og gir tilbakemelding }\end{array}$ & 37 & 52 & 11 \\
\hline & $\begin{array}{l}\text { Deltar i fellesaktiviteter på tvers } \\
\text { av klasser og aldersgrupper (f.eks. } \\
\text { prosjektarbeid) }\end{array}$ & 19 & 72 & 9 \\
\hline & $\begin{array}{l}\text { Deltar i faglig kompetanseutvikling } \\
\text { med kolleger }\end{array}$ & 5 & 52 & 44 \\
\hline \multirow{4}{*}{$\begin{array}{l}\text { Praktisk/ } \\
\text { koordinerende } \\
\text { samarbeid }\end{array}$} & $\begin{array}{l}\text { Utveksler undervisningsmateriell } \\
\text { med kolleger }\end{array}$ & 2 & 29 & 70 \\
\hline & $\begin{array}{l}\text { Diskuterer utviklingen til bestemte } \\
\text { elever }\end{array}$ & 0 & 11 & 89 \\
\hline & $\begin{array}{l}\text { Samarbeider med andre lærere ved } \\
\text { skolen for å sikre felles standarder for } \\
\text { vurdering av elevenes utvikling }\end{array}$ & 3 & 34 & 63 \\
\hline & Deltar på teammøter & 2 & 6 & 92 \\
\hline
\end{tabular}

Som det går frem av tabellen, er samarbeidet på ungdomstrinnet i første rekke preget av praktiske og koordinerende aktiviteter, som for eksempel deltakelse på teammøter, utveksling av undervisningsmateriell og diskusjon om utviklingen til bestemte elever. Samarbeid direkte knyttet til undervisningskonteksten forekommer langt sjeldnere. For eksempel svarer nesten hver fjerde lærer at de aldri observerer andre læreres undervisning og gir tilbakemelding. Slikt samarbeid anses som svært 
godt egnet til å utveksle kunnskap som kan bidra til å forbedre undervisningen. Videre svarer omtrent hver tredje lærer at de aldri underviser i team i samme klasse. På den andre siden svarer nærmere halvparten av lærerne at de ofte deltar i faglig kompetanseutvikling sammen med kolleger. Internasjonalt skiller Norge seg ut på dette området ved å ha den høyeste andelen lærere som deltar i faglig kompetanseutvikling sammen med kolleger. Dette må ses i sammenheng med den nasjonale strategien for etter- og videreutdanning (Carlsten et al., 2020).

Samme spørsmål med samme svaralternativ og samme utsagn ble stilt i TALIS 2013. Unntaket var det siste nasjonale tilleggsutsagnet i listen over, som var en direkte oppfølging av hovedfunn i TALIS 2013, jf. diskusjonen i kapittel 1 (Carlsten et al., 2021).

Et lignende spørsmål ble også stilt i TALIS 2008, men både utsagn og svaralternativ har blitt noe endret siden den gang og kan derfor ikke direkte sammenlignes.

Videre fikk både lærere og rektorer spørsmål relatert til vurderinger av og tilbakemeldinger til lærere om hvordan de utfører jobben sin. Slike tilbakemeldinger anses som et viktig ledd i læreres kompetanseutvikling, som igjen er ment å kunne forbedre undervisningen. Her ligger det altså et analytisk potensial til å finne sammenhenger mellom organisatoriske og performative sider av profesjonsfellesskap.

Et av hovedfunnene fra TALIS 2013 var at norsk skole var preget av en svak tilbakemeldings- og oppfølgingskultur. Formålet med tilbakemeldinger er å utvikle lærerens profesjonskunnskap slik at det fører til justeringer eller tilpasninger i undervisningen. Det vesentlige med tilbakemeldingene i denne sammenheng er at de gir økt kunnskap om undervisning og læring samt kan bidra til økt refleksjon over egen praksis, som igjen kan gi bedre undervisning. Spørsmål om vurdering og tilbakemelding har alltid hatt en sentral plass i TALIS-undersøkelsene. Siden TALIS 2008-rapporteringen har funn om dette temaet inngått som et hovedanliggende i norsk skolepolitikk. Resultater har vist at vurderinger lærere mottar i liten grad har inneholdt konkrete forslag til forbedringer, og de har heller ikke ført til nevneverdige konsekvenser som kan forbedre undervisning for den enkelte eller bidra til kollektiv kompetanseutvikling (Caspersen et al., 2014; Vibe et al., 2009). 
TALIS 2018 viser at $69 \%$ av de norske ungdomsskolelærerne i løpet av de siste 12 månedene har mottatt tilbakemeldinger som har hatt positiv betydning for undervisningspraksisen deres. For å kartlegge dette, besvarte lærerne følgende spørsmål: «Tenk på tilbakemeldingene som $d u$ har fätt $i$ løpet av de siste 12 månedene. Har de ført til en positiv endring $i$ noen av følgende sider ved jobben din som loerer?» Tabell 2 viser andelen lærere som svarer «ja»på de ulike aspektene ved lærerjobben.

Tabell 2 Prosentandelen lærere som svarer «ja» på spørsmålet om tilbakemeldinger har hatt positiv effekt på ulike sider ved jobben.

\begin{tabular}{lc}
\hline Positiv endring etter tilbakemelding & Andel som svarer «ja» \\
\hline Kunnskap om og forståelse av mitt/mine fagområde( $r)$ & 44 \\
$\begin{array}{l}\text { Kunnskap om og forståelse av didaktikk innen mitt/mine } \\
\text { fagområde( } r)\end{array}$ & 48 \\
Bruk av prøver for å forbedre elevenes læring & 34 \\
Min klasseledelse & 49 \\
Mine metoder i undervisning av elever med særlige opplæringsbehov & 34 \\
Mine metoder for å undervise i et flerkulturelt eller flerspråklig miljø & 12 \\
\hline
\end{tabular}

Vi ser her at det er under halvparten av lærerne som mener tilbakemeldingene har betydning for forbedring av arbeidet deres. Det er positivt at så mange anser tilbakemeldingene de får som nyttige, men det kan se ut som det fortsatt er arbeid som gjenstår for at tilbakemeldinger kan få den ønskede effekten på utvikling av profesjonelt arbeid og dermed være en rutine i skoleutvikling.

Det er flere såkalte «batterier», dvs. samlinger av utsagn som gir mening som svar på et spørsmål når de ses i sammenheng, som berører temaet tilbakemelding og vurdering i TALIS-undersøkelsen. Tilsvarende spørsmålssamlinger har også inngått i de to tidligere TALIS-rundene i 2008 og 2013, med begrunnelsen at det er en vesentlig forutsetning for kvalitetsutvikling at det gis tilbakemeldinger på utført arbeid. I TALIS 2018, som i de foregående rundene, inngår spørsmål om skoleevalueringer, lærervurderinger sett fra skoleledernes ståsted og vurderinger og tilbakemeldinger sett fra lærernes ståsted. Lærerne har i alle tre runder også fått spørsmål der de ble bedt om å tenke på den vurderingen eller tilbakemeldingen de har mottatt og svare på om den har ført til eller involvert endringer i forhold til ulike sider ved deres egen undervisningspraksis. 
I TALIS 2018 ble rektorene igjen spurt om i hvor stor grad ulike tiltak iverksettes dersom det avdekkes at enkelte lærere kan ha behov for oppfølging. Under temaet «Vurdering av lærere» fikk rektorene spørsmålet: Hvor ofte forekommer følgende ved skolen i etterkant av en formell loerervurdering? Svaralternativene var «aldri», «av og til», «som oftest» og «alltid». I TALIS 2008 og TALIS 2013 var det også spørsmål om tiltak som følge av lærervurderinger. I TALIS 2008 var det blant annet et utsagn som lød: «Jeg, eller andre på skolen, rapporterer dårlige prestasjoner til andre instanser som kan gripe inn (f.eks. på kommunalt nivå)». Det er ikke spesielt vanlig med sanksjonsorienterte virkemidler i TALIS-land. Derfor har vi også valgt å av og til rapportere utsagn som er mer tilpasset den norske skolekonteksten i slike sammenhenger, for eksempel i den norske kortrapporten TALIS 2018 - flere funn fra ungdomstrinnet (Carlsten et al., 2020). Tabell 3 viser at kun de mest relevante utsagnene er inkludert, og at utsagn som «Hvis en lærer ikke presterer tilfredsstillende, vil materielle sanksjoner som f.eks. redusert lønnsvekst bli iverksatt» er utelatt.

Tabell 3 Prosentandelen skoleledere om hyppigheten av ulike oppfølgingstiltak (Carlsten et al., 2020).

\begin{tabular}{lcccc}
\hline Tiltak & Aldri & Av og til & Som oftest & Alltid \\
\hline $\begin{array}{l}\text { Tiltak for å forbedre svakheter i undervisningen blir } \\
\text { diskutert med den enkelte lærer }\end{array}$ & 5 & 47 & 37 & 10 \\
$\begin{array}{l}\text { Lærerens arbeidsoppgaver endres (f.eks. endret } \\
\text { undervisningsplikt eller endret administrativt ansvar) }\end{array}$ & 18 & 73 & 8 & 0 \\
$\begin{array}{l}\text { En mentor/veileder blir utnevnt for å hjelpe læreren } \\
\text { med å forbedre undervisningen }\end{array}$ & 28 & 56 & 15 & 1 \\
$\begin{array}{l}\text { En utviklings- eller opplæringsplan blir utviklet for } \\
\text { den enkelte lærer }\end{array}$ & 34 & 53 & 13 & 1 \\
\begin{tabular}{l} 
Oppsigelse eller ikke fornyet kontrakt \\
\hline
\end{tabular} & 49 & 50 & 1 & 0 \\
\hline
\end{tabular}

Ved å vise til tre slike eksempler som vist i tabellene, har vi her forsøkt å ramme inn arbeidet med hvordan TALIS-undersøkelsen definerer og prioriterer spørsmål om profesjonelle fellesskap. Slike spørsmål skulle både være internasjonalt komparative mellom 48 land og samtidig sensitive til den norske skolesektoren. Der internasjonale hensyn må tas i selve spørreundersøkelsen, og der spørsmål kan oppfattes som lite tilpasset et norsk ungdomstrinn, er det likevel mulig å legge til noen få relevante 
spørsmål og utsagn som tar opp tidligere norske hovedfunn. Et eksempel på dette er utsagnet: «Diskuterer undervisningsmetoder egnet for å motivere elever som viser svak interesse for skolearbeidet».

Vi har også vist at der det ikke er mulig å ta ut spørsmål som vi på forhånd vet er mindre relevante for den norske konteksten, så kan vi velge å fremheve det som er mest relevant i den norske rapporteringen. Alle data og spørreskjema er likevel åpne og tilgjengelige for dem som måtte ønske innsyn, eller som ønsker å bruke data til videre forskningsformål. Spørreskjemaene finnes blant annet på OECDs nettsider. ${ }^{1}$

\section{Verdien av ulike samarbeidsformer i skolen}

Ikke alle former for samarbeid har like stor betydning for elevenes læring. Som det påpekes i stortingsmeldingen Loerelyst - tidlig innsats og kvalitet $i$ skolen, er det først når det profesjonelle samarbeidet er orientert mot å utvikle undervisningen at det får betydning for elevenes læringsutbytte. Med henvisning til Hattie (2015) utdypes det i meldingen at velfungerende profesjonsfellesskap mellom lærere og ledere fører til at de føler et felles ansvar for elevenes læring, at de er opptatt av å dokumentere læringsresultater, at de samarbeider for å utvikle en felles forståelse av hvordan praksis i klasserommet kan forbedres, at de planlegger undervisningsopplegg og pedagogiske strategier i fellesskap, evaluerer effektene av undervisningen, og at de deler og videreutvikler undervisning som viser seg virkningsfull (Meld. St. 21 (2016-2017)).

I tabell 1 over har vi vist hvordan spørsmål i TALIS 2018 kategoriseres som praktisk/koordinerende samarbeid og som samarbeid knyttet til undervisningen, der sistnevnte kategori er den som ligger tettest på kollegasamarbeid som antas å ha størst betydning for elevenes læring. Tabellen viser likevel at samarbeidet på ungdomstrinnet i første rekke preges av praktiske og koordinerende aktiviteter, som for eksempel deltakelse på teammøter, utveksling av undervisningsmateriell og diskusjon om utviklingen til bestemte elever. At praktisk/koordinerende samarbeid er

1 http://www.oecd.org/education/school/talis2018questionnaires.htm 
hyppigst brukt praksisform har vært et fremtredende funn siden TALIS 2008.

Samarbeid om undervisning forekommer mye sjeldnere i Norge. Tabell 1 viser for eksempel at nesten hver fjerde lærer rapporterer at de aldri observerer andre læreres undervisning og gir tilbakemelding. Heller ikke i de andre nordiske landene er det noen kultur for å gi tilbakemelding på bakgrunn av observasjon av undervisning (Carlsten et al., 2020). Slikt samarbeid vet vi ville være egnet til å utveksle kunnskap som kan bidra til å forbedre undervisningen, spesielt gjennom å støtte nye ideer og utfordre eksisterende praksis (Jensen \& Cooper, 2015). Her viser det konseptuelle rammeverket i TALIS 2018 til et potensiale for analytiske sammenhenger mellom kollegasamarbeid og innovasjon i skolen (Ainley \& Carstens, 2017).

Det konseptuelle rammeverket til TALIS 2018 påpeker at lærersamarbeid er en kompleks prosess som berører svært ulike tema som undervisningspraksis, læring og tilfredshet. Ikke minst fremheves referanser til forskning som viser at lærersamarbeid har betydning for utvikling av en felles kunnskapsbase, og at det gir rom for kollektive refleksjoner knyttet til profesjonell utvikling og elevenes læringsresultater. Her ser vi at argumentasjon og henvisninger til forskning fra TALIS 2008 og frem til nå ligger tett på norske policyprinsipper, som for eksempel i strategien for ungdomstrinnet (Kunnskapsdepartementet, 2012) og satsingen på skolebasert kompetanseutvikling i Ungdomstrinn i utvikling (Lødding et al., 2018), samt sentrale oppsummeringer fra ekspertgruppen om lærerrollen (Dahl et al., 2016). Så er det også slik at OECD i noen tilfeller bidrar aktivt i grunnlagsarbeid for medlemslandenes egen policyutvikling, og forskere og andre aktører fra Norge bidrar inn i OECDs utviklingsarbeid. Det kan gjøre at nasjonal og internasjonal policy på dette feltet konvergerer på flere punkter.

At det er noen klare sammenhenger mellom norsk policyutvikling, internasjonal spørsmålsutvikling i TALIS og tilhørende svar, ser vi ikke minst når det gjelder et område som kollektiv vurderingspraksis. Norske lærere samarbeider i langt større grad med andre lærere ved skolen enn det nordiske kolleger gjør for å sikre felles standarder for elevvurdering. Når vi vet at det har vært lagt stor vekt på å etablere en god felles 
vurderingspraksis gjennom den nasjonale satsingen Vurdering for loering 2010-2018, kan det være grunn til å anta at dette gir noe av forklaringen på at Norge er det landet som har høyest andel lærere som samarbeider med kolleger for å sikre en god elevvurdering, slik det fremkommer av data fra TALIS 2018.

\section{Sammenhenger mellom tilbakemeldingskultur og profesjonell utvikling}

For å etablere en samarbeidskultur ved skolen har vi tidligere påpekt at det er vesentlig at rektor legger til rette for samarbeid mellom lærerne. Som det blir påpekt i det konseptuelle rammeverket for TALIS 2018, viser forskning at det er en sterk sammenheng mellom lærerkvalitet og elevenes læringsutbytte (Ainley \& Carstens, 2017). Henvisningen til denne empirisk funderte enigheten viser at det er stor interesse for måter læreres profesjonelle utvikling og tilbakemeldinger fra rektor kan bidra til læreres læring, og hvordan dette igjen kan forbedre undervisning og læring.

I både TALIS 2008 og 2013 inngikk slike spørsmål om profesjonsutvikling og tilbakemelding som to separate tema. I TALIS 2018 ble de to kategoriene konseptuelt tydeligere slått sammen. Formålet var å tydeliggjøre at slike spørsmål om tilbakemelding og vurdering henger sammen med læreres livslange læring, og å muliggjøre en relasjon til spørsmål som handlet om læreres profesjonspraksis og til spørsmål om innovasjon i skolen (Ainley \& Carstens, 2017).

Et hovedfunn i den norske rapporteringen fra TALIS 2008 var at ungdomstrinnet var preget av en svak oppfølgingskultur:

Norsk skoles store utfordring, slik det fremstår av resultatene fra TALIS, er en svakt utviklet oppfølgingskultur, en relativt svak pedagogisk skoleledelse og et system for kompetanseheving blant lærerne, som med fordel kan styrkes. Tilbakemelding, evaluering og oppfølging ser ofte ut til å mangle, både fra skoleeier til skoleleder, fra skoleleder til lærer og fra lærer til elev. Selv om vi må advare mot å forveksle hyppighet med kvalitet, gir undersøkelsen klare indikasjoner på at norske lærere i mindre grad følger opp elevenes arbeid og læring enn hva som er tilfelle i mange andre land. Også oppfølgingen og tilbakemeldingen 
fra skolelederne til lærerne på deres arbeid er svak. Norge peker seg ut i sammenlikning med andre land ved at skolelederne er tydelige som administrative ledere, men samtidig er deres pedagogiske lederskap mindre klart. (Vibe et al., 2009, s. 9)

I etterkant av TALIS 2008 ble det brukt mye ressurser på og gitt mye oppmerksomhet til temaet «tilbakemeldingskultur» i norsk skole (Utdanningsdirektoratet, 2013). Funn fra TALIS 2013 viste at de aller fleste lærere hadde mottatt en form for vurdering og tilbakemelding på arbeidet sitt. Det var kun et mindretall av lærerne som ikke hadde fått noen form for tilbakemelding. Gjennomsnittet for TALIS-land var $14 \%$, mens det i Norge var kun 6 \% som ikke hadde mottatt noen form for tilbakemelding. Til sammenlikning viste data fra TALIS 2013 at ca. $30 \%$ av de finske og de islandske lærerne ikke fått noen form for tilbakemelding (Caspersen et al., 2014). Likevel viste den internasjonale OECD-rapporten samme år at det i Norge, i likhet med de andre nordiske land med unntak av Danmark, var slik at tilbakemeldingen i mindre grad hadde vært positiv for læreres kompetanseutvikling (OECD, 2014). Med andre ord kunne vi i TALIS 2013-analysene konkludere med at mange lærere fikk tilbakemelding på arbeidet, men at det som skjedde i etterkant av en slik vurdering var mindre synlig i Norge enn i de fleste andre deltakerland (Caspersen et al., 2014).

Data fra TALIS 2018 viser at $88 \%$ av norske ungdomsskolelærere har mottatt en eller annen form for tilbakemelding på måten de utfører jobben sin, når det spørres generelt om dette. Her samsvarer lærernes svar godt med rektorenes svar når det gjelder rapportert hyppighet av tilbakemeldinger. Norge ligger i 2018 på omtrent samme nivå som Danmark og Sverige, mens det igjen er Finland og Island som kan vise til en betydelig lavere grad av tilbakemelding (Carlsten et al., 2020).

Som nevnt har det vært endringer i måten å stille spørsmål om formell vurdering og spesielt oppfølgingstiltak fra TALIS 2008 og frem til TALIS 2018. Likevel er det en linje som kan gjenkjennes i data fra de tre rundene: Oppfølgingstiltakene som iverksettes forekommer forholdsvis sjeldent. Ikke overraskende er det i Norge mest vanlig med virkemidler som ikke er sanksjonsorienterte, men som nettopp viser til sammenhenger mellom rektorenes tilbakemeldinger og vurderinger av læreres arbeid og mål om 
å fremme et godt og kritisk profesjonsfellesskap. Tiltakene som gjennomføres oftest handler om hvordan en leder eller en kollega kan hjelpe den enkelte lærer videre i egen praksis.

Igjen kan det være mulig å peke på sammenhenger mellom norsk policyutvikling, internasjonal spørsmålsutvikling i TALIS og svarene som har fremkommet. Men mens det for tema om kollegasamarbeid lettere kunne tolkes i samsvarende kategorier, kan det i sammenhenger mellom tilbakemelding, vurdering og profesjonell utvikling være verdt å rette et mer kritisk blikk. Som det ble pekt på i den norske kortrapport 2 fra TALIS 2018, så er det spørsmålsstillinger som ser ut til å gi noen svar man kan nyansere ved å sammenligne med andre spørsmål i samme undersøkelse (Carlsten et al., 2020).

For å starte med norsk policyutvikling: Som nevnt har det vært en stor nasjonal satsing på skolebasert kompetanseutvikling i Norge for å forbedre profesjonsfellesskapet i skolen, ikke minst gjennom Ungdomstrinn i utvikling 2012-2017. En av ambisjonene i denne satsingen har vært å styrke den pedagogiske ledelsen ved skolen. De «tradisjonelle» spørsmålene og tilhørende svar i TALIS angående skoleledelse viser at det kan virke som rektorene fortsatt har lite tid til pedagogisk ledelse i 2018, spesielt når det gjelder tilbakemelding og formell vurdering av lærerne ved skolen. Det er verdt å merke seg spørsmålsstillingen for dette temaet: «Hvor stor prosentandel mener $d u$ at du som rektor anslagsvis benytter til følgende oppgaver ved denne skolen i løpet av et skoleår?» Svarene viser at rektorene bruker en forholdsvis stor del av arbeidstiden på administrative oppgaver; så mye som $62 \%$. Men her må respondentene svare for et helt års arbeid i svært grove kategorier som «administrative oppgaver og møter», «læreplan- og undervisningsrelaterte oppgaver» og «kontakt med elevene».

I samme spørreskjema møter rektorene så spørsmålet: «Angi hvor ofte du engasjerte deg i følgende ved denne skolen i løpet av de siste 12 månedene». Her får rektorene mulighet til å svare ut fra mange flere og mer situasjonsorienterte utsagn, som «Jeg støttet opp om samarbeid mellom lærerne med tanke på å utvikle ny undervisningspraksis», «Jeg forsikret meg om at lærerne tar ansvar for å forbedre sin undervisning» og «Jeg forsikret meg om at lærerne tar ansvar for elevenes læringsresultater». 
Her er det en stor andel rektorer som svarer at de «ofte» gjør dette (henholdsvis $54 \%$, $46 \%$ og $68 \%$ ) (Carlsten et al., 2020).

Det kan selvsagt være mange ulike grunner til at rektorene svarer som de gjør på slike spørsmål. Det innebærer at svarene blir utfordrende å tolke når man sammenligner dem ut fra indikatorer som pedagogisk og administrativ ledelse. Men det kan være grunn til å trekke frem at de sistnevnte utsagnene kan stemme bedre overens med formuleringer og praksis rektorene kan være kjent med fra norsk policyutvikling og egen konkret praksis, slik som en deltakelse i skolebasert kompetanseutvikling i Ungdomstrinn i utvikling vil være et eksempel på. I alle fall kan det være grunner til å reflektere over om det for en profesjonsutøver vil være lettere å svare på spørsmål som viser tydeligere sammenhenger mellom tilbakemeldingskultur og profesjonell utvikling knyttet til avgrensede praksissituasjoner, enn det er å svare på spørsmål som handler om generell tidsbruk i skolen.

\section{Konklusjon}

Vi har brukt dette kapittelet som en anledning til å gå inn i tema om profesjonelle fellesskap på ungdomstrinnet ikke først og fremst gjennom nye analyser av TALIS-data, men ved å forklare hvordan noen av selve spørsmålene til dette temaet er utviklet og hvilke muligheter spørsmål gir for aktuelle svar. Vi har brukt sammenhengen mellom spørsmålsutvikling og tolkningsrom for svar i TALIS til å antyde verdien av ulike måter lærere på ungdomstrinnet samarbeider, og hvordan skoleledere gir tilbakemeldinger og vurderinger som følger opp dette arbeidet for å legge til rette for lærernes videre profesjonsutvikling. Som en avslutning er det verdt å trekke frem at spørsmålene i TALIS-undersøkelsen naturlig nok er ganske generelle på slike felt som handler om performative og organisatoriske sider ved profesjonelle fellesskap på tvers av land, selv om det konseptuelle rammeverket gir gode internasjonale begrunnelser ved utvalg av relevant forskning. I TALIS 2018 er det også tatt inn spørsmål som ikke bare gir selvbekreftende bilder av det norske profesjonsfellesskapet, men som også ser på hvordan rutiner for vurdering av og fornying av eksisterende praksis håndteres. Noen av disse spørsmålene er 
nevnt i dette kapittelet, og andre er godt re-analysert i kapittel 3 i denne boken, der betingelser for utvikling av innovative skolemiljø diskuteres.

Det er imidlertid et nasjonalt tilleggsutsagn som ikke ble tatt med i kapittel 3: "De fleste loererne ved denne skolen er oppdatert på pedagogisk forskning $i$ fagene de underviser i.» Dette utsagnet ble lagt til med begrunnelsen at ensidig oppmerksomhet mot nye lokalt utviklede undervisningsmetoder og åpenhet for forandring burde stilles opp mot et utsagn som vektla verdien av en felles profesjonell kunnskapsbase i innovativ praksis. En kollektiv orientering til innovasjon i skolen ses i nyere forskning og policyutvikling ikke kun som en lokal skolepraksis, men beveger seg i nettverk og på tvers av skoler, regioner og land. Et profesjonsfellesskap skal altså ikke bare være selvbekreftende, men også undersøkende i forhold til egen praksis i lys av andres praksis og den kunnskap som forskning kan legge til grunn for en kollektiv praksis, slik vi nevnte i innledningen og som den korte gjennomgangen av de senere års policyutvikling presiserer.

Internasjonalt skiller Norge seg ut ved å ha den høyeste andelen lærere som deltar i faglig kompetanseutvikling sammen med kolleger, ifølge TALIS-data fra 2018. Det nasjonale tilleggsutsagnet om lærere mener deres eget kollegium er oppdatert på pedagogisk forskning i de fagene de underviser i viser at $53 \%$ er enige i dette, mens $35 \%$ er uenige. Det er grunn til å tro at uklare sammenhenger mellom funn som dette gjenspeiler noe av konklusjonene i kapittel 3, nemlig at det er vanskelig å måle sammenhenger mellom kollegasamarbeid, tilbakemeldinger og respondentenes oppfatninger av et miljø for innovasjon i skolen gjennom noen få utsagn i et storskala-spørreskjema. På den annen side kan nettopp slike uklarheter, som dette kapittelet har pekt på, bidra til å åpne opp for diskusjoner om både begrensninger og verdier en deltakelse i TALIS-undersøkelsen bringer med seg.

TALIS er en undersøkelse som har hatt og har stor innflytelse på norsk policyutvikling. Undersøkelsen har bidratt til økt satsing og bedre tilrettelegging av etter- og videreutdanning, økt satsing og bedre oppfølging av nyutdannede lærere, økt oppmerksomhet på faglige tilbakemeldinger både fra rektor til lærere og fra lærere til elever, og den har gitt innspill til utviklingen av nasjonal rektorutdanning. Det har vært lett 
å finne støtte til undersøkelsen i skolens interesseorganisasjoner. Vi ser også av våre egne metadata at det å delta i TALIS har blitt en del av skolens arbeid som profesjonell organisasjon. I gjennomføringen av TALIS 2008 var det vanskelig å rekruttere skoler, og svar fra deltakere ved samme skole kom inn på svært ulike tidspunkt. Ti år etterpå, i gjennomføringen av TALIS 2018, var det lettere å rekruttere skoler, og felles tidspunkt for besvarelser ved samme skole kan indikere at skolene nå setter av fellestid for å svare på undersøkelsen.

Kapittelet har derfor hatt som mål å synliggjøre for spesielt skoleledere, lærere og lærerstudenter hvordan spørsmål utarbeides og hvordan svarene kan gi bidrag til refleksjon over egen profesjonell praksis. Samtidig har vi ønsket å gi et lite blikk inn i hvordan internasjonale spørreundersøkelser legger noen premisser for politiske føringer med tanke på å forbedre profesjonsfellesskap, og hvordan skolelederes og læreres egne stemmer igjen bidrar til å utvikle skolesektoren i Norge i dag ved å delta.

\section{Referanser}

Ainley, J. \& Carstens, R. (2018). Teaching and Learning International Survey (TALIS) 2018. Conceptual Framework. OECD Education Working Papers, No. 187.

Beninghof, A. M. (2012). Co-teaching that works: Structures and strategies for maximizing student learning. Jossey Bass.

Bjørnsrud, H. (2009). Skoleutvikling - tre reformer for en loerende skole. Gyldendal Akademisk.

Carlsten, T. C., Björnsson, J. K. \& Throndsen, I. (2021). Hovedfunn fra TALIS 2018-undersøkelsen. (I denne boken).

Carlsten, T. C., Throndsen, I. \& Björnsson, J. K. (2020). TALIS 2018 - Flere hovedfunn fra ungdomstrinnet. Universitetet i Oslo. https://hdl.handle.net/11250/2726536

Caspersen, J., Aamodt, P. O., Vibe, N. \& Carlsten, T. C. (2014). Kompetanse og praksis blant norske loerere: Resultater fra TALIS-undersøkelsen i 2013 (NIFU-rapport 41/2014). Nordisk institutt for studier av innovasjon, forskning og utdanning. http://hdl.handle.net/11250/280358

Dahl, T., Askling, B., Heggen, K., Kulbrantstad, L. I., Lauvdal, T., Qvortrup, L., Salvanes, K. G., Skagen. K., Skrøvset, S., Thue, F. W. \& Mausethagen, S. (2016). Om loererrollen. Et kunnskapsgrunnlag. Ekspertgruppa om loererrollen. Fagbokforlaget.

Fuglestad, U., Hoem, T. F. \& Schulz-Heidorf, K. (2017). Lærerens betydning for norske elevers leseresultater - hva forteller PIRLS 2016? I E. Gabrielsen (Red.), 
Klar framgang! Leseferdighet på 4. og 5. trinn i et femtenårsperspektiv (s. 108-131). Universitetsforlaget. https://doi.org/10.18261/9788215030258-2017-7

Goddard, Y., Goddard, R. \& Tschannen-Moran, M. (2007). A theoretical and empirical investigation of teacher collaboration for school improvement and student achievement in public elementary schools. Teachers College Record, 109(4), 877-896.

Hargreaves, A. (1994). Changing teachers, changing times: Teachers' work and culture in the postmodern age. Teachers College Press.

Hattie, J. (2015). What works best in education: The politics of collaborative expertise. Pearson.

Hermansen, H., Lorentzen, M., Mausethagen, S. \& Zlatanovic, T. (2018). Hva kjennetegner forskning på lærerrollen under Kunnskapsløftet? En forskningskartlegging av studier av norske lærere, lærerstudenter og lærerutdannere. Acta Didactica Norge, 12(1). https://doi.org/10.5617/adno.4351

Jensen, B. \& Cooper, S. (2015). TALIS-PISA conceptual framework. EDU/INES/ TALIS (2015)6 / Learning First.

Klette, K. \& Carlsten, T. C. (2012). Knowledge in teacher learning: New professional challenges. I K. Jensen, L. C. Lahn \& M. Nerland (Red.), Professional learning in the knowledge society (s. 69-84). Sense Publishers. https://doi.org/10.1007/978-946091-994-7_4

Kunnskapsdepartementet. (2012). Motivasjon og mestring for bedre loering [Strategi for ungdomstrinnet]. Regjeringen. https://www.regjeringen.no/globalassets/ upload/kd/vedlegg/grunnskole/strategiplaner/f_4276b_strategi_for_ ungdomstrinnet.pdf

Kunnskapsdepartementet. (2014, 30. september). Lorerløftet [Plan/strategi]. https://www.regjeringen.no/no/dokumenter/Larerloftet/id2001933/

Kunnskapsdepartementet. (2015). Kompetanse for kvalitet: Strategi for etter- og videreutdanning. 2012-2015. Regjeringen. https://www.regjeringen.no/globalassets/ upload/kd/vedlegg/f_4269b_kompetanse_for_kvalitet.pdf

Kunnskapsdepartementet. (2017). Verdier og prinsipper for grunnopploeringen overordnet del av loereplanverket [LK20/fagfornyelsen]. Regjeringen. https://www. regjeringen.no/no/dokumenter/verdier-og-prinsipper-for-grunnopplaringen/ id2570003/

Kvam, E. K. (2014). Pedagogiske samtaler: En kvalitativ studie av loerersamarbeid $i$ norsk grunnskole [Doktorgradsavhandling]. Universitetet i Oslo.

Kvam, E. K. (2018). Loereres kollegasamtaler: Om profesjonalitet, loerersamarbeid og utvikling av bedre undervisning. Universitetsforlaget.

Lødding, B., Gjerustad, C., Rønsen, E., Bubikova-Moan, J., Jarness, V. \& Røsdal, T. (2018). Sluttrapport fra evalueringen av virkemidlene $i$ satsingen Ungdomstrinn i utvikling (NIFU-rapport 2018:32). Nordisk institutt for studier av innovasjon, forskning og utdanning. http://hdl.handle.net/11250/2585108 
Meld. St. 22 (2010-2011). Motivasjon - Mestring - Muligheter. Kunnskapsdepartementet. https://www.regjeringen.no/no/dokumenter/meld-st-22-2010-2011/id641251/

Meld. St. 28 (2015-2016). Fag - Fordypning - Forståelse. En fornyelse av Kunnskapsløftet. Kunnskapsdepartementet. https://www.regjeringen.no/no/ dokumenter/meld.-st.-28-20152016/id2483955/

Meld. St. 21 (2016-2017). Loerelyst - tidlig innsats og kvalitet $i$ skolen. Kunnskapsdepartementet. https://www.regjeringen.no/no/dokumenter/meld.-st.-21-2016 2017/id2544344/

Møller, J. (2011). Rektorers profesjonsforståelse - faglig autonomi og administrativ underordning. I J. Møller \& E. Ottesen (Red.), Rektor som leder og sjef. Om styring, ledelse og kunnskapsutvikling i skolen (s. 27-50). Universitetsforlaget.

Møller, J. \& Ottesen, E. (2011). Building leadership capacity: The Norwegian approach. I T. Townsend \& J. MacBeath (Red.), International handbook of leadership for learning (s. 619-634). Springer. https://doi.org/10.1007/978-94-007-1350-5_35

Nilsen, T., Scherer, R. \& Blömeke, S. (2021). Hva fremmer et innovativt klima i skolen, og hvilken betydning har det for læreres undervisning? (I denne boken)

OECD. (2017). Teaching and Learning International Survey (TALIS) 2018. Technical Standards. OECD.

OECD (2014). TALIS 2013 results: an international perspective on teaching and learning (Revised version. ed.). OECD.

St.meld. nr. 30 (2003-2004). Kultur for loering. Kunnskapsdepartementet. https:// www.regjeringen.no/no/dokumenter/stmeld-nr-030-2003-2004-/id404433/

Throndsen, I., Carlsten, T. C. \& Björnsson, J. K. (2019). TALIS 2018 - Første hovedfunn fra ungdomstrinnet. Institutt for lærerutdanning og skoleforskning, Universitetet i Oslo. http://hdl.handle.net/11250/2601320

Timperley, H., Wilson, A., Barrar, H. \& Fung, I. (2007). Teacher professional learning end development: Best evidence synthesis iteration. Ministry of Education. http:// www.oecd.org/education/school/48727127.pdf

Utdanningsdirektoratet. (2013). Tydelig lederskap fremmer gode relasjoner, samarbeid og elevprestasjoner. Forskning Viser, 2013(01). https://www.udir.no/ globalassets/upload/forskning/2013/forskningvisero113_web.pdf

Vescio, V., Ross, D. \& Adams, A. (2008). A review of research on the impact of professional learning communities on teaching practice and student learning. Teaching and teacher education, 24(1), 80-91. https://doi.org/10.1016/j.tate.2007. 01.004

Vibe, N., Aamodt, P. O. \& Carlsten, T. C. (2009). A vore ungdomsskoleloerer i Norge: Resultater fra OECDs internasjonale studie av undervisning og loering (TALIS) (NIFU-rapport 2009:23). Nordisk institutt for studier av innovasjon, forskning og utdanning. http://hdl.handle.net/11250/279818. 


\title{
KAPITTEL 6
}

\section{Nyutdannede læreres opplevelse av læreryrket}

\author{
Christian Brandmo \\ Institutt for spesialpedagogikk, Universitetet i Oslo
}

Dijana Tiplic

Institutt for lærerutdanning og skoleforskning, Universitetet i Oslo

\begin{abstract}
Beginning teachers' job perceptions
Over the last decade, the lack of qualified teachers in schools has been the subject of both research and political debate in many countries. In this study, we have investigated the factors that predict beginning teachers' perceptions of job satisfaction, stress, and thoughts about quitting the job. The sample consisted of a total of 597 beginning teachers (65\% women) from Norway. The results show that women experience higher job satisfaction and more stress at work than men do. The beginning teachers who said teaching was their first choice of career reported higher satisfaction with the profession and had fewer thoughts about quitting. Furthermore, the results show that beginning teachers are more satisfied than their more experienced colleagues with the profession and their school, a trend that was also reported by TALIS 2013. When it comes to beginning teachers' own competence, the results show that self-efficacy in classroom management is significantly related to both higher satisfaction with their school and less stress. Regarding organizational factors, the findings show that commitment to and support from the school organisation are significantly related to higher satisfaction with the workplace. The study has several implications for school leaders and decision makers.
\end{abstract}

Keywords: beginning teachers, job satisfaction, intention to leave

Sitering av denne artikkelen: Brandmo, C. \& Tiplic, D. (2021). Nyutdannede læreres opplevelse av læreryrket. I J. K. Björnsson (Red.), Hva kan vi loere av TALIS 2018? Gode relasjoner som grunnlag for loring (Kap. 6, s. 107-122). Cappelen Damm Akademisk. https://doi.org/10.23865/noasp.123.ch6

Lisens: CC BY-NC-ND 4.0. 


\section{Innledning}

I løpet av det siste tiåret har mangelen på kvalifiserte lærere i skolen vært gjenstand for både forskning og politisk debatt (Brandmo \& Nesje, 2017; Gjefsen et al., 2014). Data fra Kommunenes Sentralforbund for perioden 2006-2011 viste at $1 / 3$ av lærerne sluttet i yrket innen 5 år etter fullført utdannelse (Tiplic et al., 2015). Tidligere forskning har pekt på at nyutdannede opplever et «praksissjokk» (Caspersen \& Raaen, 2014; Veenman, 1984) når de kommer ut $\mathrm{i}$ arbeid etter utdannelsen, og at dette kan være en av årsakene til at mange slutter som lærer etter kort tid. I litteraturen er praksissjokket beskrevet som en overgangsperiode etter utdanning hvor de nye lærerne opplever møtet med skolen og de mange arbeidsoppgavene som overveldende og krevende. I denne studien har vi derfor valgt å studere nyutdannedes opplevelse av loereryrket.

Dette gjør vi gjennom å studere fenomener som tidligere er løftet frem av OECD (2005) som kritiske faktorer for lærergjerningen og læreryrkets attraktivitet. Mer spesifikt har vi valgt å sette søkelys på variabler som kan være indikatorer på hvor krevende nyutdannede lærere opplever jobben i skolen. De fire variablene er a) tilfredshet med skolen, b) tilfredshet med den valgte profesjonen, c) opplevelse av stress og d) tanker om å slutte som lærer. Jobbtilfredshet omhandler lærernes følelsesmessige reaksjoner knyttet til deres jobb og rolle som lærer (Skaalvik \& Skaalvik, 2017). I TALIS-undersøkelsen er dette begrepet delt opp i henholdsvis tilfredshet med skolen de arbeider på og tilfredshet med den valgte profesjonen (læreryrket). Jobbrelatert stress omhandler lærernes jobbrelaterte velvære, og hvorvidt deres fysiske og psykiske helse påvirkes negativt av jobben (Collie et al., 2012; Kyriacou, 1987). Tanker om å slutte i jobben kan defineres som lærernes refleksjoner om å slutte i sin nåværende stilling eller å forlate lærerprofesjonen (Skaalvik \& Skaalvik, 2011; Tiplic et al., 2015). Tidligere forskning har vist at disse variablene er relativt høy korrelerte (Skaalvik \& Skaalvik, 2011; Weiss, 1999), noe som også bekreftes i denne studien. Det vil si at lave skårer på jobbtilfredshet er systematisk relatert til mer opplevd stress og flere tanker om å slutte i jobben.

Basert på tidligere forskning har vi tatt utgangpunkt i både individuelle (f.eks. opplevelse av egen kompetanse) og organisatoriske faktorer (f.eks. opplevelse av støtte fra organisasjonen) som antas å kunne 108 
predikere jobbtilfredshet, stress og tanker om å slutte (f.eks. Bryk et al., 2010; Caspersen \& Raaen, 2014; Roness, 2011; Skaalvik \& Skaalvik, 2010; Tiplic et al., 2015). I tillegg sammenligner vi de nyutdannede lærerne med mer erfarne lærere på de fire utfallsvariablene.

I denne studien bruker vi ulike statistiske analyseteknikker, blant annet regresjonsanalyser der de ovennevnte indikatorene brukes som utfallsvariabler. Vi vil her bemerke at dette ikke nødvendigvis betyr at vi betrakter de uavhengige variablene (prediktorene) som en årsak til utfallsvariablene (jf. kausalslutninger). Derimot tyder teori og tidligere forskning på at flere av de fenomenene som undersøkes i denne studien står i et gjensidig påvirkningsforhold til hverandre (Bandura, 1986; Mathieu et al., 1993). Dette gjelder både mellom individuelle faktorer og mellom individuelle og organisatoriske faktorer. Vi vil også bemerke at vi i denne studien bruker begrepet opplevelse av loereryrket som et samlebegrep på de fire utfallsvariablene som belyses i studien. Dette begrepet må ikke forveksles med det engelske begrepet «job perception», som i den internasjonale forskningslitteraturen (se f.eks. Law \& Wong, 1999) er noe snevrere definert.

\section{Valg og metodisk tilnærming}

Utvalget består av til sammen 597 (65 \% kvinner) nyutdannede ungdomsskolelærere fra hele Norge. Nyutdannede lærere er definert som de lærerne som hadde fra o til 3 års erfaring som lærere. I noen analyser ble denne gruppen sammenlignet med mer erfarne lærere, henholdsvis «middels erfarne», som hadde fra 4 til 6 års erfaring, og "erfarne», som hadde 7 års erfaring eller mer.

Analysene består både av begreper som inngår i den internasjonale studien og begreper som bare ble målt i den norske undersøkelsen. De internasjonale begrepene er konstruert med de samme spørsmål («items») som i den internasjonale studien. Alle begrepene ble testet med hensyn til målefeil og funnet reliable. For sammenligning av grupper med hensyn til kjønn, erfaring og motivasjon ble det brukt t-test med programmet IDB Analyzer. Regresjonsanalyse med latente variabler ble brukt for å teste sammenhenger mellom ulike variabler, både individuelle og 
organisatoriske. Til disse analysene ble programmet Mplus benyttet. På grunn av at mange av skolene hadde få nyutdannede lærere (51 av 163 skoler hadde bare én nyutdannet lærer), ble det ikke benyttet flernivåanalyse i denne studien. For å korrigere for eventuelle estimeringsfeil knyttet til lærenes skoletilhørighet, ble det brukt robust statistikk (Huber-White standardfeil).

I de beskrivende analysene er det ikke gjort noen korrigeringer for manglende data, da andel manglende data var relativt lav. Men i regresjonsanalysene er manglende data estimert med «Full MaximumLikelihood» (FML), noe som vil si at manglende data blir estimert på bakgrunn av alle svarene i datamatrisen.

Den norske delen av TALIS baserer seg på et representativt utvalg av norske lærere. Utvelging av lærerne foregår imidlertid som en to-trinns prosess, der man først velger ut skoler tilfeldig proporsjonalt med skolestørrelse, for deretter å velge ut tilfeldig de lærerne som skal delta innenfor hver skole. Som en konsekvens av dette utvalgsdesignet, blir svarene til hver enkelt lærer vektet forskjellig i analysene. Dette for at resultatene, samlet sett, skal kunne gjøres gyldige for hele populasjonen av norske lærere (se TALIS 2018 teknisk rapport for detaljer).

Denne vektingen er også brukt for underutvalget av nyutdannede lærere. Siden vektene er beregnet for bruk på hele utvalget av lærer, og ikke på underutvalget av nyutdannede, er det noe større usikkerhet knyttet til estimatene for nyutdannede lærere. I tillegg vil vi nevne at våre analyser bygger på antakelser om kausale sammenhenger, men at forskningsdesignet som brukes i TALIS (tverrsnittstudie) ikke tillater oss å trekke sikre konklusjoner om kausalitet (årsak - virkning) mellom variablene.

\section{Opplevelse av yrket: Sammenheng med kjønn og erfaring}

Innledningsvis analyserte vi kjønnsforskjeller knyttet til de fire avhengige variablene. T-test viste at det var signifikante forskjeller mellom kjønnene for to av utfallsvariablene (se tabell 1). Kvinner rapporterte 
høyere tilfredshet med skolen og mer stress i jobben. Dette bekrefter funn i tidligere forskning som viser at kvinnelige lærere rapporter høyere jobbtilfredshet, men også mer opplevd stress (Klassen \& Chiu, 2010). TALIS 2013 viste også at kvinner rapporterte høyere jobbtilfredshet enn menn i land der majoriteten av lærerne var kvinner (OECD, 2014, s. 189). Når det gjelder tanker om å slutte, viser tidligere forskning at kjønnsforskjellen ofte forsvinner når det blir kontrollert for jobbtilfredshet (Arnup \& Bowles, 2016; Miller \& Wheeler, 1992).

Tabell 1 Kjønnsforskjeller på utfallsvariablene.

\begin{tabular}{lccccc}
\hline Variabel & Kvinner & & Menn & & t-verdi \\
\hline Tilfredshet med skolen & 3,42 & 0,48 & 3,29 & 0,55 & $2,80^{\star \star}$ \\
Tilfredshet med profesjon & 3,25 & 0,63 & 3,15 & 0,64 & 1,46 IS \\
Opplevelse av stress & 2,01 & 0,57 & 1,86 & 0,55 & $2,63^{\star \star}$ \\
Tanker om å slutte i jobben & 1,33 & 0,60 & 1,45 & 0,78 & 1,56 IS \\
\hline
\end{tabular}

Note: Standardavvik i kursiv; IS = Ikke signifikant, ${ }^{\star \star} p<0,01$; Svarskala for Tilfredshet med skolen og Tilfredshet med profesjon: 1 - Svært uenig, 2 - Uenig, 3 - Enig, 4 - Svært enig; Svarskala for Opplevelse av stress og Tanker om å slutte jobben: 1 - Ikke i det hele tatt, 2 - I noen grad, 3 - I stor grad, 4 - I svært stor grad.

Vi sammenlignet også skårene på utfallsvariablene med mer erfarne lærere (se tabell 2). Analysen viser at nyutdannede lærere er mer tilfredse med yrket enn sine mer erfarne kolleger, en tendens som også tidligere er dokumentert i TALIS 2013 (OECD, 2014). De nyutdannede lærerne er også mer tilfreds med skolen de arbeider på enn de mest erfarne. I tillegg rapporterte de nyutdannede lærerne at de hadde færre tanker om å slutte enn sine mer erfarne kolleger. Disse resultatene er overraskende, siden det ofte er påpekt at nyutdannede er mer sårbare i begynnelsen av karrieren jf. opplevelse av praksissjokk og utfordringer knyttet til tilpasning i et nytt arbeidsmiljø (Caspersen \& Raaen, 2014; Tiplic et al., 2015; Veenman, 1984).

Det var ingen forskjeller mellom gruppene med hensyn til opplevelse av stress, noe som også korresponderer med funn i tidligere forskning (f.eks. Fisher, 2011). Likevel vet vi forholdvis lite om hvorvidt det er de samme faktorene som fører til stress hos nyutdannede og mer erfarne lærere. Følgelig er dette et område som det bør forskes mer på. 
Tabell 2 Sammenligning mellom nytdannede og mer erfarne lærere - gjennomsnittsverdier.

\begin{tabular}{|c|c|c|c|c|c|c|c|}
\hline \multirow{2}{*}{$\begin{array}{l}\text { Variabel } \\
\begin{array}{l}\text { Tilfredshet med } \\
\text { skolen }\end{array}\end{array}$} & \multicolumn{2}{|c|}{$\begin{array}{c}\text { Gruppe } 1 \\
\text { Nyutdannede }\end{array}$} & \multicolumn{2}{|c|}{$\begin{array}{c}\text { Gruppe } 2 \\
\text { Middels erfarne }\end{array}$} & \multicolumn{2}{|c|}{$\begin{array}{l}\text { Gruppe } 3 \\
\text { Erfarne }\end{array}$} & \multirow{2}{*}{$\begin{array}{c}\begin{array}{c}\text { t-verdier mellom } \\
\text { grupper }\end{array} \\
\text { (1 og 2; } 1 \text { og } \mathbf{3} ; \mathbf{2} \text { og } \mathbf{3}) \\
1,84 \text { IS; } 3,95^{\star \star} ; 1,37 \text { IS. }\end{array}$} \\
\hline & 3,37 & 0,51 & 3,29 & 0,54 & 3,25 & 0,51 & \\
\hline $\begin{array}{l}\text { Tilfredshet med } \\
\text { profesjon }\end{array}$ & 3,21 & 0,63 & 3,12 & 0,62 & 3,08 & 0,62 & $2,27^{\star} ; 3,82^{\star \star} ; 0,97$ IS. \\
\hline $\begin{array}{l}\text { Opplevelse av } \\
\text { stress }\end{array}$ & 1,96 & 0,56 & 1,99 & 0,55 & 1,96 & 0,56 & 0,75 IS; 0,06 IS; 0,82 IS. \\
\hline $\begin{array}{l}\text { Tanker om å } \\
\text { slutte i jobben }\end{array}$ & 1,37 & 0,67 & 1,56 & 0,71 & 1,54 & 0,74 & $3,74^{\star \star} ; 4,39^{\star \star} ; 0,49$ IS. \\
\hline
\end{tabular}

Note: Gruppe $1(n=568)=0-3$ års erfaring, Gruppe $2(n=488)=4-6$ års erfaring, Gruppe $3(n=2829)=7$ år eller mer erfaring. Standardavvik i kursiv; IS = Ikke signifikant, ${ }^{*} p<0,05,{ }^{* *} p<0,01$.

\section{Opplevelse av yrket: Sammenheng med motivasjon for å bli lærer}

Tidligere forskning har påpekt at læreres indre og ytre motivasjon for å bli lærer er relatert til jobbtilfredshet og hvor lenge lærerne blir i profesjonen (Ainley \& Carstens, 2018; Brandmo \& Nesje, 2017; Watt et al., 2012). Basert på denne antakelsen, undersøkte vi hvorvidt lærerne som hadde læreryrket som første karrierevalg skåret forskjellig fra de som ikke hadde læreryrket som førstevalg (se tabell 3). Resultatene viser at de som hadde læreryrket som førstevalg er mer fornøyd med læreryrket som profesjon og har færre tanker om å slutte. Det var ingen forskjell mellom gruppene når det gjelder tilfredshet med skolen og opplevelse av stress.

Tabell 3 Læreryrket som førstevalg - sammenligning av grupper med (Ja) og uten (Nei) som førstevalg.

\begin{tabular}{llllll}
\hline Variabel & \multicolumn{2}{c}{ Ja (57\%) } & \multicolumn{2}{c}{ Nei (43\%) } & t-verdi \\
\hline Tilfredshet med skolen & 3,41 & 0,48 & 3,32 & 0,56 & 1,43 IS \\
Tilfredshet med profesjon & 3,32 & 0,55 & 3,05 & 0,72 & $4,04^{\star \star}$ \\
Opplevelse av stress & 1,92 & 0,54 & 2,02 & 0,59 & 1,45 IS \\
Tanker om å slutte i jobben & 1,24 & 0,51 & 1,57 & 0,83 & $3,76^{\star \star}$ \\
\hline
\end{tabular}

Note: Standardavvik i kursiv; IS = Ikke signifikant, ${ }^{* \star} p<0,01$

I forskningslitteraturen er motivasjon for å bli lærer ofte delt inn i flere underkategorier. TALIS bruker tre kategorier: a) oppfatninger om egen kompetanse reflekterer hvorvidt lærerne mener de har de nødvendige egenskapene for å bli gode lærere (f.eks. at de oppfatter seg selv som gode 
til å undervise); b) personlig nytte reflekterer hvorvidt læreryrket samsvarer med personlige mål og ønsket livssituasjon (f.eks. trygg jobb, sikker inntekt, ferier); c) altruistisk motivasjon reflekterer muligheten til å gjøre noe samfunnsnyttig (f.eks. påvirke barn og unges utvikling).

Resultatene viser at de som innledningsvis ønsket å bidra til samfunnet, også kalt altruistisk motivasjon, rapporterte høyere tilfredshet med både skolen de jobbet på og læreryrket som profesjon (se tabell 4). Videre rapporterte de lærerne som innledningsvis opplevde å ha egenskaper til en god lærer, høyere tilfredshet med læreryrket som profesjon. De nevnte motivasjonsvariablene forklarte henholdsvis $4 \%$ og $11 \%$ av variansen i tilfredshet med skolen og tilfredshet med profesjonen.

Tabell 4 Regresjonsanalyse med to typer jobbtilfredshet som avhengig variabel.

\begin{tabular}{lccc}
\hline Variabler & $\boldsymbol{\beta}$ & Sig. & $\boldsymbol{R}^{\mathbf{2}}$ \\
\hline Tilfredshet med skolen & & & \\
Opplevelse av å ha egenskapene til en god lærer & 0,00 & IS & \\
Motivasjon for å bli lærer - personlig nytte & 0,00 & IS & \\
Motivasjon for å bli lærer - til nytte for samfunnet & 0,20 & 0,00 & $4 \%$ \\
Tilfredshet med profesjon & & & \\
Opplevelse av å ha egenskapene til en god lærer & 0,17 & 0,01 & \\
Motivasjon for å bli lærer - personlig nytte & $-0,08$ & IS & \\
Motivasjon for å bli lærer - til nytte for samfunnet & 0,22 & 0,00 & $11 \%$ \\
\hline
\end{tabular}

Note: $\beta=$ standardisert regresjonskoeffisient. IS = Ikke signifikant. Modell tilpasning: $x^{2}(125 \mathrm{df})=265, p=0,00$; RMSEA $=0,04 ; \mathrm{CFI}=0,95 ; \mathrm{SRMR}=0,05$.

Basert på tidligere funn (f.eks. Watt et al., 2012) forventet vi at lærerne som hadde høy motivasjon for valg av læreryrket ville være mer motstandsdyktige mot stress og samtidig færre ha tanker om å slutte. Verken opplevelse av stress i jobben eller tanker om å slutte ser ut til å være assosiert med motivasjon for å bli lærer (se tabell 5 og 6).

Tabell 5 Regresjonsanalyse med Opplevelse av stress som avhengig variabel.

\begin{tabular}{llll}
\hline Variabler & $\boldsymbol{\beta}$ & Sig. & $\boldsymbol{R}^{\mathbf{2}}$ \\
\hline Opplevelse av stress & & & \\
Opplevelse av å ha egenskapene til en god lærer & $-0,09$ & IS \\
Motivasjon for å bli lærer - personlig nytte & 0,03 & IS \\
Motivasjon for å bli lærer - til nytte for samfunnet & 0,05 & IS & $1 \%$ \\
\hline
\end{tabular}

Note: IS = Ikke signifikant. Modell tilpasning: $x^{2}(71 \mathrm{df})=89, p=0,07 ; \mathrm{RMSEA}=0,02 ; \mathrm{CFI}=0,99 ; \mathrm{SRMR}=0,03$. 
Tabell 6 Regresjonsanalyse med Tanker om å slutte som avhengig variabel.

\begin{tabular}{lccc}
\hline Variabler & $\boldsymbol{\beta}$ & Sig. & $\boldsymbol{R}^{\mathbf{2}}$ \\
\hline Tanker om å slutte & & & \\
Opplevelse av å ha egenskapene til en god lærer & $-0,06$ & IS \\
Motivasjon for å bli lærer - personlig nytte & 0,04 & IS \\
Motivasjon for å bli lærer - til nytte for samfunnet & $-0,12$ & IS & $3 \%$ \\
\hline
\end{tabular}

Note: IS = Ikke signifikant. Modell tilpasning: $x^{2}(48 \mathrm{df})=80, p=0,00 ; \mathrm{RMSEA}=0,03 ; \mathrm{CFI}=0,98 ;$ SRMR = 0,04.

\section{Opplevelse av yrket: Sammenheng med opplevelse av egen kompetanse}

Lærenes mestringsforventninger omhandler lærernes oppfatninger av egen kompetanse. I litteraturen er dette begrepet ofte delt inn i flere underbegreper og operasjonalisert i forhold til ulike oppgaver, situasjoner og kontekster (Skaalvik \& Skaalvik, 2007; Tiplic et al., 2015). I denne studien har vi valgt å fokusere på tre underbegreper: a) mestringsforventninger for klasseledelse reflekterer lærerens opplevde kompetanse for å opprettholde orden og disiplin i klasserommet; b) mestringsforventninger for å skape elevengasjement reflekterer lærerens opplevde kompetanse for å støtte og motivere elevene i sin læring; c) mestringsforventninger for flerkulturelle omgivelser reflekterer lærerens opplevde kompetanse for å håndtere utfordringer i flerkulturelle klasserom (f.eks. tilpasse undervisning til elever med ulik etnisk bakgrunn eller bidra til bevissthet rundt kulturelle forskjeller og fordommer). Det skal her nevnes at et annet underbegrep, mestringsforventninger for undervisning, ble ekskludert fra videre analyse på grunn av manglende reliabilitet.

Resultatene viser at mestringsforventninger for klasseledelse er en kritisk faktor (se tabell 7 og 8). Mestring av klasseledelse predikerer signifikant både høyere tilfredshet med skolen og lavere opplevelse av stress.

Resultatene viser også at lærerens mestringsforventninger ikke har noen sammenheng med de nyutdannedes tanker om å slutte (se tabell 9). Dette funnet er i samsvar med funn i tidligere forskning (Tiplic et al., 2015). 
Tabell 7 Regresjonsanalyse med to typer jobbtilfredshet som avhengig variabel.

\begin{tabular}{lccc}
\hline Variabler & $\boldsymbol{\beta}$ & Sig. & $\boldsymbol{R}^{\mathbf{2}}$ \\
\hline Tilfredshet med skolen & & \\
Mestringsforventninger for klasseledelse & 0,28 & 0,00 \\
Mestringsforventninger for å skape elevengasjement & $-0,12$ & IS \\
Mestringsforventninger for flerkulturelle omgivelser & 0,07 & IS & $6 \%$ \\
Tilfredshet med profesjon & & \\
Mestringsforventninger for klasseledelse & 0,12 & IS \\
Mestringsforventninger for å skape elevengasjement & 0,14 & IS \\
Mestringsforventninger for flerkulturelle omgivelser & 0,02 & IS & $6 \%$ \\
\hline
\end{tabular}

Note: IS = Ikke signifikant. Modell tilpasning: $x^{2}(179 \mathrm{df})=423, p=0,00 ; \mathrm{RMSEA}=0,05 ; \mathrm{CFI}=0,92 ;$ SRMR = 0,06.

Tabell 8 Regresjonsanalyse med Opplevelse av stress som avhengig variabel.

\begin{tabular}{lccc}
\hline Variabler & $\boldsymbol{\beta}$ & Sig. & $\boldsymbol{R}^{\mathbf{2}}$ \\
\hline Opplevelse av stress & & & \\
Mestringsforventninger for klasseledelse & $-0,22$ & 0,01 & \\
Mestringsforventninger for å skape elevengasjement & 0,02 & IS & \\
Mestringsforventninger for flerkulturelle omgivelser & $-0,02$ & IS & $5 \%$ \\
\hline
\end{tabular}

Note: IS = Ikke signifikant. Modell tilpasning: $x^{2}(113 \mathrm{df})=245, p=0,00 ;$ RMSEA = 0,05; CFI = 0,94; SRMR = 0,05.

Tabell 9 Regresjonsanalyse med Tanker om å slutte som avhengig variabel.

\begin{tabular}{llll}
\hline Variabler & $\boldsymbol{\beta}$ & Sig. & $\boldsymbol{R}^{\mathbf{2}}$ \\
\hline Tanker om å slutte & & & \\
Mestringsforventninger for klasseledelse & $-0,08$ & IS & \\
Mestringsforventninger for å skape elevengasjement & $-0,11$ & IS & \\
Mestringsforventninger for flerkulturelle omgivelser & 0,05 & IS & $2 \%$ \\
\hline
\end{tabular}

Note: IS = Ikke signifikant. Modell tilpasning: $x^{2}(84 \mathrm{df})=183, p=0,00 ;$ RMSEA = 0,05; CFI = 0,95; SRMR = 0,05.

\section{Opplevelse av yrket: Sammenheng med organisatoriske faktorer}

Nyere forskning indikerer at organisatoriske faktorer kan bidra til å forbedre og opprettholde læreres jobbmotivasjon (Ainley \& Carstens, 2018; Caspersen \& Raaen, 2014; Tiplic et al., 2015). I denne studien har vi inkludert følgende organisatoriske faktorer: a) hvorvidt de nyutdannede har en mentor; b) opplevelse av støtte fra organisasjonen som reflekterer lærernes opplevelse av støtte, hjelp og omsorg fra kolleger og skolen i utfordrende 
situasjoner; c) opplevelse av tilknytning til organisasjonen som reflekterer lærerens opplevelse av å være inkludert og følelsesmessig tilknyttet til skolen; d) opplevelse av kollektiv innovasjon som reflekterer lærernes opplevelse av skolens fleksibilitet til å tilpasse seg endringer i samfunnet; e) deltakelse $i$ samarbeidsaktiviteter som reflekterer lærernes engasjement i samarbeid med kolleger når det gjelder undervisning og profesjonell utvikling; f) opplevelse av tillit til rektor som reflekterer lærernes opplevelse av at rektor er opptatt av de ansattes trivsel og muligheter for profesjonell utvikling.

Resultatene viser at $26 \%$ av de nyutdannede lærerne rapporterte at de hadde en mentor. Dette ser ut til å være noe lavere enn det som ble rapportert i den norske TALIS-undersøkelsen (38\%) fra 2013 (OECD, 2014). Videre viser resultatene at de som har mentor har marginalt færre tanker om å slutte (se tabell 10). Det var ingen signifikante forskjeller mellom gruppene når det gjelder tilfredshet med skolen, eller profesjonen, og opplevelse av stress. Disse resultatene bør imidlertid tolkes med varsomhet siden det bare var $26 \%$ av deltakerne som rapportere at de hadde mentor, og det statistiske sammenligningsgrunnlaget dermed er begrenset.

Tabell 10 Mentorskap - sammenligning på utfallsvariablene mellom de som har mentor (Ja) og de som ikke har mentor (Nei).

\begin{tabular}{lccc}
\hline Variabel & Ja (26\%) & Nei (74\%) & t-verdi \\
\hline Tilfredshet med skolen & 3,40 & 3,37 & 0,53 IS \\
Tilfredshet med profesjon & 3,27 & 3,20 & 0,96 IS \\
Opplevelse av stress & 1,99 & 1,95 & 0,69 IS \\
Tanker om å slutte i jobben & 1,27 & 1,41 & $2,01^{\star}$ \\
\hline
\end{tabular}

Note: IS = Ikke signifikant; ${ }^{\star} p<0,05$.

Når det gjelder andre organisatoriske faktorer (se tabell 11), så viser resultatene i denne studien at opplevelse av støtte fra organisasjonen og opplevelse av tilknytning til organisasjonen signifikant predikerer tilfredshet med skolen. I tillegg predikeres tilfredshet med skolen av lærernes opplevelse av et kollektivt og innovativt arbeidsmiljø. Dette er funn som er i samsvar med tidligere forskning (Tiplic et al., 2015). Når det gjelder tilfredshet med profesjonen, viser resultatene kun én signifikant sammenheng, nemlig med opplevelse av tilknytning til organisasjonen.

Det er verdt å merke seg at deltakelse i samarbeidsaktiviteter ikke hadde noen sammenheng med de nyutdannedes jobbtilfredshet. Ellers 
viser analysene at opplevelse av tillit til rektor er signifikant korrelert med lærernes jobbtilfredshet. I regresjonsanalysen blir imidlertid denne sammenhengen ikke signifikant på grunn av høy korrelasjon mellom opplevelse av tillit til rektor og andre prediktorvariabler.

Tabell 11 Regresjonsanalyse med to typer jobbtilfredshet som avhengig variabel.

\begin{tabular}{lccc}
\hline Variabler & $\boldsymbol{\beta}$ & Sig. & $\boldsymbol{R}^{\mathbf{2}}$ \\
\hline Tilfredshet med skolen & & & \\
Opplevelse av støtte fra organisasjonen & 0,26 & 0,00 & \\
Opplevelse av tilknytning til organisasjonen & 0,45 & 0,00 & \\
Opplevelse av kollektiv innovasjon & 0,16 & 0,00 & \\
Deltakelse i samarbeidsaktiviteter & $-0,05$ & IS & 56\% \\
Opplevelse av tillit til rektor & 0,13 & IS & \\
Tilfredshet med profesjon & & & \\
Opplevelse av støtte fra organisasjonen & 0,15 & IS & \\
Opplevelse av tilknytning til organisasjonen & 0,25 & 0,00 & \\
Opplevelse av kollektiv innovasjon & 0,08 & IS & \\
Deltakelse i samarbeidsaktiviteter & $-0,03$ & IS & \\
Opplevelse av tillit til rektor & 0,06 & IS & $16 \%$ \\
\hline
\end{tabular}

Note: IS = Ikke signifikant. Modell tilpasning: $x^{2}(443 \mathrm{df})=875, p=0,00 ; \mathrm{RMSEA}=0,04 ; \mathrm{CFI}=0,92 ;$ SRMR = 0,06.

Tidligere forskning indikerer en negativ sammenheng mellom støttende arbeidsmiljø og lærernes opplevelse av jobbrelatert stress (Skaalvik \& Skaalvik, 2016). Dette bekreftes i denne studien, der resultatene viser at de nyutdannede lærerne som opplever støtte fra organisasjonen rapporterer lavere stress. De andre faktorene (se tabell 12) var ikke prediktorer for stress.

Tabell 12 Regresjonsanalyse med Opplevelse av stress som avhengig variabel.

\begin{tabular}{lccc}
\hline Variabler & $\boldsymbol{\beta}$ & Sig. & $\boldsymbol{R}^{\mathbf{2}}$ \\
\hline Opplevelse av stress & & \\
Opplevelse av støtte fra organisasjonen & $-0,18$ & 0,02 \\
Opplevelse av tilknytning til organisasjonen & $-0,10$ & IS \\
Opplevelse av kollektiv innovasjon & $-0,11$ & IS \\
Deltakelse i samarbeidsaktiviteter & 0,11 & IS \\
Opplevelse av tillit til rektor & $-0,07$ & IS & $12 \%$ \\
\hline
\end{tabular}

Note: IS = Ikke signifikant. Modell tilpasning: $x^{2}(335 \mathrm{df})=642, p=0,00 ;$ RMSEA =0,04; CFI = 0,93; SRMR = 0,06. 
Når det gjelder de nyutdannedes tanker om å slutte, så viser resultatene at kun én av organisasjonsfaktorene predikerte stress signifikant, nemlig opplevelse av tilknytning til organisasjonen (se tabell 13). Dette funnet er også rapportert i tidligere studier (Tiplic et al., 2015, 2016). Jamfør tidligere forskning var det overraskende at ingen av de andre prediktorvariablene var signifikant relatert til tanker om å slutte. Enkel korrelasjonsanalyse bekreftet også at disse sammenhengene var svake.

Tabell 13 Regresjonsanalyse med Tanker om å slutte som avhengig variabel.

\begin{tabular}{|c|c|c|c|}
\hline Variabler & $\beta$ & Sig. & $R^{2}$ \\
\hline \multicolumn{4}{|l|}{ Tanker om å slutte } \\
\hline Opplevelse av støtte fra organisasjonen & $-0,08$ & IS & \\
\hline Opplevelse av tilknytning til organisasjonen & $-0,19$ & 0,00 & \\
\hline Opplevelse av kollektiv innovasjon & $-0,08$ & IS & \\
\hline Deltakelse i samarbeidsaktiviteter & $-0,04$ & IS & \\
\hline Opplevelse av tillit til rektor & $-0,03$ & IS & $8 \%$ \\
\hline
\end{tabular}

Note: IS = Ikke signifikant. Modell tilpasning: $x^{2}(284 d f)=530, p=0,00 ;$ RMSEA =0,04; CFI =0,94; SRMR = 0,06 .

\section{Oppsummering og konklusjon}

I denne studien har vi undersøkt nyutdannede læreres opplevelser av læreryrket. Mer spesifikt har vi studert hvilke faktorer som predikerer nyutdannede læreres opplevelse av jobbtilfredshet, stress og tanker om å slutte i jobben. Innledningsvis undersøkte vi noen gruppeforskjeller. Når det gjelder kjønnsforskjeller, støtter resultatene tidligere forskning som rapporterer at kvinner er mer tilfredse med arbeidsplassen, men at kvinner samtidig opplever mer stress enn menn (Klassen \& Chiu, 2010).

Når vi sammenligner nyutdannede med mer erfarne kolleger, viser våre funn at de nyutdannede generelt er mer tilfreds med yrket enn sine mer erfarne kolleger, noe som også er rapportert i TALIS 2013 (OECD, 2014). I tillegg har de nyutdannede også færre tanker om å slutte. Disse resultatene står i motsetning til litteraturens beskrivelser av nyutdannedes opplevelse av et "praksissjokk», noe som ytterligere underbygges av at det ikke er noen forskjeller mellom gruppene i opplevd stress (Fisher, 2011). I kontrast til praksissjokk-argumentet, kan resultatene i denne studien tyde på 
en trend der nyutdannede generelt er mer tilfreds med yrket enn de mer erfarne lærerne. Denne forskjellen kan selvfølgelig skyldes at nyutdannede generelt er mer entusiastiske enn lærerne som har vært mange år i skolen. Likevel er det en forskjell som det er verdt å legge merke til, da lærere ofte er blitt behandlet som en homogen gruppe både når det gjelder forskning og reformer i skolen. I løpet av de siste årene har det for eksempel blitt iverksatt flere satsninger (f.eks. «Ungdomstrinn i utvikling» og «Lærerløftet») for å styrke læreres kompetanse i sentrale undervisningsfag. Vi kan ikke på basis av disse resultatene si noe om hvordan disse satsningene har påvirket de erfarne lærernes jobbtilfredshet, men studien gir implikasjoner om at arbeidserfaring i skolen er en faktor som bør tas i betraktning når en utvikler tiltak for lærere. Relatert til dette er en implikasjon fra studien at vi trenger mer kunnskap om hva som påvirker erfarne læreres jobbmotivasjon og tilfredshet.

Våre resultater viser at de nyutdannede som hadde læreryrket som førstevalg var mer fornøyd med profesjonen og hadde færre tanker om å slutte. Videre viser resultatene at de som hadde en altruistisk motivasjon for å velge læreryrket rapporterte høyere tilfredshet med både skolen de jobbet på og læreryrket som profesjon. Dette korresponderer med tidligere forskning som har funnet sammenhenger mellom læreres indre og ytre motivasjon for å bli lærer, deres jobbtilfredshet og hvor lenge de blir i profesjonen (Ainley \& Carstens, 2018; Brandmo \& Nesje, 2017; Watt et al., 2012). I tillegg fant vi en svak sammenheng mellom opplevelse av å ha egenskaper til en god lærer og tilfredshet med læreryrket. Ikke overraskende indikerer resultatene at motivasjon for yrkesvalg har en betydning for hvor tilfreds en blir med yrket. Motivasjon for å bidra til samfunnet ser i denne studien ut til å være den viktigste.

Når det gjelder nyutdannede læreres egen kompetanse, viser resultatene at mestring av klasseledelse predikerer signifikant høyere tilfredshet med skolen de jobber på og lavere opplevelse av stress (Collie et al., 2012; McCarthy et al., 2015). Dette resultatet gir implikasjoner om at klasseledelse er en viktig ferdighet som bør vektlegges i lærerutdanning, og at satsningen som mange skoler har hatt med hensyn til å utvikle god klasseledelse er viktig.

I vår studie var det bare 26 \% av nyutdannede lærerne som oppga at de hadde en formell mentor, og majoriteten av disse mentorene var knyttet 
til lærerne med ett års erfaring eller mindre. Videre viser resultatene at det å ha en mentor ikke hadde noen sammenheng med jobbtilfredshet eller opplevelse av stress. Disse resultatene noe overraskende, gitt fokuset det har vært på veiledning av nyutdannede de siste årene. Det finnes flere mulige forklaringer på dette, for eksempel at veiledningen ikke er tilstrekkelig rettet inn mot faktorer som påvirker jobbtilfredshet og stress, eller at kvaliteten på veiledningen ikke er god nok.

Med hensyn til organisatoriske faktorer, så viser funnene at tilknytning til skolen, støtte fra organisasjonen og opplevelse av kollektiv innovasjon predikerer signifikant høyere tilfredshet med arbeidsplassen. Med andre ord, det å være følelsesmessig tilknyttet til skolen, det å få hjelp hvis man trenger det, og det at skolen oppleves som åpen for nye ideer ser ut til å gi høyere tilfredshet for de nyutdannede (Tiplic et al., 2015). I tillegg er opplevelsen av tilknytning til organisasjonen en signifikant prediktor for tilfredshet med yrket og tanker om å slutte. Mulige implikasjoner av funnene er at nyutdannede bør møtes med åpenhet og støtte, og at integrering i arbeidsmiljøet er viktig for deres trivsel og motivasjon.

\section{Referanser}

Ainley, J. \& Carstens, R. (2018). Teaching and learning international survey (TALIS) 2018 conceptual framework (OECD Education Working Papers, No. 187). OECD Publishing. https://doi.org/10.1787/19939019

Arnup, J. \& Bowles, T. (2016). Should I stay or should I go? Resilience as a protective factor for teachers' intention to leave the teaching profession. Australian Journal of Education, 6o(3), 229-244. https://doi.org/10.1177/0004944116667620

Bandura, A. (1986). Social foundations of thought and action: A social cognitive theory. Prentice-Hall.

Brandmo, C. \& Nesje, K. (2017). Factors motivating students to become secondary school teachers: Evidence from Norway. I H. M. G. Watt, P. W. Richardson \& K. Smith (Red.), Global perspectives on teacher motivation (s. 95-125). Cambridge University Press. https://doi.org/10.1017/9781316225202.004

Bryk, A. S., Sebring, P., Allensworth, E., Luppescu, S. \& Easton, J. (2010). Organizing schools for improvement: Lessons from Chicago. University of Chicago Press.

Caspersen, J. \& Raaen, F. D. (2014). Novice teachers and how they cope. Teachers and Teaching, 2o(2), 189-211. https://doi.org/10.1080/13540602.2013.848570 
Collie, R. J., Shapka, J. D. \& Perry, N. E. (2012). School climate and socialemotional learning: Predicting teacher stress, job satisfaction, and teaching efficacy. Journal of Educational Psychology, 104(4), 1189-1204. https://doi. org/10.1037/aoo29356

Fisher, M. H. (2011). Factors influencing stress, burnout, and retention of secondary teachers. Current Issues in Education, 14(1). https://cie.asu.edu/ojs/index.php/ cieatasu/article/view/658https://cie.asu.edu

Gjefsen, H. M., Gunnes, T. \& Stølen, N. M. (2014). Framskrivinger av befolkning og arbeidsstyrke etter utdanning med alternative forutsetninger for innvandring (SSB-rapport 2014/31). Statistisk sentralbyrå. https://www.ssb.no/arbeid-og-lonn/ artikler-og-publikasjoner/_attachment/20099o?_ts=14909943420

Klassen, R. M. \& Chiu, M. M. (2010). Effects on teachers' self-efficacy and job satisfaction: Teacher gender, years of experience, and job stress. Journal of Educational Psychology, 102(3), 741-756. https://doi.org/10.1037/aoo19237

Kyriacou, C. (1987). Teacher stress and burnout: An international review. Educational Research, 29(2), 146-152. https://doi.org/10.1080/0013188870290207

Law, K. S. \& Wong, C.-S. (1999). Multidimensional constructs M structural equation analysis: An illustration using the job perception and job satisfaction constructs. Journal of Management, 25(2), 143-16o. https://doi. org/10.1177/014920639902500202h

Mathieu, J. E., Hofmann, D. A. \& Farr, J. L. (1993). Job perception-job satisfaction relations: An empirical comparison of three competing theories. Organizational Behavior and Human Decision Processes, 56(3), 370-387. https://doi.org/10.1006/ obhd.1993.106oh

McCarthy, C. J., Lineback, S. \& Reiser, J. (2015). Teacher stress, emotion, and classroom management. I E. Emmer \& E. J. Sabornie (Red.), Handbook of classroom management (s. 301-321). Routledge. https://doi. org/10.4324/9780203074114

Miller, J. G. \& Wheeler, K. G. (1992). Unraveling the mysteries of gender differences in intentions to leave the organization. Journal of Organizational Behavior, 13(5), 465-478. https://doi.org/10.1002/job.4030130504

OECD. (2014). Talis 2013 results. An international perspective on teaching and learning. OECD publishing. https://doi.org/10.1787/23129638

OECD. (2005). Teachers matter: Attracting, developing and retaining effective teachers, education and training policy. OECD Publishing. http://dx.doi. org/10.1787/9789264018044-en

Roness, D. (2011). Still motivated? The motivation for teaching during the second year in the profession. Teaching and Teacher Education, 27(3), 628-638. https:// doi.org/10.1016/j.tate.2010.10.016 
Skaalvik, E. M., \& Skaalvik, S. (2007). Dimensions of teacher self-efficacy and relations with Strain factors, perceived collective teacher efficacy, and teacher burnout. Journal of Educational Psychology, 99(3), 611-625.

Skaalvik, E. M. \& Skaalvik, S. (2010). Teacher self-efficacy and teacher burnout: A study of relations. Teaching and Teacher Education, 26(4), 1059-1069. https://doi. org/10.1016/j.tate.2009.11.001

Skaalvik, E. M. \& Skaalvik, S. (2011). Teacher job satisfaction and motivation to leave the teaching profession: Relations with school context, feeling of belonging, and emotional exhaustion. Teaching and Teacher Education, 27(6), 1029-1038. https:// doi.org/10.1016/j.tate.2011.04.001

Skaalvik, E. M., \& Skaalvik, S. (2016). Teacher stress and teacher self-efficacy as predictors of engagement, emotional exhaustion, and motivation to leave the teaching profession, Creative Education, 7(13) 1785-1799. https://doi.org/10.4236/ ce.2016.713182

Skaalvik, E. M. \& Skaalvik, S. (2017). Motivated for teaching? Associations with school goal structure, teacher self-efficacy, job satisfaction and emotional exhaustion. Teaching and Teacher Education, 67, 152-16o. https://doi.org/10.1016/j. tate.2017.06.006

Tiplic, D., Brandmo, C. \& Elstad, E. (2015). Antecedents of Norwegian beginning teachers' turnover intentions. Cambridge Journal of Education, 45(4), 451-474. https://doi.org/10.1080/0305764X.2014.987642

Tiplic, D., Lejonberg, E. \& Elstad, E. (2016). Antecedents of newly qualified teachers' turnover intentions: Evidence from Sweden. International Journal of Learning, Teaching and Educational Research, 15(5), 103-127. http://ijlter.org/index.php/ ijlter/article/view/615/pdf

Veenman, S. (1984). Perceived problems of beginning teachers. Review of Educational Research, 54(2), 143-178. https://doi.org/10.2307/1170301

Watt, H. M. G., Richardson, P. W., Klusmann, U., Kunter, M., Beyer, B., Trautwein, U. \& Baumert, J. (2012). Motivations for choosing teaching as a career: An international comparison using the FIT-Choice scale. Teaching and Teacher Education, 28(6), 791-805. https://doi.org/10.1016/j.tate.2012.03.003

Weiss, E. M. (1999). Perceived workplace conditions and first-year teachers' morale, career choice commitment, and planned retention: A secondary analysis. Teaching and Teacher Education, 15(8), 861-879. https://doi.org/10.1016/So742051X(99)00040-2 


\title{
KAPITTEL 7
}

\section{Læringsfremmende vurderingspraksis på ungdomstrinnet: Funn fra TALIS 2018 og LISA-prosjektet}

\section{Tone Cecilie Carlsten}

Nordisk institutt for studier av innovasjon, forskning og utdanning (NIFU)

\section{Inger Throndsen \& Kirsti Klette}

Institutt for læreritdanning og skoleforskning, Universitetet i Oslo

\begin{abstract}
Assessment practices promoting learning at the lower secondary level: Findings from TALIS 2018 and the LISA project

This chapter presents some of the results from the Norwegian TALIS 2018 survey related to professional knowledge, competence, and practice. Findings from teachers' reporting on their own teaching practices are highlighted, specifically the part of their teaching that deals with assessment practices. Results from the TALIS survey are then interpreted in light of the results from a research project that deals with the same topic with other data sources.

The Linking Instruction and Student Achievement project (LISA) combines video data from teaching practices in language arts and mathematics at the lower secondary level with test results from national tests (reading and arithmetic) from the same classes from which the observation data were taken. LISA is the largest video study of its kind of classroom practices in the Nordic countries and is a suitable frame of interpretation for TALIS 2018 data, as all data materials are linked to the last period of the former national curriculum in Norway. Findings from TALIS 2018 show that there could have been far more teachers who checked that the feedback they provide on written assignments is understood by their students. Results from the LISA project confirms this finding and also show that quite a few teachers are responsible for a large part of the feedback that is regarded to be of high quality. The chapter indicates that there is great potential for working more collectively on
\end{abstract}

Sitering av denne artikkelen: Carlsten, T. C., Throndsen, I. \& Klette, K. (2021). Læringsfremmende vurderingspraksis på ungdomstrinnet: Funn fra TALIS 2018 og LISA-prosjektet. I J. K. Björnsson (Red.), Hva kan vi loere av TALIS 2018? Gode relasjoner som grunnlag for loering (Kap. 7, s. 123-141). Cappelen Damm Akademisk. https://doi.org/10.23865/noasp.123.ch7

Lisens: CC BY-NC-ND 4.O. 
this topic both in the teacher education stage and as part of a well-managed lifelong learning system for teachers.

Keywords: professional learning, assessment practices, classroom studies, video studies

\section{Introduksjon}

Resultatene fra TALIS 2018 er, som vi så i kapittel 1, delt inn i fem hovedområder. I dette kapittelet skal vi gå nærmere inn på resultater som hører hjemme under område 1: profesjonskunnskap, kompetanse og praksis. Vi skal spesielt se på læreres rapportering om egen undervisningspraksis, nærmere bestemt den delen av deres undervisning som handler om vurderingspraksis.

Noen av hovedfunnene om læreres vurderingspraksiser er tidligere presentert i den norske kortrapporten TALIS 2018 - Første hovedfunn fra ungdomstrinnet (Throndsen et al., 2019). I dette kapittelet skal vi trekke fram noen eksempler når det gjelder å se på TALIS 2018-data om læringsfremmende vurderingspraksis. Vi skal dessuten se på hvordan funn fra TALIS-undersøkelsen kan tolkes i lys av resultater fra et forskningsprosjekt som behandler samme tema med andre datakilder. Til dette formålet har vi valgt å ta utgangspunkt i LISA, et forskningsprosjekt som kombinerer videodata fra undervisning i norsk og matematikk på ungdomstrinnet med testresultater fra framgang på nasjonale prøver (lesing og regning) fra de samme klassene som observasjonsdataene er hentet fra. LISA er et akronym for Linking Instruction and Student Achievement,${ }^{1}$ og er den største videostudien på skole i sitt slag fra de nordiske land. Den gir dermed et unikt innblikk i hvordan det undervises i norske klasserom på ungdomstrinnet (Klette et al., 2017). Prosjektet er et godt supplement til å tolke data fra TALIS 2018, ettersom begge datainnsamlinger er knyttet til undervisning etter læreplanene i siste periode av Kunnskapsløftet.

Som nevnt i kapittel 1 og 5 la vi til noen nasjonale tilleggsspørsmål i TALIS 2018. Noen av disse var utarbeidet i samarbeid med prosjektleder av

1 https://www.uv.uio.no/ils/forskning/prosjekter/lisa/ 
LISA-studien, og handlet om læreres læringsfremmende vurderingspraksis. Målet med samarbeidet var å styrke spørsmålsstillinger som kunne utdype tidligere hovedfunn fra TALIS $2008 \mathrm{og}$ TALIS 2013. TALIS-funn fra 2008 viste at det var en relativt svakt utviklet faglig oppfølgingskultur fra lærer til elev (Vibe et al., 2009). I analyser av datamaterialet fra 2013 kunne vi se antydninger til at dette forholdet var noe forbedret (Caspersen et al., 2014). Litt av utfordringen med sammenligningene før TALIS 2018 var at spørsmålene var endret mellom 2008 og 2013, og at de i liten grad var presise nok for å tolkes i lys av forskning på vurderingspraksis i den norske konteksten. I dette kapittelet skal vi derfor se nærmere både på hovedfunn og funn fra de nasjonale tilleggsspørsmålene, og tolke dem opp mot noen hovedfunn fra LISA-prosjektet. I LISA er det samlet inn data fra undervisning i matematikk- og norskfaget. For dette kapittelet har vi derfor valgt å bruke utvalgte data for vurdering og tilbakemelding i norsk og matematikk også fra TALIS.

Forskningsspørsmålet vårt er: Hvilken hyppighet og kvalitet er det $p a ̊$ tilbakemeldinger til elever på ungdomstrinnet i norsk-og matematikkfaget ifølge TALIS 2018-data og LISA-data, og hvordan kan disse studiene komplementere hverandre for å gi bedre forståelse for hva som kjennetegner loeringsfremmende vurderingspraksis i Norge?

Kapittelet gir først en begrepsavklaring og en kort status for norsk policyutvikling knyttet til læreres vurderingspraksis. Deretter presenteres mål og utvalgte funn fra TALIS 2018-undersøkelsen for dette temaet for norsk- og matematikkfaget, før vi sammenholder dette med mål og noen relevante resultater fra LISA-studien. Til slutt oppsummerer vi hva disse funnene sier om kvaliteten på fortløpende tilbakemeldinger, og hvordan ulike datakilder kan utfylle hverandre når det gjelder å gi skoleledere, lærere og lærerstudenter kunnskap om hva som kjennetegner god vurderingspraksis på ungdomstrinnet.

\section{Rammer for vurderingspraksis i norsk skole}

Vi starter denne delen med en begrepsavklaring. I vurderingssammenheng har det tradisjonelt vært skilt mellom formativ og summativ vurdering. Mens det første er en vurderingsform som har som mål å fremme 
læring, skiller den seg fra summativ eller avsluttende vurdering som har som mål å bedømme eller rangere læringsresultater (Scriven, 1967). Senere har forskere ønsket å erstatte begrepet formativ med læringsfremmende, fordi dette på en bedre måte viser til fortløpende praksiser som ikke anses som «mini-summative». Det vil si at hensikten er å vektlegge pedagogiske aspekter ved tilbakemelding til elever som også ligger innenfor deres juridiske rett til medvirkning i vurderingsarbeidet. Dette blir i norsk sammenheng også kalt underveisvurdering. Det handler altså ikke om at lærere skal samle dokumentasjon for framtidig karaktersetting, slik det «mini-summative» også har blitt kritisert for i kjent internasjonal forskning på tilbakemelding i klasserommet (jf. Black \& Wiliam, 1998; Hattie \& Timperley, 2007; Wiliam, 2010).

I dette kapittelet bruker vi begrepet læringsfremmende vurderingspraksis om den systematiske delen av en lærers undervisning som dreier seg om å gi tilbakemeldinger som har som mål å fremme elevers læring. Vi gjør dette for å understreke at begrepet underveisvurdering, slik det ofte brukes i policysammenheng, nylig har fått et tillegg til læringsfremmende vurdering i fag: i henhold til forskrift til opplæringslova (2006) er nå også lærelyst tatt inn i formålet med vurdering i fag (Forskrift til opplæringslova, kap. 3, 2020). Dette var ikke en del av forskriften på det tidspunktet TALIS 2018 og LISA-prosjektet ble utviklet og gjennomført, men var likevel en del av det forskningsbaserte grunnlaget for prosjektene. Vi bruker også bevisst begrepet vurderingspraksis framfor vurderingskultur eller oppfølgingskultur, slik det ble gjort i rapporteringer fra TALIS 2008 og TALIS 2013. Dette gjør vi for her å fokusere lærernes egenrapporterte vurderingshandlinger i TALIS 2018. En internasjonal komparativ storskala-spørreundersøkelse som TALIS har heller ikke gode nok data til å si så mye om kvaliteten på det fysiske miljøet, menneskene som inngår i det og selve relasjonene dem imellom på en måte som er sammenlignbart med det man kan observere i data fra LISA-prosjektet.

Vi skal nå ramme inn hvordan vi forstår vurderingspraksis i norsk skole ved å gi en kort gjennomgang av noen sentrale endringer i policyfeltet de siste 15 år. I kapittel 5 skisserte vi hvordan rammene for skoleutvikling på ungdomstrinnet har blitt tydeliggjort i policysammenheng spesielt de siste 8 årene (Carlsten, 2021). I sammenheng med vurderingsfeltet sett $\mathrm{i}$ 
lys av skoleutvikling kan vi gå litt lenger tilbake; til St.meld. 16 (20062007) ... og ingen stod igjen. Tidlig innsats for livslang loering. Her ble utfordringene for elevvurdering oppsummert i fire punkter: 1) Regelverket for individvurdering oppfattes ikke klart nok; 2) både lærerutdanningen og skolen mangler tilstrekkelig kompetanse; 3) det er svak vurderingskultur og vurderingspraksis i skolen; 4) det er forsket lite på individvurdering i Norge. Dette gjaldt ikke bare ungdomstrinnet. Funn fra evalueringen av Reform 97 viste at vurderingspraksis på barnetrinnet blant annet bar preg av fravær av eksplisitte, klare faglige standarder (Klette, 2003). OECD/ CERI (2005) etterlyste også en mer systematisk oppfølging av elevers utvikling på ungdomstrinnet. Som en oppfølging av St.meld. 16 (20062007) etablerte Utdanningsdirektoratet prosjektet Bedre vurderingspraksis i 2007. Sluttrapporten fra forskerne som evaluerte prosjektet anbefalte en videreføring for å styrke vurderingskompetansen i grunnopplæringen (Throndsen et al., 2009). Høsten 2009 ble ny forskrift om individuell vurdering fastsatt, og disse ga et tydeligere læringsfokus i bestemmelsene om underveisvurdering. Det er altså denne forskriften som formelt lå til grunn i Norge da data ble samlet inn i TALIS 2018 og i LISA-prosjektet.

I stortingsmeldingen Motivasjon - Mestring - Muligheter ble det pekt på tiltak som burde settes i gang for å øke lærernes undervisningskompetanse og dermed kvaliteten på elevenes opplæring (Meld. St. 22 (20102011)). Ett av områdene som ble nevnt spesielt var elevvurdering. Det førte til den fireårige nasjonale satsingen Vurdering for loering (VFL) som ble etablert 2010 (Nasjonalt kompetansemiljø i vurdering, 2012). Satsingen VFL ble videreført fra 2014 til 2018, som en oppfølging av Meld. St. 20 (2012-2013) På rett vei. Den nasjonale satsingen på læringsfremmende vurdering gjaldt hele skolesektoren. I en rapport om VFL gjennomført som en del av Spørsmål til Skole-Norge våren 2017, ble det konkludert med at skoleledere og -eiere som hadde deltatt i satsingen ga uttrykk for et mer omfattende arbeid med vurderingspraksis enn de som ikke hadde deltatt (Larsen et al., 2017). I Utdanningsdirektoratets egen rapportering om erfaringer fra satsingen, basert på flere kilder, framkommer det at det fortsatt er områder som er utfordrende når det gjelder å styrke læringsfremmende vurdering. Ikke minst pekes det på faren ved at vurderingspraksis forenkles og reduseres til «et sett av innøvde prosedyrer og 
mekaniske teknikker uten at dette bidrar til reflektert praksis og læring» (Utdanningsdirektoratet, 2019). Dermed vises det til et behov for at lærere har god kjennskap til forskning og grunntanker som ligger til grunn for læringsfremmende vurdering, slik dette kapittelet gir noen eksempler på.

Den nye overordnede delen av læreplanverket fagfornyelsen understreker også betydningen av læringsfremmende vurderingspraksis (Kunnskapsdepartementet, 2017). Blant annet er det en viktig intensjon i oppfølgingen av Meld. St. 28 (2015-2016) Fag - Fordypning - Forståelse - En fornyelse av Kunnskapsløftet at læreplanene skal legge til rette for dybdelæring. For å relatere dette til vårt forskningsspørsmål, så vil dermed hyppighet og kvalitet på loereres tilbakemeldinger handle om fortløpende tilbakemeldinger som er basert på en balanse mellom forskningsbasert og skjønnsbasert vurderingskompetanse i møte med elevers aktive rolle i læringsprosessen - på en måte som styrker reflekterte sider av praksis og læring også for lærere. En læringsfremmende vurderingspraksis vil i utvidet forstand også handle om å koble det systematiske arbeidet med vurdering for læring bedre til læreplanarbeid som en del av skoleutvikling.

Selv om våre TALIS-data som tidligere nevnt både er begrenset til hyppighet av vurderingshandlinger og en tidsramme som ligger forut for høsten 2020, da det nye læreplanverket trådte i kraft, er dette elementer som nasjonal og internasjonal litteratur innen klasseromsforskning og forskning på lærerprofesjonalitet lenge har pekt på som forutsetninger for god undervisningspraksis i skolen (se f.eks. Ball \& Cohen, 1999; Grossman \& Loeb, 2010; Grossman \& McDonald, 2008; Hattie, 2009; Hiebert et al., 2002; Hiebert \& Stiegler 2000; Klette, 2018; Klette et al., 2017; Seidel \& Shavelson, 2007; Timperley \& Alton-Lee, 2008). Vi skal derfor trekke noen linjer mellom våre funn og gi noen implikasjoner for god læringsfremmende vurderingspraksis helt til slutt i dette kapittelet. Først skal vi imidlertid se nærmere på hva TALIS 2018- og LISA-analysene viser oss om læringsfremmende vurderingspraksis på ungdomstrinnet i Norge.

\section{Læreres vurderingspraksis i TALIS 2018}

Når det gjelder mål og metode for TALIS-studien viser vi til kapittel 1, og går her inn på funn som er relevante for dette kapittelet. For å få 
kunnskap om vurderingsformene som lærerne på ungdomstrinnet benytter i undervisningen, ble de i TALIS 2018 bedt om å besvare følgende spørsmål: Hvor ofte bruker du følgende metoder for å vurdere elevenes ferdigheter? Her skulle lærerne ta utgangspunkt i elevvurderingen sin i en nærmere definert klasse. Tabell 1 viser andelen lærere som underviser i norsk (lesing, skriving og litteratur på morsmålet) og matematikk som svarer «ofte»/«alltid» på de ulike utsagnene om elevvurdering. De andre svaralternativene var «aldri eller nesten aldri» og «noen ganger».

Tabell 1 Prosentandelen lærere som underviser i norsk og matematikk i en aktuell klasse som svarer at de benytter ulike vurderingsformer «ofte»/«alltid».

\begin{tabular}{lcc}
\hline Utsagn & $\begin{array}{c}\text { «Ofte»/«Allid» } \\
\text { Norsk }\end{array}$ & $\begin{array}{c}\text { «Ofte»/«Altid» } \\
\text { Matematikk }\end{array}$ \\
\hline Jeg utvikler og gjennomfører egne prøver. & 79 & 70 \\
Jeg gir skriftlig tilbakemelding på elevenes & 93 & 77 \\
arbeid i tillegg til karakter. & & \\
Jeg lar elevene selv vurdere sin egen framgang. & 44 & 38 \\
Jeg observerer hvordan elevene jobber med & 73 & 56 \\
bestemte oppgaver og gir dem tilbakemelding. & & \\
\hline
\end{tabular}

Som tidligere nevnt, har det fra nasjonalt hold vært en langvarig satsing på å utvikle lærernes formative vurderingskompetanse. Faglige tilbakemeldinger anses som et viktig element i læringsfremmende vurdering. Som det går fram av tabell 1 svarer hele ni av ti lærere som underviser i norsk at de «ofte»/«alltid» gir skriftlig tilbakemelding på elevenes arbeider i tillegg til å sette karakter. Det er nesten åtte av ti lærere som underviser i matematikk som gjør det samme. Dette resultatet gjør at Norge er blant landene hvor en slik vurderingspraksis forekommer hyppigst (i alt 48 land deltok i TALIS 2018, inklusive alle de nordiske landene). Gode skriftlige tilbakemeldinger har en viktig funksjon ved at de kan gi elevene bedre innsikt i hvor de står faglig, og hva de bør vektlegge i det videre arbeidet med læringsstoffet (Hattie \& Timperley, 2007). Fortløpende vurdering av denne typen vil derfor kunne fungere som et redskap for videre læring. På tvers av alle fag var det $82 \%$ av norske lærere som svarte at de «ofte»/«alltid» ga slik tilbakemelding. I TALIS 2013 svarte $75 \%$ av de norske ungdomsskolelærerne at de ga elevene skriftlig tilbakemelding i tillegg til karakter. Det har således vært en positiv økning på dette området siden forrige runde av TALIS-undersøkelsen. 
Når det gjelder faglig feedback, svarer hele sju av ti lærere som underviser i norsk at de observerer hvordan elevene jobber med bestemte oppgaver og gir dem tilbakemelding på det de gjør (jf. tabell 1). Slik umiddelbar tilbakemelding kan være en viktig korreksjon eller pekepinn på om elevene er på «feil spor» i forhold til læringsmålet. $56 \%$ av lærerne som underviser i matematikk svarer at de gir slik fortløpende tilbakemelding, så her er det et forbedringspotensiale.

Tabellen viser også at omtrent fire av ti lærere involverer elevene i vurderingen, og at dette er ganske likt mellom norsk og matematikk. Tallet på tvers av fag lå i TALIS 2018 på 39 \% for norske lærere. I faglitteraturen blir selvvurdering sammen med tilbakemeldinger løftet fram som sentrale elementer i læringsfremmende vurdering (Black \& Wiliam, 2009). For at elever skal kunne nyttiggjøre seg de faglige tilbakemeldingene, er det imidlertid en forutsetning at de forstår hva som ligger i lærerens vurdering. Selvvurdering kan bidra til å fremme slik forståelse. Til sammenligning svarte $29 \%$ av lærerne at de lar elevene vurdere sin egen framgang i TALIS 2013. Det har altså vært en positiv endring på dette området også.

For å undersøke om lærerne er opptatte av å sjekke om tilbakemeldingene de gir på skriftlige oppgaver blir forstått av elevene, ble det i spørreskjemaet lagt til et nasjonalt spørsmål om nettopp dette. Følgende utsagn ble benyttet: Jeg sjekker at tilbakemeldinger jeg gir på skriftlige oppgaver blir forstått av elevene. Analyser viser at drøyt halvparten av lærerne $(53 \%)$ sjekker «ofte»/«alltid» at elevene forstår tilbakemeldingene som de får på tvers av alle fag. For lærere som underviser i norsk er tallet imidlertid så høyt som $74 \%$, mens det for lærere som underviser i matematikk er på $54 \%$. Selv om det er forskjell på oppgaveformer som gis i de to fagene, skulle lærerne her svare på grunnlag av de skriftlige oppgavene som faktisk gis. For at tilbakemeldinger skal være læringsfremmende, er det helt vesentlig at den enkelte elev forstår innholdet i tilbakemeldingen (Black \& Wiliam, 2009). På dette området ser det med andre ord ut til at lærernes måter å gi slike tilbakemeldinger på har et forbedringspotensial, spesielt i matematikk.

Videre viser tabell 1 at syv av ti lærere utvikler og gjennomfører egne prøver. Faglige prøver har alltid hatt en sentral plass i undervisningen, og har i stor grad blitt assosiert med summativ vurdering (dvs. vurdering av 
læring). Prøver kan imidlertid brukes på en formativ måte (dvs. vurdering for læring) dersom resultatene brukes til å forbedre både lærerens undervisning og elevenes læring. Det avgjørende er med andre ord i hvilken grad elevenes svar på prøver bidrar til at læreren korrigerer og tilpasser undervisningen på bakgrunn av elevenes prestasjoner, samt at de blir brukt som grunnlag for tilbakemelding om hva elevene har forstått og hva de ikke har forstått. Det er dette som avgjør om bruken av prøver kan anses som formativ eller ikke. Ifølge sentrale forskere på området er vurderingen formativ dersom den fører til handlinger som fremmer elevenes læring med utgangspunkt i arbeidet deres (Harlen, 2007; Stobart, 2008).

Forskerorganisasjonen EARLI (European Association for Research on Learning and Instruction) har argumentert for viktigheten av at vurdering for læring integreres i lærernes klasseromsundervisning. Formativ vurdering dreier seg ikke om å benytte en bestemt metode, men læringsfremmende undervisning kjennetegnes ved følgende:

- Eksplisitte mål for undervisningen gjøres kjent for elevene, og kriterier illustrerer hvordan mål kan være om de er oppnådd.

- Loreren stiller «rike spørsmål» og gir elevene tid til å reflektere før det bes om et svar. Dette gjør at elevene bedre får vist hvor de er i læringsprosessen.

- Loereren gir tilbakemeldinger hvor formålet er å hjelpe elevene til å minske gapet mellom det de kan og det de forsøker å strekke seg etter. Tilbakemeldingene skal gi elevene kunnskap om hvordan de skal kunne komme seg til det ønskede læringsmålet.

- Vurdering av seg selv og andre bidrar til å øke elevenes forståelse av eget og andres arbeid, særlig når det gjelder kvalitet. Elever som utvikler kunnskap på dette feltet, øker sin bevissthet om egen læring.

TALIS 2018 inneholdt også spørsmål om kjennetegn ved god undervisning, og noen av spørsmålene er relevante i forhold til punktene overfor som dreier seg om karakteriske trekk ved formativ undervisningspraksis. Tabell 2 viser andelen lærere som underviser i norsk (lesing, skriving og litteratur på morsmålet) og matematikk som svarer «ofte»/«alltid» på 
spørsmålet «Tenk på undervisningen din, hvor ofte gjør du følgende?» hvor utsagnene går på å sette seg mål og å stille spørsmål til elevene. De andre svaralternativene var «aldri eller nesten aldri» og «av og til».

Tabell 2 Prosentandelen lærere som underviser i norsk og matematikk i en aktuell klasse som svarer «ofte»/«alltid» på utsagn om sin undervisningspraksis

\begin{tabular}{lcc}
\hline Utsagn & $\begin{array}{c}\text { «Ofte»/«Alltid» } \\
\text { Norsk }\end{array}$ & $\begin{array}{c}\text { «Ofte»/«Alltid» } \\
\text { Matematikk }\end{array}$ \\
\hline Jeg starter timen med å presentere klare mål for timen. & 77 & 73 \\
Jeg forklarer hva jeg forventer at elevene skal lære. & 87 & 86 \\
Jeg presenterer oppgaver hvor det ikke er en opplagt & 66 & 41 \\
løsning. & 49 & 60 \\
Jeg oppfordrer elevene til å velge egne måter å løse & & \\
komplekse oppgaver på. & & \\
\hline
\end{tabular}

Tabell 2 viser at undervisningstimer i norsk og matematikk har noenlunde lik struktur ved at de har forholdsvis mange eksplisitte mål som framstilles for elevene. Det er en noe ujevn balanse mellom lærerens eksplisitte undervisningsformer og mulighetene som gis elever til selv å bidra i former som er ment å mer eksplisitt styrke dybdelæring.

Som det går fram av denne presentasjonen av TALIS-data, så gir ikke TALIS-undersøkelsen informasjon om kvaliteten i lærernes tilbakemeldinger. Selv om en slik survey er begrenset til å si noe om hyppighet av tilbakemeldinger, så ser vi at valg av spørsmål likevel har en sammenheng med forskning på karakteristiske trekk ved god formativ vurderingspraksis. Funnene viser at det er en del likheter mellom norsk og matematikk når det gjelder spesielt den delen av undervisningspraksis som legger grunnlaget for eksplisitt struktur. Vi finner også at det er en lavere andel lærere som inkluderer former for tilbakemeldinger som trekker inn elevene i vurderingsarbeidet og gir grunnlag for dybdelæring. Som det ble pekt på i Utdanningsdirektoratets rapportering om erfaringer fra satsingen Vurdering for loering, er dette områder som er utfordrende når det gjelder å styrke læringsfremmende vurdering. Ikke minst ble det pekt på faren ved at vurderingspraksis forenkles og reduseres til «et sett av innøvde prosedyrer og mekaniske teknikker uten at dette bidrar til reflektert praksis og læring» (Utdanningsdirektoratet, 2019). Former for tilbakemeldinger som gir slik kvalitet handler altså om det vi har vært inne på 
i analysen over, som handler mer om den løpende muntlige tilbakemeldingen mellom lærere og elever i selve undervisningen. LISA-prosjektet er designet nettopp med hensikt å finne ut mer om hva som kjennetegner og gir kvalitet i slik praksis, noe vi skal komme inn på i neste avsnitt.

\section{Hvordan vurderes læreres tilbakemeldinger i LISA-prosjektet?}

Før vi trekker fram hovedfunn om læreres undervisningspraksis fra LISA-prosjektet som gir innsikt i hva som kjennetegner kvalitet i læringsfremmende tilbakemeldinger, vil vi kort gi en beskrivelse av designet. Prosjektet ble startet opp ved Institutt for lærerutdanning og skoleforskning ved Universitetet i Oslo i 2013, som et fireårig grunnforskningsprosjekt finansiert av Norges forskningsråd. Utgangspunktet for studien var tredelt: For det første var det et mål å forstå hvordan undervisningspraksis hang sammen med elevenes læring i matematikk og norskfaget målt via framgang på nasjonale prøver i lesing og regning. For det andre var det et ønske om å utvikle et forskningsdesign som kunne binde sammen klasseromsdata med data fra elevresultater (her: framgang på nasjonale prøver) i en integrert modell. For det tredje lå det til grunn en intensjon om å teste ut standardiserte kodingsmanualer og instrumenter som kunne måle kvalitet på undervisning i en norsk kontekst. Ved å teste ut og videreutvikle robuste og internasjonale instrumenter komparativt, kunne dette bidra med nye metoder for å få informasjon om lærernes undervisning på tvers av klasserom og kontekster og gi oppdatert kunnskap om dette relevant for både lærerutdanningen og $\mathrm{i}$ etter- og videreutdanning av lærere. I dette kapittelet skal vi trekke fram funn som handler om læreres tilbakemeldinger i norsk og matematikk som et eksempel, og ser dermed ikke direkte på elevenes prestasjoner i denne sammenheng.

I LISA-prosjektet har forskerne gjort videoopptak av fire påløpende undervisningstimer i norsk og matematikk på 8. trinn ved tilnærmet 50 ungdomsskoler i Norge ( $\mathrm{n}=47$ i matematikk og norsk, totalt 94 klasserom). Ett kamera filmet klassen som helhet og ett kamera har fulgt læreren. En grunn til at videodata er foretrukket framfor klasseromsobservasjoner 
innhentet på stedet er at det er en mer presis og dermed systematisk måte å innhente data, der det også er mulig å tydelig skille mellom datainnhenting og datatolkning. Videre kan dataene analysere fra ulike vinkler og perspektiver samt at flere forskere har mulighet til å analysere samme datamateriale - inkludert å diskutere mulige tolkninger. Videre ble det innhentet data om de observerte lærerne, så som utdanningsbakgrunn, faglig skolering i undervisningsfaget og yrkeserfaring. Elevene har også svart på en spørreundersøkelse, og forskerne har vurdert observasjonsdata opp mot elevenes spørreskjemadata og de samme elevenes framgang på nasjonale prøver i henholdsvis lesing og regning.

I LISA-prosjektet blir videodata fra klasserom på ungdomstrinnet analysert med en kodemanual som kalles PLATO (Grossman et al., 2013). Dette er et akronym for The Protocol for Language Arts Teaching Observation. Kodemanualen er utarbeidet av forskere ved Stanford University, og man må være sertifisert for å kunne bruke denne. Grunnen er at de som observerer kan kalibrere og styrke sine tolkninger basert på en felles forskningsbasert og validert forståelse av hva undervisningsaktiviteter som lærernes bruk av tilbakemeldinger, strategiundervisning og tilsvarende innebærer. PLATO-manualen har blitt oversatt til norsk og justert til en norsk kontekst. Den er egnet for å analysere mange viktige sider ved undervisning og vurdering, men adresserer ikke helheten i en skolekultur, slik som emosjonelle aspekter eller lærerens planlegging og refleksjoner tilknyttet faglig arbeid utenfor klasserommet. Den er imidlertid godt egnet for å analysere læringsfremmende vurderingshandlinger både i norsk og andre fag i justert format.

PLATO består av fire hovedområder: 1) undervisningsmessig støtte (scaffolding); 2) faglige krav; 3) bruk og representasjon av fagstoff; 4) klasseromsmiljøet. Disse områdene er igjen delt inn i 12 elementer som skåres av observatører på en skala fra 1-4. I PLATO-manualen er tilbakemelding et element innenfor området «undervisningsmessig støtte». I analysene fokuseres kvaliteten på tilbakemeldinger og især hvordan læreres (og elevers) tilbakemeldinger kan bistå elevene i deres videre arbeid. Tilbakemelding i denne sammenheng handler altså om hvordan læreren kommenterer kvaliteten på elevenes arbeider, og ikke minst på hvordan de blir veiledet videre for å heve kvaliteten på sitt eget arbeid. 
I kodemanualen er gode tilbakemeldinger (score 3 og 4) karakterisert ved at de er spesifikke og fagrettede, og at de bidrar til at elevene forstår hvordan de kan forbedre konkrete sider ved eget arbeid / de ulike aktiviteter. Fravær av tilbakemeldinger og tilbakemeldinger som er generelle og vage gis respektive score 1 og score 2. Score 2-tilbakemeldinger er for eksempel karakterisert ved at de er lite forankret i elevenes konkrete arbeid og der forslag til forbedringer er mer preget av å være innrettet mot selve aktiviteten enn mot hvilke ferdigheter eller kunnskap elevene har og trenger.

Observasjonskodene som benyttes i LISA-prosjektet bygger på forskningsbasert fagdidaktisk kunnskap om undervisning innen hvert av de aktuelle fagområdene (language arts/mathematics), og oppdatert generell litteratur på hva som kjennetegner undervisning av høy kvalitet i klasserom. Kodemanualene er kontinuerlig i en prosess av forskningsbasert utvikling og faglig oppdatering basert på analyser av hundrevis av eksempler på diverse læreres undervisning både i USA og nordiske land. ${ }^{2}$ Likevel er manualene såpass integrert $\mathrm{i}$ et internasjonalt fagfellesskap (derav også kravet om sertifisering for å bruke dem) at justeringer ikke skal skje på en slik måte at det går ut over kvalitet og internasjonale komparative dimensjoner.

Hva kan LISA-prosjektet gjennom denne metoden si oss om kvalitet på læreres tilbakemeldinger i klasserommet? Ser vi på tvers av de 95 observerte klasserommene (48 i matematikk og 47 i norsk) er især to trekk framtredende: Gjennomgående gis det relativt mye og hyppige tilbakemeldinger i disse klasserommene. Hovedvekten av disse tilbakemeldinger er imidlertid hva vi karakteriserte som score 2; det vil si vage, generelle (og ofte positive) tilbakemeldinger. Typiske tilbakemeldinger av denne typen er «Bra, dere!», «Riktig», «Ikke helt», «Kanskje du kan spørre hva læringspartneren din mener?», «Hva med noen flere detaljer?» eller «Her skulle det være avsnitt». Som vi ser av figur 1 forekommer denne type tilbakemeldinger i de fleste observerte klasserom og i begge fag.

2 https://www.uv.uio.no/quint/english/about/ 


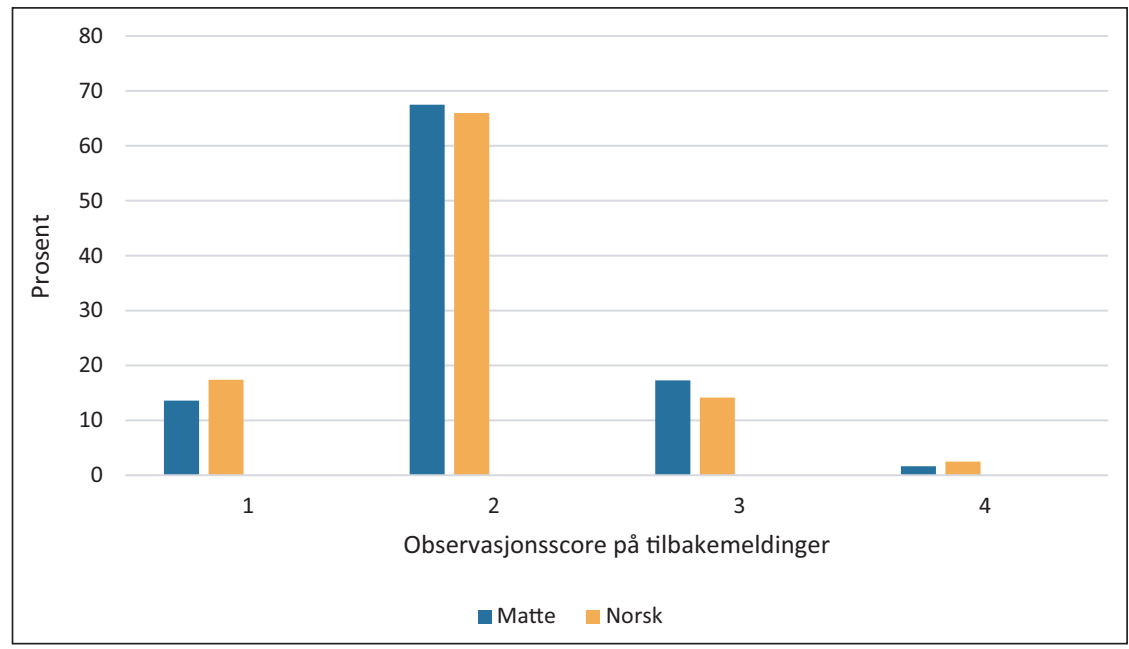

Figur 1 Læreres tilbakemeldinger til elever i matematikk og norsk i observerte klasserom på ungdomstrinnet i Norge i LISA-prosjektet.

Tilnærmet $70 \%$ av de observerte tilbakemeldingene er hva vi betegner som generelle, overflatiske og hva vi også vil karakterisere som prosedurale (hvordan løse en oppgave). De gir liten anvisning for hvordan eleven kan jobbe videre for å forbedre eget arbeid. Under $5 \%$ av observasjonene har blitt rubrisert som høykvalitets-tilbakemeldinger. Det vil si tilbakemeldinger som er konkrete, spesifikke og gir anvisninger for hvordan elevene kan bruke lærerens tilbakemelding for å forbedre eget arbeid.

Av de 95 observerte lærerne i LISA-prosjektet var det 9 lærere (fem i norsk og fire i matematikk) som var ansvarlige for alle tilbakemeldinger med høye scorer (score 4). Dette er et interessant funn. Det peker mot at de som har et repertoar for hvordan de kan gi konkrete tilbakemeldinger bruker det - og at de bruker det konsistent. Nærstudier av de fem lærerne som fikk score 4 i norsk viste for eksempel at disse fem ga høykvalitetstilbakemeldinger på mange og høyst ulike måter. Det som var felles, var at de brukte dem konsistent og på tvers av situasjoner, og at de ofte kombinerte de konkrete og spesifikke tilbakemeldingene (score 4) med mer vage og generelle tilbakemeldinger (score 2) for å skape en skjønnsbasert balanse og flyt i kommunikasjonen med elevene (Dåsvatn, 2016).

Det er positivt at norske lærere på ungdomstrinnet gir oppmuntrende og generelle tilbakemeldinger. Det er imidlertid grunn til å være bekymret over at så få av de observerte lærerne hadde et repertoar hvor 
de kombinerte tilbakemeldinger som «Fint» og «Bra jobbet!» med spesifikke og konkrete tilbakemeldinger anvisninger som kunne hjelpe elvene i deres videre arbeid. Dette eksemplet viser derfor at det fremdeles er en vei å gå for at norske lærere kan legge bedre til rette for de målene som både policy og forskning peker på som god vurderingspraksis. Funnene fra LISA-prosjektet viser også at det fortsatt er et stykke arbeid som må gjøres før kvaliteten på tilbakemeldinger til elever for å fremme læring blir en del av skolenes arbeid med vurderingspraksis som del av en felles skoleutvikling.

\section{Konklusjon}

Vi startet dette kapittelet ved å sammenstille sider av læreres undervisningspraksis og vurderingspraksis. Vi har pekt på at disse to sidene ved læreres arbeid ikke alltid har blitt kategorisert på en integrert måte, men at det har skjedd en endring innen både policy- og forskningsfelt som har gått i retning av å se deler av vurderingsarbeidet som en kvalitet ved læreres undervisningspraksis.

Som nevnt har de nasjonale satsingene rundt vurderingsarbeid i skolen satt som mål å gjøre læringsfremmende vurderingspraksis til et systematisk arbeid som også knyttes bedre til læreplanarbeid som en del av en kollektiv skoleutvikling. Utdanningsdirektoratets rapportering om erfaringer fra satsingen Vurdering for loering understreker dette kollektive aspektet ved vurderingsarbeid. Ikke minst framheves det at mangel på forskningsbasert kunnskap om ulike sider av dette arbeidet kan føre til at vurderingspraksis forenkles og reduseres på instrumentelt vis, som i liten grad bidrar til reflektert praksis og læring for lærere (Utdanningsdirektoratet, 2019). Dette kapittelet har vist hvordan to ulike forskningsdesign gir komplementerende måter å studere slik praksis, spesielt når det gjelder å forstå hva som kjennetegner en læringsfremmende vurderingspraksis som en integrert del av læreres undervisningspraksis. Vi har spesielt trukket fram eksempler når det gjelder hvordan lærere gir fortløpende skriftlige og muntlige tilbakemeldinger i fagene norsk og matematikk.

TALIS-undersøkelsen skiller på noen måter mellom undervisningspraksis og vurderingspraksis, men har også elementer som knytter disse 
sammen, slik vi har vist. TALIS sier lite om kvaliteten på tilbakemeldinger lærere gir sine elever, men lar oss undersøke hyppigheten av tilbakemeldinger knyttet til læreres konkrete undervisningsfag og klasser. LISA-prosjektet har hatt som mål å undersøke både hyppighet og kvalitet på tilbakemeldinger i observerte klasserom, og kan dermed utfylle rom $\mathrm{i}$ kunnskapsfeltet om hva som kjennetegner læreres vurderingspraksis på ungdomstrinnet i Norge.

Funn fra TALIS 2018 viser at det har skjedd en forbedring ved flere sider av læreres vurderingspraksis siden TALIS 2013. Vi har imidlertid pekt på at det er noen forskjeller mellom læreres selvrapporteringer om vurderingsformer i norsk og matematikk i TALIS-materialet. Dette gjelder spesielt muntlig faglig feedback, der det er en høyere andel lærere som underviser i norsk som observerer hvordan elevene jobber med bestemte oppgaver og gir dem tilbakemelding på det de gjør. Slik umiddelbar tilbakemelding kan være en viktig korreksjon eller pekepinn på om elevene er på «feil spor» i forhold til læringsmålet.

Det norske tillegget til TALIS-undersøkelsen viser også at det kunne vært langt flere lærere som sjekket at tilbakemeldinger de gir på skriftlige oppgaver blir forstått av elevene. Dette gjelder spesielt i matematikkfaget, selv om vi har påpekt at det kan være noen naturlige forskjeller mellom disse to fagene når det gjelder hvilke didaktiske valg lærere tar. Funn fra LISA-prosjektet indikerer at det innen begge fag er forholdsvis lav kvalitet på tilbakemeldingene, når disse vurderes av forskere som observerer etter gitte kriterier basert på oppdatert forskningsbasert kunnskap. LISAeksemplet som er tatt med her viser også at det er ganske få lærere som står for en stor del av de tilbakemeldinger som har høy kvalitet. Dette indikerer at det er stort potensiale for å jobbe kollektivt videre med dette tema både i den første lærerutdanningen og som del av en godt ledet livslang læring for lærere.

\section{Referanser}

Ball, D. L. \& Cohen, D. K. (1999). Developing practice, developing practitioners:

Toward a practice-based theory of professional education. I G. Sykes \& L.

Darling-Hammond (Red.), Teaching as the learning profession: Handbook of policy and practice (s. 3-32). Jossey Bass. 
Black, P. \& Wiliam, D. (1998). Inside the black box. Raising standards through classroom assessment. King's College London.

Carlsten, T. C. (2021). Profesjonelle fellesskap på ungdomstrinnet: Om spørsmål og svar i TALIS 2018. (I denne boken).

Carlsten, T. C., Björnsson, J. K. \& Throndsen, I. (2021). Hovedfunn fra TALIS 2018-undersøkelsen. (I denne boken).

Caspersen, J., Aamodt, P. O., Vibe, N. \& Carlsten, T. C. (2014). Kompetanse og praksis blant norske loerere: Resultater fra TALIS-undersøkelsen i 2013 (NIFU-rapport 41/2014). Nordisk institutt for studier av innovasjon, forskning og utdanning. https://www.nifu.no/publications/1173469/

Dalland, C. \& Klette, K. (2014). Work-plan heroes: Student strategies in lowersecondary Norwegian classrooms. Scandinavian Journal of Educational Research, 58(4), 400-423. https://doi.org/10.1080/00313831.2012.739200

Dåsvatn, M. N. (2016). Muntlige tilbakemeldinger i norskfaget. En videostudie av fem klasserom [Masteroppgave, Universitetet i Oslo]. DUO vitenarkiv. http://urn. nb.no/URN:NBN:no-5566o

Forskrift til opplæringslova. (2006). Forskrift til opploeringslova (FOR-2006-06-23724). Lovdata. https://lovdata.no/forskrift/2006-06-23-724

Grossman, P. (2010). PLATO manual. http://cset.stanford.edu/media/PLATO_ Overview.pdf

Grossman, P., Loeb, S., Cohen, J., Hammerness, K., Wyckoff, J. Boyd, D. \& Lankford, H. (2010). Measure for measure: The relationship between measures of instructional practices in middle school English Language Arts and teachers' value added scores (Working Paper 16015). National Bureau of Economic Research. https://doi. org/10.3386/w16015

Grossman, P. \& McDonald, M. (2008). Back to the future: Directions for research in teaching. American Educational Research Journal, 45(1), 184-205. https://doi. org/10.3102/ooo2831207312906

Grossman, P., Loeb, S., Cohen, J. \& Wyckoff, J. (2013). Measure for measure: The relationship between measures of instructional practice in middle school English language arts and teachers' value-added scores. American Journal of Education, 119(3). https://doi.org/10.1086/669901

Harlen, W. (2007). Criteria for evaluating systems for assessment. Studies in Educational Evaluation, 33(1), 15-28. https://doi.org/10.1016/j.stueduc.2007.01.003

Hattie, J. (2009). Visible learning. A synthesis of over 800 meta-analyses relating to achievement. Routledge.

Hattie, J. \& Timperley, H. (2007). The power of feedback. Review of Educational Research, 22(1), 81-112. https://doi.org/10.3102/003465430298487

Hiebert, J., Gallimore, R. \& Stiegler, J. W. (2002). A knowledge base for the teaching profession: What would it look like and how can we get one? Educational Researcher, 31(5), 3-15. https://doi.org/10.3102/0013189X031005003 
Hiebert, J. \& Stigler, J. W. (2000). A proposal for improving classroom teaching: Lessons from the TIMSS Study. The Elementary School Journal, 101(1), 3-20. https://doi.org/10.1086/499656

Hill, H. C., Blunk, M., Charalambous, C., Lewis, J., Phelps, G. C., Sleep, L. \& Ball, D. L. (2008). Mathematical knowledge for teaching and the mathematical quality of instruction: An exploratory study. Cognition and Instruction, 26(4), 430-511. https://doi.org/10.1080/07370000802177235

Klette, K. (2003). Lærernes klasseromsarbeid; Interaksjons- og arbeidsformer i norske klasserom etter Reform 97. I K. Klette (Red.), Klasserommets praksisformer etter Reform 97 (s. 39-76). Pedagogisk forskningsinstitutt.

Klette, K. (2018). A new generation classroom studies. I C. Osbeck, Å. Ingerman \& S. Claesson (Red.), Didactic classroom studies: A potential research direction (s. 225-243). Nordic Academic Press.

Klette, K., Blikstad-Balas, M. \& Roe, A. (2017). Linking instruction and student achievement: Research design for a new generation of classroom studies. Acta Didactica Norge, 11(3). https://doi.org/10.5617/adno.4729

Klette, K. \& Carlsten, T. C. (2012). Knowledge in teacher learning: New professional challenges. I K. Jensen, L. C. Lahn \& M. Nerland (Red.), Professional learning in the knowledge society. Sense Publishers.

Kunnskapsdepartementet. (2017). Verdier og prinsipper for grunnopploeringen overordnet del av loereplanverket. Regjeringen. https://www.regjeringen.no/no/ dokumenter/verdier-og-prinsipper-for-grunnopplaringen/id2570003/

Larsen, E. H., Vaagland, K. \& Federici, R. A. (2017). Vurdering for loering. Resultater og analyser av skoler og skoleeieres svar på spørsmål om vurderingspraksis (NIFUrapport 2017:24). NIFU. https://www.nifu.no/publications/1504830/

Meld. St. 22 (2010-2011). Motivasjon - Mestring - Muligheter. Kunnskapsdepartementet. https://www.regjeringen.no/no/dokumenter/meldst-22-2010--2011/id641251/

Meld. St. 20 (2012-2013) På rett vei. Kunnskapsdepartementet. https://www. regjeringen.no/no/dokumenter/meld-st-20-20122013/id717308/

Meld. St. 28 (2015-2016). Fag - Fordypning - Forståelse - En fornyelse av Kunnskapsløftet. Kunnskapsdepartementet. https://www.regjeringen.no/no/ dokumenter/meld.-st.-28-20152016/id2483955/

Nasjonalt kompetansemiljø i vurdering. (2012). Teoretisk bakgrunnsdokument for arbeid med vurdering for loering på ungdomstrinnet. https://www.udir. no/globalassets/upload/ungdomstrinnet/rammeverk/ungdomstrinnet_ bakgrunnsdokument_vurdering_for_laring_vedlegg_5.pdf

OECD/CERI. (2005). Formative assessment. Improving learning in secondary classrooms. OECD. 
Scriven, M. (1967). The methodology of evaluation. I R. Tyler, R. Gagné \& M. Scriven (Red.), Perspectives of curriculum evaluation (s. 39-83). Rand McNally.

Seidel, T. \& Shavelson, R. J. (2007). Teaching effectiveness research in the past decade: The role of theory and research design in disentangling metaanalysis results. Review of Educational Research, 77(4), 454-499. https://doi. org/10.3102/0034654307310317

St.meld. nr. 16 (2006-2007)....og ingen sto igjen. Tidlig innsats for livslang loering. Kunnskapsdepartementet. https://www.regjeringen.no/no/dokumenter/stmeldnr-16-2006-2007-/id441395/

Stobart, G. (2008). Testing times: The uses and abuses of assessment. Taylor and Francis. https://doi.org/10.4324/9780203930502

Throndsen, I., Hopfenbeck, T. N., Lie, S. \& Dale, E. L. (2009). Bedre vurdering for loring - Rapport fra «Evaluering av modeller for kjennetegn på måloppnåelse $i$ fag». Det utdanningsvitenskaplige fakultet, Universitetet i Oslo.

Throndsen, I., Carlsten, T. C. \& Björnsson, J. K. (2019). TALIS 2018 - Første hovedfunn fra ungdomstrinnet. Institutt for lærerutdanning og skoleforskning, Universitetet i Oslo. http://hdl.handle.net/11250/2601320

Timperley, H. \& Alton-Lee, A. (2008). Reframing teacher professional learning. Review of Research in Education, 32(1), 328-369. https://doi. org/10.3102/0091732X07308968

Utdanningsdirektoratet. (2019). Erfaringer fra nasjonal satsing på vurdering for loering (2010-2018). https://www.udir.no/tall-og-forskning/finn-forskning/rapporter/ erfaringer-fra-nasjonal-satsing-pa-vurdering-for-laring-2010-2018/4.-fortsattbehov-for-a-videreutvikle-praksis/

Vibe, N., Aamodt, P. O. \& Carlsten, T. C. (2009). Å vere ungdomsskoleloerer i Norge: Resultater fra OECDs internasjonale studie av undervisning og loering (TALIS) (NIFU-rapport 2009:23). Nordisk institutt for studier av innovasjon, forskning og utdanning. https://www.nifu.no/publications/970351/

Wiliam, D. (2010). The role of formative assessment in effective learning environments. I H. Dumont, D. Istance \& F. Benavides (Red.), The nature of learning. Using research to inspire practice. OECD Publishing. https://dx.doi. org/10.1787/9789264086487-en 



\section{Forfatterbiografier}

Julius K. Björnsson er forsker ved Institutt for lærerutdanning og skoleforskning og leder av Enhet for kvantitative utdanningsanalyser (EKVA), Universitetet i Oslo. Han har lagt vekt på metode og psykometri, spesielt IRT-analyser av mange typer prøver og eksamener. Björnsson har arbeidet med internasjonale utdanningsstudier siden år 2000, vært prosjektleder for PISA og TALIS og ledet Islands evalueringsinstitutt med ansvar for nasjonale prøver og andre studier. Han har også vært involvert i den internasjonale styringen av PISA- og TALIS-studiene, og har i tillegg hatt ansvar for den psykometriske delen av de norske nasjonale prøvene, hvor han nå er ekstern kvalitetssikrer.

Sigrid Blömeke er professor og senterleder ved Centre for Educational Measurement (CEMO), Universitetet i Oslo. Ho var tidligere professor ved Humboldt-universitetet (Berlin), Michigan State University og Universitetet i Hamburg. Blömeke har doktorgrad i sosiologi og habilitasjon i utdanningsvitenskap. Hun forsker på lærerkompetanse og dens effekter på elevenes utvikling, var prosjektleder for TEDS-M og medlem av ekspertgruppa i TALIS. Blömeke har fått flere priser for framragende forskning, blant annet fra Universitetet i Oslo, det tyske vitenskapsselskapet for utdanningsforskning (GERA) og Universitetet i Paderborn, Tyskland.

Christian Brandmo er professor ved Institutt for spesialpedagogikk ved Universitetet i Oslo. Foruten fokus på kvantitative forskningsmetoder er hans forskningsinteresser knyttet til motivasjons- og læreprosesser hos elever, lærere og skoleledere. Gjennom de siste ti årene har han publisert en rekke artikler og kapitler om skoleledelse samt motivasjon hos lærere og elever, og blant annet bidratt med et kapittel i boken Global perspectives on teacher motivation (Cambridge University Press, 2017). Brandmo 
leder for tiden den kvantitative delen av prosjektet EVA2020 som evaluerer den nye læreplanen, fagfornyelsen.

Tone Cecilie Carlsten var ansatt som utdanningsforsker ved Nordisk institutt for studier av innovasjon, forskning og utdanning (NIFU) 2006-2020. Hennes ekspertise er strategisk kompetanseledelse i profesjoner, med vekt på sammenhenger mellom policy og praksis. På bakgrunn av det langvarige arbeidet med TALIS 2008, 2013 og 2018 i Norge har hun også vært invitert til den internasjonale TALIS-gruppen ved Directorate for Education and Skills i OECD. Carlsten er utdannet allmennlærer og har fullført doktorgradsutdanning ved Det utdanningsvitenskapelige fakultet ved Universitetet i Oslo, med forskningsopphold ved Stanford University. I dette arbeidet inngikk videostudier av klasseromsundervisning, og praktisk bruk av data fra slik forskning i utvikling av læreres profesjonsfellesskap.

Eyvind Elstad er professor ved Institutt for lærerutdanning og skoleutvikling, Universitetet i Oslo. Hans forskning har i de siste årene dreid seg i stor grad om utdanningssystemer i nordiske land, styring og ledelse i utdanningssektoren, bruk av digital teknologi i skolen samt lærerutdanning spesielt (blant annet bruk av veiledningsverktøy i lærerutdanningens praksisperioder). Hovedtyngden i hans undervisning har i de seneste årene vært forskningsmetoder og forskningsdesign i masterprogrammet i utdanningsledelse.

Greta Björk Gudmundsdottir er professor i pedagogikk ved Institutt for lærerutdanning og skoleforskning, Universitetet i Oslo. Som professor på $\mathrm{UiO}$ og forsker på Senter for IKT i utdanningen har Gudmundsdottir forsket på digital teknologi i skolen og i lærerutdanningen. Hun er spesielt opptatt av digital dømmekraft hos elever og lærerstudenter, samt utviklingen av lærerens profesjonsfaglige digitale kompetanse (PfDK). Gudmundsdottir har publisert nasjonalt og internasjonalt og er blant annet i prosjektgruppen til den internasjonale Computer and Information Literacy-studien (ICILS), Horizon 2020 Digital Generation (DigiGen) og Erasmus+ Developing ICT in Teacher Education (DICTE). 
Kirsti Klette er professor ved Institutt for lærerutdanning og skoleforskning, Universitetet i Oslo. Klettes forskningsinteresser ligger innenfor temaene reformpolitikk, lærerarbeid og studier av undervisning og læring i klasserommet. Klette har ledet flere større nasjonale, nordiske og internasjonale forskningsprosjekter der hun har undersøkt hvordan, og i hvilken grad, utdanningsreformer får konsekvenser for undervisning og læring på klasseromsnivå. De siste årene har Klette særlig arbeidet med videodokumentasjon fra klasserommet, og hun har ledet flere nasjonale og internasjonale anerkjente videostudier. Klette er videre leder for Nordic Center of Excellence: Quality in Nordic Teaching (QUINT) en ny satsing for komparativ nordisk klasseromsforskning.

Trude Nilsen er seniorforsker ved Institutt for lærerutdanning og skoleforskning, Universitetet i Oslo. Nilsen har forsket på læreres kompetanse og undervisning, skolemiljø og likeverd. Hun forsker spesielt på data fra internasjonale storskala-undersøkelser, og er opptatt av psykometri og anvendt metode. Nilsen har publisert nasjonalt og internasjonalt og er prosjektleder av prosjektet Teachers' Effect on Student Outcomes (TESO) finansiert av Norsk Forskningsråd, er med i prosjektet Trends In Mathematics and Science Study (TIMSS) og i de internasjonale ekspertgruppene til TIMSS og TALIS. Hun er også leder av forskergruppen Large-scale Educational Assessment (LEA).

Ronny Scherer er professor ved Centre for Educational Measurement (CEMO), Universitetet i Oslo. Han forsker på kvantitative metoder og pedagogiske målinger. Som professor ved CEMO er Scherer spesielt opptatt av analyser av storskaladata, metaanalyser, psykometri og digital teknologi i skolen og i lærerutdanningen. Scherer har publisert nasjonalt og internasjonalt og er blant annet i prosjektgruppen til ICILS og i ekspertgruppen til PIAAC og TALIS.

Inger Throndsen var nasjonal prosjektleder for TALIS 2018. Hun var ansatt som forsker ved Institutt for lærerutdanning og skoleforskning, Universitetet i Oslo, fram til høsten 2019. Throndsen har vært involvert i både nasjonale og internasjonale undersøkelser rettet mot skolesektoren. Hun var prosjektleder for ICILS 2013 (International Computer and 
Information Literacy Study) og ledet evalueringen av Utdanningsdirektoratets prosjekt «Bedre vurderingspraksis». Hun har mange års erfaring fra skolen og har arbeidet både som lærer, pedagogisk veileder og skoleleder.

Dijana Tiplic er professor i utdanningsledelse ved Institutt for lærerutdanning og skoleforskning, Universitetet i Oslo. Tiplics forskningsområder inkluderer motivasjonsaspekter i skolen, erfaringsbasert læring og strategiske endringer i høyere utdanning. Hun er spesielt opptatt av hvordan organisatoriske faktorer påvirker blant annet jobbmotivasjon hos lærere og skoleledere. Hun var en del av en internasjonal undersøkelse av hvordan lærebøker påvirkes av globalisering og multikulturalisme. Tiplic har publisert internasjonalt, blant annet i Scandinavian Journal of Educational Research, Higher Education, Cambridge Journal of Education, International Journal of Leadership in Education og European Education. 